\title{
Measuring the presence of organized crime across Italian provinces: a sensitivity analysis
}

\section{Giovanni Bernardo ${ }^{1} \cdot$ Irene Brunetti $^{2} \cdot$ Mehmet Pinar $^{3}$ (D) $\cdot$ Thanasis Stengos $^{4}$}

Accepted: 17 November 2020 / Published online: 30 November 2020

(c) The Author(s) 2020

\begin{abstract}
The existing literature identifies different indicators to construct organized crime indices and places equal importance to different concepts of organized crime. This paper examines the sensitivity of organized crime across Italian provinces when different set of indicators and weights are used to combine crime indicators. Our findings suggest that there is a remarkable variation in the distribution of organized crime across Italian provinces based on the choice of indicators and the importance given to different crime indicators. It is also found that the relationship of organized crime with socioeconomic and political factors varies depending on the normative choices made in the construction of an organized crime index.
\end{abstract}

Keywords Organized crime $\cdot$ Composite index $\cdot$ Italian provinces $\cdot$ Mafia $\cdot$ Stochastic dominance

JEL Classification $\mathrm{C} 12 \cdot \mathrm{C} 14 \cdot \mathrm{C} 15 \cdot \mathrm{K} 49 \cdot \mathrm{R} 58$

Mehmet Pinar

mehmet.pinar@edgehill.ac.uk

Giovanni Bernardo

giovanni.bernardo@unipa.it

Irene Brunetti

i.brunetti@inapp.org

Thanasis Stengos

tstengos@uoguelph.ca

1 Department of Law, University of Palermo, Palermo, Italy

2 National Institute for Public Policies Analysis, Rome, Italy

3 Business School, Edge Hill University, Ormskirk, Lancashire, UK

4 Department of Economics and Finance, University of Guelph, Guelph, Canada 


\section{Introduction}

Considering the interdependent links between organized crime and the political and socio-economic settings, the economic analysis of crime has grown to become an important research agenda (Gonzalez-Ruiz and Buscaglia 2002; Pinotti 2020). Organized crime has, in fact, extensive economic consequences: in the short term, violence and predatory activities destroy part of the physical and human capital stock; in the long run, the presence of criminal organizations increases the riskiness and uncertainty of the business environment, which ultimately lowers the growth potential of the economy (Pinotti 2015a, b).

From a theoretical point of view, only a limited number of research papers examined the economics of organized crime. Becker's (1968) pioneering article shows that even individuals involved in illegal or criminal activities behave rationally. The idea of Becker's model is that a rational offender faces a gamble: the individual rationally decides whether or not to commit a crime by comparing benefits and costs of crime with those of alternative (legitimate) activities. Consequently, if the government enhances the probability and severity of punishment, crime becomes less attractive. The economic literature has also stressed welfare comparisons between monopoly and competitive supply of illegal activities. Buchanan (1973) argues that monopoly in the supply of illegal activities is socially desirable because of the output restriction, while Backhaus (1979) argues that passive approval in the monopolized syndication of crime should lead to an increase of illegal activities. There is relatively recent literature in economics that supports the former view since market competition should generate higher crime rates and corruption (Kugler et al. 2005), violence, and other negative externalities (Becker et al. 2006; Levitt and Venkathesh 2000). Most of the theoretical contributions focus on the conflict between criminal organizations and government agencies since they compete for control over the territory. For instance, Shelling (1971-1984a; 1984b) describes how an organized criminal group (such as the mafia) may be able to extort payments from firms to protect them from other criminals and enforcement of property rights. In this sense, the mafia can be seen as an alternative tax collector and provider of public goods taking the place of government (Alexeev et al. 2004). Dal Bó and Di Tella (2003) analyze how criminal organizations strategically use violence to manipulate elected politicians. Moreover, Dal Bó et al. (2006) present a model where a criminal group could influence public officers using both monetary incentives and self-enforceable punishments within a unified framework. Along this line, Alesina et al. (2019) analyze how organized crime could manipulate electoral results and politicians' behavior using pre-electoral violence.

From an empirical point of view, despite the lack of a common definition of organized crime and the complexity of the phenomenon, there have been several attempts to measure its presence and effect at the local, national, and international levels. Messner et al. (1999) and Anselin (2000) showed that the location of illegal activity could supply relevant insights into the exploration of crime dynamics. In this regard, Italian crime has particular qualitative and quantitative features. Crime 
activities vary across time and space, and organized crime, like Mafia, Camorra, 'Ndrangheta, has territorial roots in some southern regions (Marselli and Vannini 1997) and have spread to many other parts of the country (Buonanno and Pazzona 2014). Criminal activities in a given region could be considered as a good proxy for the socioeconomic development differences among regions. Relatedly, both Peri (2004) and Centorrino and Ofria (2008) showed how organized crime could influence both economic growth and the quality of local institutional systems. Pinotti (2015a) shows that in Southern Italy, the presence of mafia decreases GDP per capita by $16 \%$. Among the few macroeconomic studies which have provided a formalization of the impact of organized crime on income, Centorrino and Signorino $(1993,1997)$ estimate the impact of criminality on total fiscal revenues accounting also for the income not produced in the economy because of the mafia's presence. Their results suggest that, in Italy, the loss of revenues due to income not produced in the economy because of the mafia presence is equal to $0.7 \%$ of GDP. TorresPreciado et al. (2017) demonstrated that criminal activities (particularly homicides and robbery) hamper economic growth across Mexican states. Cracolici and Uberti (2009) investigated the relationship between crime and some socioeconomic variables for Italian provinces and found that the presence of foreigners and the level of young male unemployment are related to criminal activities. Battisti et al. (2020) provide evidence that organized crime is more prevalent in Italian regions in which inequality is high and social mobility is low.

Organized crime increases the risks for (and the costs of) investment because of possible attacks, intimidation, and the destruction of property. In this respect, Daniele and Marani (2011) demonstrated that the presence of organized crime is an obstacle for the attractiveness of the local economy leading to lower levels of foreign direct investment inflows. Lavezzi (2008) argued that organized crime also operates in the legal sector for money laundering and removing any trace of these crimes. Through money laundering, the criminal organizations employ the proceeds of crime in the legal economy, infiltrating mainly the traditional manufacturing sectors characterized by small and medium firms that use low levels of technology and human capital (Capuano and Giacalone 2018). Besides, there is the lost fiscal revenue due to evasion induced by the same mafia presence (Daniele 2009). Ganau and Rodríguez-Pose (2018) showed that organized crime has a direct negative effect on agglomeration and clustering of small and medium-sized enterprises hampering its productivity growth. Fabrizi et al. (2019) and Calamunci and Drago (2020) demonstrated that when a criminal firm is eliminated from a relevant market, the performance of non-criminal competitors significantly increases both in terms of efficiency and turnover. Looking at the housing sector, Battisti et al. (2019) show that mafia homicides have a negative and significant impact on house prices while Boeri et al. (2019) unveil a positive effect of re-allocations of confiscated real estate assets.

Another strand of literature investigates the relation between the presence of organized crime and politics. This literature examines the impact of organized crime on democratic governance, which is fulfilled by the manipulation of the electoral outcomes (Acemoglu et al. 2013; Daniele and Geys 2015). Along this line, Daniele and Dipoppa (2017) analyzed how organized crime manipulates electoral outcomes using violence. Moreover, De Feo and De Luca (2017) showed that mafia obtained 
economic advantages in exchange for its electoral support while Di Cataldo and Mastrorocco (2020) revealed that local governments infiltrated by criminal organization spent more for the construction sector and waste management than in other areas of public utility. Given the negative consequences of illegal activities on regional socioeconomic development, policymakers placed a growing emphasis on the measurement of organized crime to help them understand the crime patterns and trends.

From the measurement point of view, as highlighted by Savona et al. (2012), quantifying and understanding organized crime is complex because of the high number of dimensions that should be taken into consideration. However, the measurement of organized crime (e.g., in the forms of indices) should be addressed to investigate its impact and to provide policy recommendations to mitigate its negative effects (Sansò-Rubert Pascual 2017). Henceforth, to track organised crime and to examine its effect on socioeconomic factors, construction of composite organised crime indices have become popular (see e.g. Calderoni 2011; Dugato et al. 2014, 2020). There are many judgement calls to be made while constructing an organised crime index such as the selection of crime types, weight allocation across crime types and so on (see OECD 2008 for detailed procedures on the construction of indices). This paper focuses on the choice of weights given to each crime indicator. It should be noted that even though the crime distribution does not change with the allocation of different weights on the crime indicators, policymakers still choose weights to obtain a single composite crime measure with an overall spatial and temporal variation in organised crime. In this paper, we obtain weights of crime variables that lead to the highest and lowest measured organised crime across Italian provinces with the use of stochastic dominance efficiency (SDE) methodology. Obtaining the highest and lowest measured organised crime outcomes across provinces is particularly important as this leads to a feasible range of organised crime, useful to policymakers as it allows them to assess the sensitivity of the organised crime measures to alternative weight choices. Furthermore, it would offer them a feasible range of organised crime outcomes for Italian provinces irrespective of the importance (weight) attached to a given crime indicator. Since there is no theoretical reason to believe that one crime indicator is more important than any other, rather than obtaining indices based on alternative weights and the potential manipulation of such indices based on weight choices, this paper offers a feasible range of an organised crime index with the use of the SDE methodology. In short, irrespective of the importance (weight) attached to different crime indicators, the organised crime index for a given region would lie between a minimum and maximum organized crime outcome obtained with our approach.

The previous literature used different set of methodologies to obtain organised crime variables (indices). For instance, the empirical literature using organised crime variables to assess its effect on socioeconomic variables usually aggregates different set of indicators (see e.g., Daniele and Marani 2011; Neanidis et al. 2017) or obtains equally-weighted organised crime indices (e.g., see e.g. Calderoni 2011; Dugato et al. 2014). Using equal weights implies that all the crime indicators used in the analysis have the same importance (Decancq and Lugo 2013; Greco et al. 2019). Furthermore, it has been argued that if the variables are highly and positively correlated, any index constructed by using these variables would be redundant (see e.g., McGillivray 2005; Foster et al. 2013 among many 
others that examine the redundancy of the HDI by using correlation analysis) as using indicators that are highly and positively correlated leads to a 'double counting' problem (OECD 2008). In that respect, Calderoni (2011) using correlation analysis to identify the set of crime variables that are positively associated with the mafia-related crime variables as part of a composite index, faces the above problem of 'double counting'. Hence, using correlation analysis to identify the indicators to be included in the construction of a composite index leads to certain measurement flaws. Another popular method that is used to obtain composite indices is principal component analysis (see e.g., Ogwang and Abdou 2003; Singh et al. 2012; Smits and Steendijk 2015; Dugato et al. 2020). The idea behind principal component analysis is to capture the highest variation possible in the original variables with as few variables as possible (Ram 1982). In that case, this method aims to combine indicators that construct the index with weights that are more 'objective' by overcoming the arbitrary weight choices of policymakers (Ray 2008). However, principal component analysis only considers second moments of the variables after standardizing for a common mean. This would be adequate if the data were characterized solely by the first two moments, but this is usually not the case for most of the variables used in empirical work.

More importantly, constructing an index based on equal weights, correlation analysis or principal component analysis may produce a composite organised crime index that gives the impression that the situation is "not that bad" or it is "extremely bad". For instance, inclusion of a variable that is positively correlated with mafia-related crimes (via correlation analysis) or explains sufficient variation in the overall data (via principal component analysis) could result to lower or higher measured organised crime. Henceforth to avoid the potential effect of the choice of variables and weights given to the indicators, which would be ignored by existing methods, the methodology used in this paper allows us to obtain weights that would result in highest and lowest measured organised crime across Italian provinces and would offer a feasible range of organised crime outcomes for all provinces considered irrespective of the weight choices. Our study aims to provide a statistical construction of a feasible range of organised crime outcomes across Italian provinces by avoiding the arbitrariness of indicator and variable choices. In Italy, indeed, organized crime is a long-lasting phenomenon, and criminal organizations have a pervasive control over the territory allowing criminal groups to engage in complex criminal activities (e.g., smuggling and drug-trafficking) as well as threatening local politicians and public officials. Moreover, the widespread presence of criminal organizations in southern regions has affected its socioeconomic environment (Pinotti 2015a; Acemoglu et al. 2020) which partially explains Italy's long-term regional differences (Felice 2018). Despite the relevance of organized crime for Italy, there are only two measures of organized crime indices: the index computed by the Italian National Institute of Statistics (ISTAT) and the mapping realized by MA.CR.O. (MAppatura CRiminalità Organizzata) Project. Therefore, there is a need for a systematic analysis of the sensitivity of organised crime across Italian provinces based on the normative choices, and the relevance of measurement of organised crime for the socio-economic development.

Our paper offers several insights. First, we examine the sensitivity of organized crime across Italian provinces based on the indicator choice and importance 
attached to the chosen indicators. Second, we provide a measurement of the phenomenon in Italy at a province-level highlighting the geographic differences in organized crime. Third, rather than relying on normative judgment calls to obtain an organized crime index we obtain weights for each crime variable that leads to the worst and best measured organized crime index (highlighting the variation of organized crime based on weight choices) with the use of the SDE methodology. Most of the existing literature obtain organized crime indices either by summing different crime variables or assigning equal weights to them, suggesting that each type of crime is given equal importance. Fourth, based on the proposed two extreme case indices, we discuss which type of crime indicators would require national and/or local policies and also examine the relationships of various organized crime indices with other socio-economic variables.

This paper is organized as follows. Section 2 provides the detailed stages for the construction of organized crime index, detailed literature on the way that organized crime is measured, and offers the data used in this paper. Section 3 provides the SDE methodology used to obtain a combination of different concepts of organized crime for 103 Italian provinces. Section 4 provides the results obtained with the SDE methodology, and finally, Sect. 5 concludes.

\section{Construction of organized crime index}

Constructing any multidimensional (multivariate) index is a non-trivial task. OECD (2008) offers the detailed steps on how to construct composite indicators (indexes), which requires the following steps: (1) the definition of the concept to be measured, (2) selection of the indicators, (3) normalization of the indicators, and (4) the choice of the aggregation method to put these indicators together to obtain the composite index.

To carry out the steps mentioned above, this section is organized as follows. In Sect. 2.1, we first provide a detailed literature review on how organized crime is measured by the existing literature, which would guide us about the set of indicators that we can utilize to construct an organized crime index. Section 2.2 introduces the data set used in this paper. Then Sect. 2.3 provides the normalization procedure used to convert each variable before the aggregation, and finally, Sect. 2.4 provides the aggregation methodologies used by the previous literature to combine the set of variables to obtain organized crime index.

\subsection{Literature}

There has been an increasing strand of literature that examines the relationship between organized crime and socio-economic and political factors. Table 1 presents a summary of the most relevant literature that describes the measurement of organized crime and the main findings.

For measuring organized crime, some papers use indices computed as the sum of different sets of crime variables (see e.g., Daniele and Marani 2011; Ganau and Rodríguez-Pose 2018; Neanidis et al. 2017; Pinotti 2015a, b among many others). Others, 







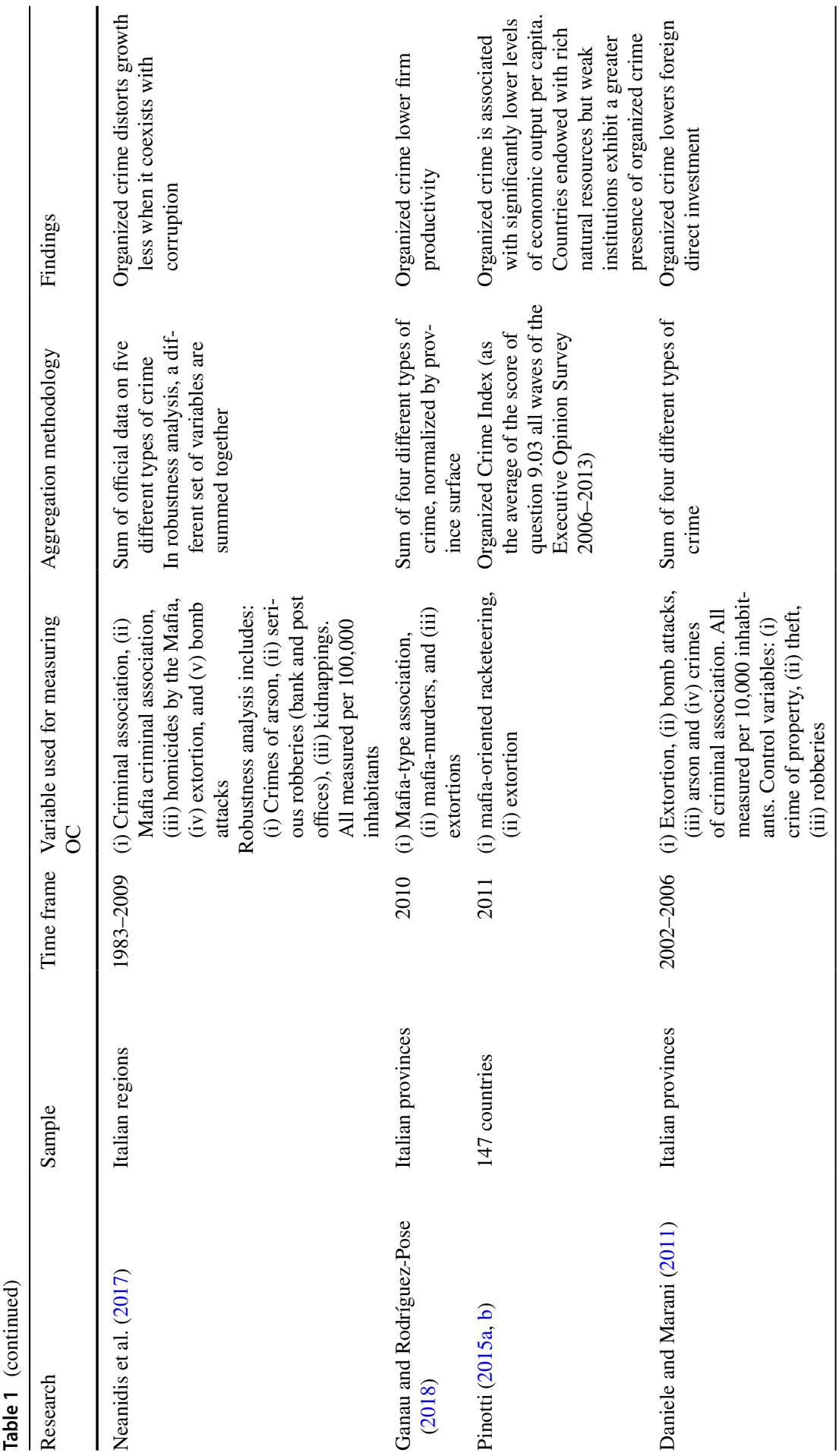









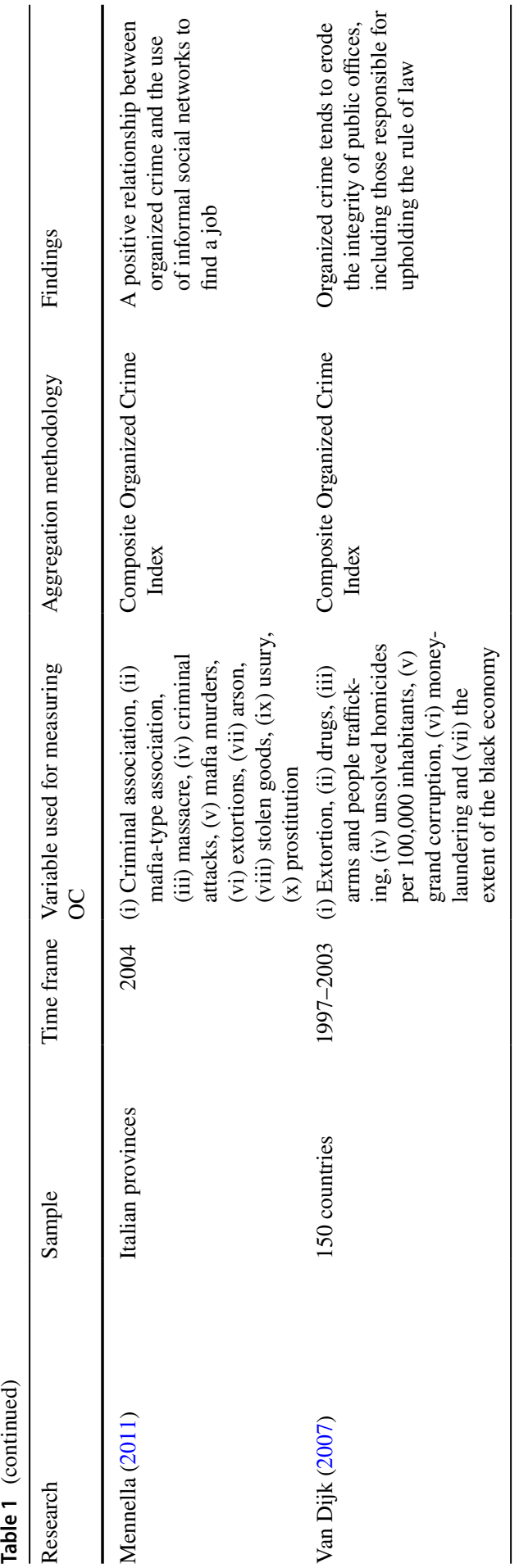


instead, employ a composite index. Composite indicators are indeed increasingly used both by researchers and by law enforcement agencies. For example, the so-called 'Composite Organized Crime Index' proposed by van Dijk (2007) combines data on the perceived prevalence of organized crime in the country. Regarding Italy, ISTAT (2010) provides an Organized Crime Index (OCI) that measures regional trends on the presence of mafia in Italy even though this index does not allow for regional comparisons (see also Caglayan et al. 2018; Calderoni 2011; Dugato et al. 2020 for construction of organized crime indices for Italian municipalities and provinces). Even though some literature on organized crime attempts to measure organized crime using factor analysis (Caglayan et al. 2018; Dugato et al. 2020), neither of the existing literature examined the extent to which organized crime may vary due to alternative indicator and weight choices, which is the aim of this paper.

\subsection{Variables}

Organized crime is extremely complex, for this reason there several definitions of this phenomenon derived from different epistemological perspectives as well as the analysis of criminal codes and case studies. After a systematic literature review, Albanese (2015) suggests two primary categories of illegal behaviour that reflect the individual crimes associated with organized crime activity, namely the provision of illicit services and goods and the infiltration of legitimate business or government. The first category represents the main source of income for criminal organizations, since the supply of goods or services prohibited by law allows criminal organizations to acquire monopoly control of certain illegal major market. Specific offences in this category include for instance drug trafficking, smuggling of migrants or usury. The second category, infiltration in legitimate business and government, represents a way to obtain a dominant position in the local economy as well as institutional level. Profits that come from black market activities are invested into legal business by strengthening the presence of criminal organizations within the territory. These proceedings are used to corrupt public officials both at the local and state level to provoke political instability and to protect organized criminal groups from law enforcement (Rose-Ackerman and Palifka 2018). As suggested by Calderoni (2014), we can expand the analysis including a third category, which is the "use of violence, threat or intimidation", that gathers offenses aiming to control, directly or indirectly, politics and local enterprise network. Specific offences in this category include for instance extortion to employers or employees, vandalism or violent attacks against politicians, journalists and law enforcement agencies. Finally, to emphasize the dimension of criminal conspiracy, we can also include types of criminal activities that occur when two or more persons agree to constitute a criminal association with the aim to perpetuate their criminal schemes over time. As suggested by Dugato et al. (2020), the number of criminal or mafia association help us to quantify the presence of organized crime within the territory.

Composite indices consists of sub-groups that are clustered under different themes that consist of different set of indicators that are measuring similar theoretical concepts (see OECD 2008 for detailed explanation on this). For instance, the 
FEEM sustainability index is conceptually divided into three concepts of sustainability (economic, social and environmental sustainability), which covers different set of indicators under the general themes (see Carraro et al. 2013; Pinar et al. 2014 for the details). Similarly, the Environmental Performance Index also consists of different indicators under main themes such as air quality, biodiversity and habitat where different set of indicators under each theme that are related to the concept is listed (see Wendling et al. 2020). In this paper, we follow a similar approach to cluster indicators under four main themes which we discussed at the beginning of this section: (1) Criminal conspiracy; (2) Provision of illicit goods and services; (3) Use of violence, threat or intimidation; (4) Infiltration of legitimate business or Government. Table 2 lists the four dimensions previously discussed, the indicators identified within each area for the Italian provinces and the respective definitions.

We only consider the period between 2004 and 2014 as the system of crime data collection changed in 2004 when a new database of the Italian Ministry of Interior called Investigation System ("Sistema di Indagine"-SDI) was established. In particular, the Investigation System allows all police forces to report a wide range of information about each crime such as type of offense, victim's details, geo-location of the crime. All this information is then inserted in a centralized database thereby avoiding both loss of data and possible cases of double counting. Hence, we use the series started in 2004 with the introduction of the SDI to avoid potential inconsistencies with the previous series (Ministry of Interior, Rapporto sulla criminalità e la Sicurezza in Italia 2007). ${ }^{1}$

Some offenses are connected with organized crime activities by definition, for example, mafia-type and criminal associations, mafia murders, councils dissolved due to mafia infiltration, and assets confiscated from organized crime. Other variables need a brief discussion to understand how and why they should be used to construct an organized crime index.

Starting with the "provision of illicit goods and services" dimension, Catino (2014) suggests that drug trafficking and usury can be seen as the core business of criminal organizations since these activities ensure high levels of profits. Moreover, Mennella (2011) expands the analysis to include those offenses which are related to prostitution and the handling of stolen goods. Turning the discussion to the use of "violence, threat or intimidation" dimension, we can observe that extortion is widely recognized as one of the most relevant activities of criminal associations (see e.g., Pinotti 2015a, b; Ganau and Rodríguez-Pose 2018). Daniele and Marani (2011) and Calderoni (2011) also argue that the presence of criminal organizations within the territory can be detected when arson, damage, kidnapping and criminal attack-type of offenses are observed. To conclude the discussion, Van Dijk (2007) recommends the inclusion of money-laundering and corruption-related offenses since the former facilitates penetration of the legitimate economy while the latter type of offenses increases the power of criminal groups over the relevant economic activity.

To allow for comparability across different provinces, we standardize each type of crime variable with the population of a given province. Each respective crime variable

\footnotetext{
${ }^{1}$ We exclude the bombing/incendiary attacks, bank/postal robbery, smuggling and track robbery variables from our analysis as these variables have some missing information for some years between 2004 and 2014. Since SDE methodology relies on balanced data, inclusion of these variables would limit the period of analysis and number of observations..
} 





Table 3 Descriptive statistics

\begin{tabular}{lrrrrr}
\hline Variable & \multicolumn{1}{c}{ Mean } & Median & SD & \multicolumn{1}{c}{ Min } & Max \\
\hline Mafia murders & 0.95 & 0.00 & 3.66 & 0.00 & 46.23 \\
Mafia type association & 1.44 & 0.00 & 4.16 & 0.00 & 59.12 \\
Councils dissolved & 0.42 & 0.00 & 2.43 & 0.00 & 36.39 \\
Assets confiscated & 6.41 & 0.00 & 23.08 & 0.00 & 384.05 \\
Extortion & 101.64 & 92.81 & 49.69 & 6.97 & 386.00 \\
Kidnapping & 23.89 & 22.42 & 13.36 & 0.00 & 97.35 \\
Criminal association & 15.75 & 11.89 & 18.80 & 0.00 & 311.01 \\
Arson & 223.35 & 151.42 & 220.53 & 11.94 & 1850.34 \\
Drugs & 529.36 & 484.69 & 241.69 & 43.54 & 2043.58 \\
Prostitution & 23.67 & 19.15 & 19.44 & 0.00 & 153.24 \\
Fraud & 1771.21 & 1692.65 & 598.17 & 189.06 & 4775.84 \\
Usury & 6.48 & 5.09 & 6.41 & 0.00 & 77.63 \\
Criminal attack & 7.69 & 5.60 & 9.22 & 0.00 & 117.26 \\
Threat & 1481.11 & 1408.44 & 503.59 & 0.00 & 3842.53 \\
Damage & 5719.02 & 5056.42 & 2842.88 & 612.95 & $25,310.09$ \\
Money laundering & 20.01 & 14.13 & 21.54 & 0.00 & 284.25 \\
Corruption & 4.78 & 3.46 & 5.67 & 0.00 & 44.38 \\
\hline & & & & & \\
\hline
\end{tabular}

is measured by the official number of crimes per 1,000,000 and published by the Italian National Institute of Statistics (ISTAT). Table 3 presents descriptive statistics for each variable. As can be seen from this table, the presence of different types of criminal activity varies dramatically. For instance, on average (per year and province), there is more presence of damage, threats, fraud, drug-related criminal activities, yet the per population presence of mafia-related crime (mafia murders, mafia-type association, councils dissolved due to mafia infiltration, and total assets confiscated) and crimes associated with corruption, usury and criminal attack are relatively low.

The previous literature used correlation and/or factor analysis (see, e.g., Calderoni 2011; Dugato et al. 2020) to determine the set of variables to be included as part of the organized crime index. In short, correlation analysis is used to identify which variables are strongly related to offenses directly attributable to criminal organizations, namely mafia murders, mafia-type and criminal association, dissolution of city councils due to mafia infiltration and confiscated assets. When all provinces are used in the correlation analysis, extortion, kidnapping and arson type of criminal offenses are positively and significantly correlated with mafia-related crimes and criminal association (see Table 7 for the correlation matrix for correlation coefficients among variables when all provinces are considered), but the correlation coefficients among variables differ when different geographical clusters are used (see Table 8 for the categorization of provinces into geographical clusters, and Tables 9, 10 and 11 for correlation coefficients among crime variables when northern, central and southern provinces of Italy are used in the analysis, respectively).

We observe that the mafia-type crimes are not correlated with one another, and their correlation with other variables is also limited in the northern regions. In the 
central provinces of Italy, we observe that only two mafia-type criminal activities (i.e., mafia association and assets dissolved) are correlated with each other. On the other hand, mafia-type criminal activities are correlated with each other and with other variables in the southern regions. This result could be attributed to the fact that, while in the southern part of Italy, the power of mafias resides in their control and exploitation of territory and community, criminal groups modify their behaviors and modi operandi when operating outside their territory of origin. In particular, mafia clans use their immense assets to infiltrate the legitimate economy and to control illegal markets such as large-scale drug trafficking, prostitution and goods counterfeiting (Europol 2013). Furthermore, the types of illegal activities in which criminal groups are engaged and its intensity can vary across provinces and time for other reasons such changing of the local economic structure (Lavezzi 2008), the spread of anti-mafia values in the population (Battisti et al. 2018) or the implementation of new crime prevention and control strategies delivered by law enforcement agencies and the courts (UNODC 2010).

Overall, based on the variation in correlation coefficients among crime variables across geographical clusters, the construction of the organized crime index should not be based merely on correlation coefficients (see e.g., Calderoni 2011) and factor analysis (see e.g., Dugato et al. 2020). Hence, rather than relying on the correlation or factor analysis to determine the variables to be used in the construction of organized crime index, we obtain seven different organized crime indices based on the categorization of variables under different aspects of organized crime. In sum, we will use indicators that are clustered into four categories in Table 2 to construct organized crime indices. We will also provide three alternative organized crime indices based on the literature review that considers different sets of variables in their construction. Firstly, we use four types of mafia-related criminal activities (see e.g., Calderoni 2011; Dugato et al. 2020). Secondly, we use four types of mafia-related criminal activities and also include extortion, criminal association, arson and kidnapping variables (see e.g., Mennella 2011; Daniele and Marani 2011). Thirdly, we use four types of mafia-related criminal activities, and also include extortion, arson, usury, money-laundering, drug-trafficking and corruption since the last four types of criminal offenses have been proposed in the recent literature (Caglayan et al. 2018; Dugato et al. 2020; Neanidis et al. 2017). Hence, overall, we will examine the sensitivity of organized crime based on different indicator choices and as well as the weights attached to these indicators.

\subsection{Normalization procedure}

Since crime indicators are measured in different units (e.g., total assets confiscated due to crime or number of criminal activity) and each variable measures a different type of crime not comparable with others, we first normalize indicators before aggregation.

There are numerous methods of normalization such as standardization (or z-scores), rescaling (or min-max), and distance to reference points, and one can choose a specific normalization procedure depending on the problem at hand (see OECD 2008 for further discussion on the benefits and disadvantages of various normalization 
procedures). In this paper, we follow a normalization of each variable by assigning 100 to the province with the highest crime activity in a particular crime indicator, while other provinces' scores are calculated as a percentage to the province with the highest crime activity for each type of crime variable (see OECD (2008) for the details of the normalization used in this paper and Environmental Performance Index (Wendling et al. 2020) and the Academic Ranking of Worldwide Universities (ARWU) that used a similar method to standardize each variable). Therefore, the following formula is used to have all types of crime variables to range between 0 and 100:

$$
c_{i j}^{t}=\left[\frac{C_{i j}^{t}}{\max \left(C_{j}\right)}\right] \times 100
$$

where $c_{i j}^{t}$ and $C_{i j}^{t}$ are normalized and actual crime outcomes in province $i$ for a given indicator $j$ at a given time $t$, respectively. $\max \left(C_{j}\right)$ represents the maximum (or highest) criminal activity of a given type of crime indicator $j$ during the period of the comparison. This normalization procedure allows us to have comparisons across provinces and time. To avoid potential effects of large outliers in each indicator, we set the maximum value to the 95 th percentile of the distribution of a given crime variable. ${ }^{2}$

\subsection{Aggregation methodology}

Most of the composite indices are obtained by using weighted averages (see e.g., Human Development Index, Multidimensional Poverty Index, and so on). In the same lines, both Calderoni (2011) and Dugato et al. (2014) obtained composite organized crime indices by a weighted average of various types of criminal activity. On the other hand, most of the empirical papers that examine the effect of organized crime on different socio-economic characteristics also rely on aggregating different types of organized crime (see e.g., Daniele and Marani 2011; Neanidis et al. 2017 among many others), suggesting that either different types of criminal activity are assigned equal importance or different crime variables are assigned weights based on factor analysis (see e.g., Caglayan et al. 2018; Dugato et al. 2020). In sum, different types of normalized crime indicators are aggregated to obtain organized crime index (OCI) for all provinces as follows:

$$
O C I_{i}^{t}=\left(\sum_{j=1}^{m} w_{j} \times c_{i j}^{t}\right)
$$

where $w_{j}$ is the weight attached to a given type of crime variable $j, c_{i j}^{t}$ is the normalized crime indicator $j$ for province $i$ at time $t$.

The choice of weights depends on the importance attached to the particular type of crime by policymakers and/or researchers based on normative judgment or datadriven methodologies. Without any clear indication of the relative importance of each

\footnotetext{
${ }^{2}$ In other words, the maximum criminal activity of given type of crime indicator $j$ during the period of the comparison is taken as the 95th percentile of the distribution where the crime levels above this percentile is allocated a value of 100 .
} 
type of crime, the previous literature obtained organized crime indices by summing different crime variables or using equally-weighted averages of normalized crime indicators. Daniele and Marani (2011), for example, construct an organized crime as the sum of extortion, bomb attacks, arson and crimes of criminal association per 10,000 inhabitants. Moreover, they use other types of crime as control variables: the number of crimes against property, thefts and robberies. Neanidis et al. (2017) study the interactions between organized crime and corruption where they obtain an organized crime index by summing five types of variables: the number of criminal association, mafia association, homicides by the mafia, extortion, and bomb attacks. According to the second way of constructing an organized crime index, Calderoni (2011) and Dugato et al. (2014) first normalize each set of variables and then aggregate them by using equal weights. However, both of these two approaches assume that different concepts of organized crime (e.g., criminal association and arson type of criminal offense) to be equally-contributing to organized crime, something that may not be the case.

Hence, in this paper, rather than relying on a subjective allocation of weights to each factor contributing to organized crime, we apply SDE, a data-driven methodology, to obtain a combination of different factors that lead to higher and lower measured organized crime across Italian provinces when compared to the equally-weighted benchmark index. The construction of two extreme scenarios will enable the policymakers to examine the sensitivity of organized crime indices based on the alternative importance attached to crime variables. Furthermore, a combination of factors that leads to the highest (lowest) measured organized crime would enable one to highlight the factors that are more (less) present across different units considered. In other words, indicators contributing relatively more to the highest measured organized crime index would suggest that these crimes are more present across units and time, and hence would require nation-wide policies. However, indicators that contribute relatively more towards the lowest measured organized crime index would suggest that these organised crimes are observed less frequently and would require local action at the units where the criminal activities are observed.

\section{SDE methodology}

The SDE methodology is a direct extension of pair-wise stochastic dominance (SD) methodologies where full diversification is allowed (i.e., comparison of weighted organized crime distributions across provinces). Pair-wise SD is used to test a set of relations that may hold between distributions (e.g., comparison of distributions of two crime indicators across different provinces of Italy). On the other hand, in the case of full diversification (i.e., SDE methodology), the composite organized crime levels in Italian provinces with pre-determined weights (e.g., the organized crime index obtained with a vector of equal weights), are taken as a benchmark and tested against all possible composite indices produced with any possible weighting scheme allocated to different crime indicators.

The SDE methodology has become a popular methodology to construct indices based on the distribution of the variables. In a related literature in finance, a more 
general, multivariate problem is that of testing whether a given portfolio is stochastically efficient relative to all mixtures of a discrete set of alternatives (Post 2003; Kuosmanen 2004; Roman et al. 2006), while others address this problem with various proposed SDE tests (Post and Versijp 2007; Scaillet and Topaloglou 2010; Linton et al. 2014; Arvanitis and Topaloglou 2017; Fang and Post 2017; Post and Poti 2017). These SDE tests are used to examine the existence of alternative ways of combining assets that dominate the benchmark market or welfare index to obtain best- and worst-case scenarios of wellbeing (e.g., Pinar et al. 2013, 2015, 2017, 2019; Agliardi et al. 2015; Pinar 2015; Mehdi 2019) and risk indices (see e.g., Agliardi et al. 2012, 2014). For instance, Pinar et al. (2013) used SDE methodology to obtain the best-case scenario combination of dimensions of the Human Development Index (HDI), where a full diversification of weights of HDI dimensions were used to obtain the most optimistic measurement of HDI among countries. In this paper, we will use the SDE approach to obtain combinations of different types of organized crime variables that lead to the highest and lowest measured organized crime index. We briefly present the formal SDE methodology below on how to obtain the weights that lead to the highest measured organized crime (please refer to Scaillet and Topaloglou 2010 and Pinar et al. 2013 for a more detailed discussion of the SDE methodology). We do not discuss how to obtain weights that lead to the lowest measured index to preserve space, but this could be obtained by reversing the order of the cumulative distribution functions under consideration.

We consider a $m \times N$ matrix of organized crime $C$ taking values in $\mathbb{R}^{m}$, where the observations consist of a realization of normalized crime levels in $m$ indicators of crime with $N$ observations (i.e., organized crime levels in different provinces over a given period). We denote by $F(y)$, the continuous cumulative distribution function (cdf) of $C=\left(C_{1}, C_{2}, \ldots, C_{m}\right)^{\prime}$ at point $c=\left(c_{1}, c_{2}, \ldots, c_{m}\right)^{\prime}$. Using an equallyweighted vector of weights, w (i.e., $\frac{1}{m} \mathrm{~s}$ ), one can obtain an equally-weighted organized crime index (OCI). Let us consider an alternative weighting vector of $\boldsymbol{w}_{a} \in \mathbb{L}$ where $\mathbb{L}:=\left(\boldsymbol{w}_{a} \in \mathbb{R}_{+}^{m}: \mathbf{e}^{\prime} \boldsymbol{w}_{a}=1\right)$ with e being a vector of ones suggesting that all crime indicators have non-negative weights that sum up to one. Let us denote by $G(s, w$; $F)$ and $G\left(s, \boldsymbol{w}_{a} ; F\right)$ as cdfs of the composite crime indices of $\boldsymbol{w}^{\prime} \boldsymbol{C}$ and $\boldsymbol{w}_{a}^{\prime} \boldsymbol{C}$ at point s given by $G(s, \boldsymbol{w} ; F)=\int_{\mathbb{R}^{m}} \square\left\{\boldsymbol{w}^{\prime} \boldsymbol{u} \leq s\right\} d F(\boldsymbol{u})$ and $G\left(s, \boldsymbol{w}_{a} ; F\right)=\int_{\mathbb{R}^{m}} \square\left\{\boldsymbol{w}_{a}^{\prime} \boldsymbol{u} \leq s\right\} d F(\boldsymbol{u})$, respectively, where s represents a crime index score, $\square$ is an indicator function, and $\boldsymbol{u}$ is an increasing monotonic function of such that $\boldsymbol{u}^{\prime}(s)>0$ (see Scaillet and Topaloglou 2010 for further details).

The general hypotheses for testing the first-order of SDE of the composite organized crime index obtained with an equally-weighted vector can be written compactly as:

$$
\begin{aligned}
& H_{0}: G(s, \boldsymbol{w} ; F) \leq G\left(s, \boldsymbol{w}_{a} ; F\right) \text { for all } s \in \mathbb{R} \text { and for all } \boldsymbol{w}_{a} \in \mathbb{L}, \\
& H_{1}: G(s, \boldsymbol{w} ; F) \leq G\left(s, \boldsymbol{w}_{a} ; F\right) \text { for some } s \in \mathbb{R} \text { and for some } \boldsymbol{w}_{a} \in \mathbb{L}
\end{aligned}
$$

Under the null hypothesis $\left(H_{0}\right)$, the distribution of the equally-weighted OCI is not bigger in magnitude than any distribution of OCI with alternative weights. Therefore, $G(s, w ; F)$ (i.e., the cumulative distribution of equally-weighted OCI) is smaller than $G\left(s, \boldsymbol{w}_{a} ; F\right)$ (i.e., the cumulative distribution of OCI with alternative weights) for all organized crime index scores of $s$. If the null hypothesis is not rejected, this suggests 
that the equally-weighted OCI has a distribution of composite organized indices that produces a higher proportion of provinces that have a score that is above any given OCI scores of $s$. To summarize, under the null, the equally-weighted OCI carries "more crime" than any other index with alternative weights.

On the other hand, under the alternative hypothesis $\left(H_{1}\right)$, for some index scores, $\mathrm{s}$, some provinces' OCI scores with alternative weights are higher in magnitude than the ones obtained with the equally-weighted OCI. Therefore, $G(s, \boldsymbol{w} ; F)$ is greater than $G\left(s, \boldsymbol{w}_{a} ; F\right)$ for some index scores and the equally-weighted OCI is stochastically dominated by OCI with alternative weights at some scores. This suggests that the proportion of provinces with OCI scores less than $s$ is smaller for the OCI with alternative weights than for the equally-weighted one. Therefore, if the null hypothesis is rejected, this suggests that OCI obtained with alternative weights (i.e., $\boldsymbol{w}_{a}$ ) would have a higher proportion of provinces with OCI scores that are higher than $s$ when compared to the equally-weighted OCI.

The empirical counterparts of the both distributions can be obtained as follows:

$$
\begin{gathered}
G(s, \boldsymbol{w} ; \hat{F})=\frac{1}{N} \sum_{n=1}^{N} \llbracket\left\{\boldsymbol{w}^{\prime} \boldsymbol{C} \leq s\right\}, \\
G\left(s, \boldsymbol{w}_{a} ; \hat{F}\right)=\frac{1}{N} \sum_{n=1}^{N} \llbracket\left\{\boldsymbol{w}_{a}^{\prime} \boldsymbol{C} \leq s\right\} .
\end{gathered}
$$

Given the above-specified empirical counterparts, we consider the weighted Kolmogorov-Smirnov type test statistic to test for the null hypothesis:

$$
\hat{S}:=\frac{\sqrt{N}}{N} \sup _{s, \boldsymbol{w}_{a}}\left[G(s, \boldsymbol{w} ; \hat{F})-G\left(s, \boldsymbol{w}_{a} ; \hat{F}\right)\right]
$$

and a test based on the decision rule:

$$
\text { Reject } H_{0} \text { if } \hat{S}>z
$$

where $\mathrm{z}$ is some critical value (for the derivation of the test, see Scaillet and Topaloglu 2010 and Pinar et al. 2013). Since the distribution of the test statistic depends on the underlying distribution, we rely on a subsampling bootstrap method adopted by Linton et al. (2014). Finally, we obtain the test statistic for the first-order SDE test by using a mixed-integer programming formulation (see Sect. 4 of Pinar et al. 2013 for the derivation of mathematical formulation).

\section{Empirical analysis}

\subsection{Highest and lowest measured organized crime}

Using the SDE methodology, we find that the equally-weighted organized crime index does not result in the highest or lowest measured organized crime index and 
that there are alternative combinations of different types of crime variables that would stochastically dominate the equally-weighted OCI in the first-order sense. Panels A to $\mathrm{G}$ of Table 4 provide the weight allocations across the crime indicators that lead to the highest and lowest organized crime index (HOCI and LOCI hereafter) outcomes across Italian provinces when different sets of indicators are used to construct OCI (see Sect. 2.2 for the detailed choice of indicators for construction of OCIs).

When we examine the "criminal conspiracy" dimension (Panel A of Table 4), we find that the presence of a criminal association across Italian provinces is relatively higher compared to that of a mafia-type association. Drug-related (usury) crimes are relatively more (less) present across the Italian provinces [i.e., an indicator that gets relatively more weight in the HOCI (LOCI) scenario in Panel B of Table 4)] when indicators that are linked with the "provision of illicit goods and services" dimension are used to construct an index. When we use the indicators listed under the "use of violence, threat or intimidation" dimension, we find that threats and mafia murders are the indicators that are more and less present across Italian provinces (see panel C of Table 4), while fraud activity and councils dissolved due to mafia infiltration were more and less present across Italian provinces when the indicators in the "infiltration of legitimate business or government" are used (see Panel D of Table 4). When mafia-related variables (i.e., mafia murder, mafia-type association, councils dissolved due to mafia infiltration and assets confiscated) are considered with other sets of variables (see Panels F and G of Table 4), we find that extortion and drug-related criminal activities are more present across Italian provinces and none of the mafia-related variables contributes to the HOCI. In contrast, councils dissolved due to mafia infiltration is the least present crime across Italian provinces when mafia-type variables and/or other variables are considered to construct an index (see Panels E-G of Table 4). If some indicators have little presence or variation across the Italian peninsula such as mafia-related crimes, inclusion of these indicators with other indicators, when an equally-weighted index or principal component analysis is used to obtain indices, would make their contribution to the composite index fairly limited. However, with the use of SDE methodology, these indicators are important as they contribute significantly to obtain the lowest organised crime index (lower bound of the feasible range of composite indices). Hence, these indicators play a major role in the construction of the feasible range of composite organised crime, whereas they would have been otherwise underrepresented with the equally-weighted index or with the index obtained with the principal component analysis.

Even though the average OCI is highly and positively correlated with the HOCI and LOCI for all seven categories, the correlation coefficients between HOCI and LOCI are not significantly correlated with one another, or the correlation among these two extreme scenarios are relatively weaker (see "Appendix" Table 12), which suggests that there are major rank reversals among Italian provinces based on the weight choices in the construction of organized crime indices (see "Appendix" 


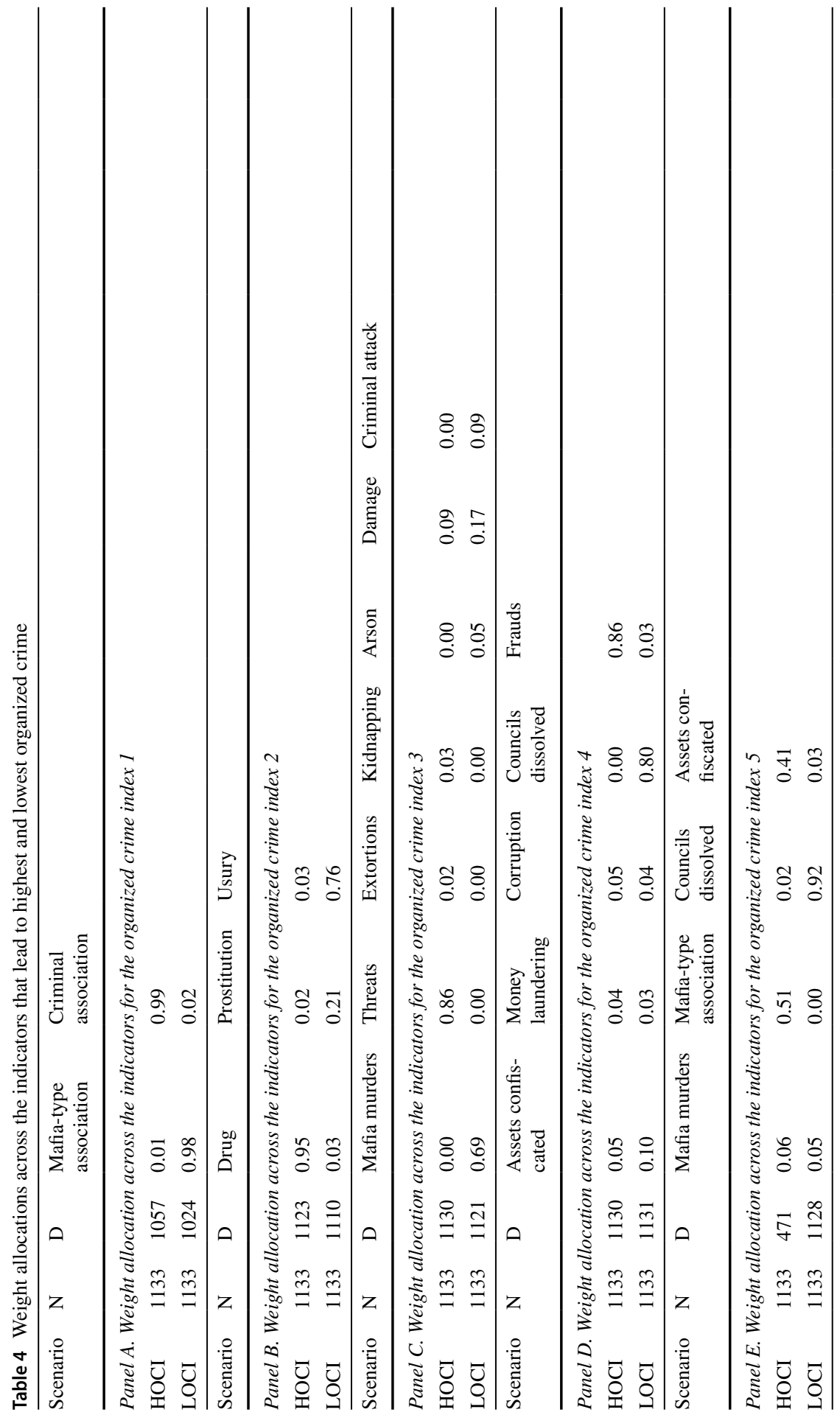




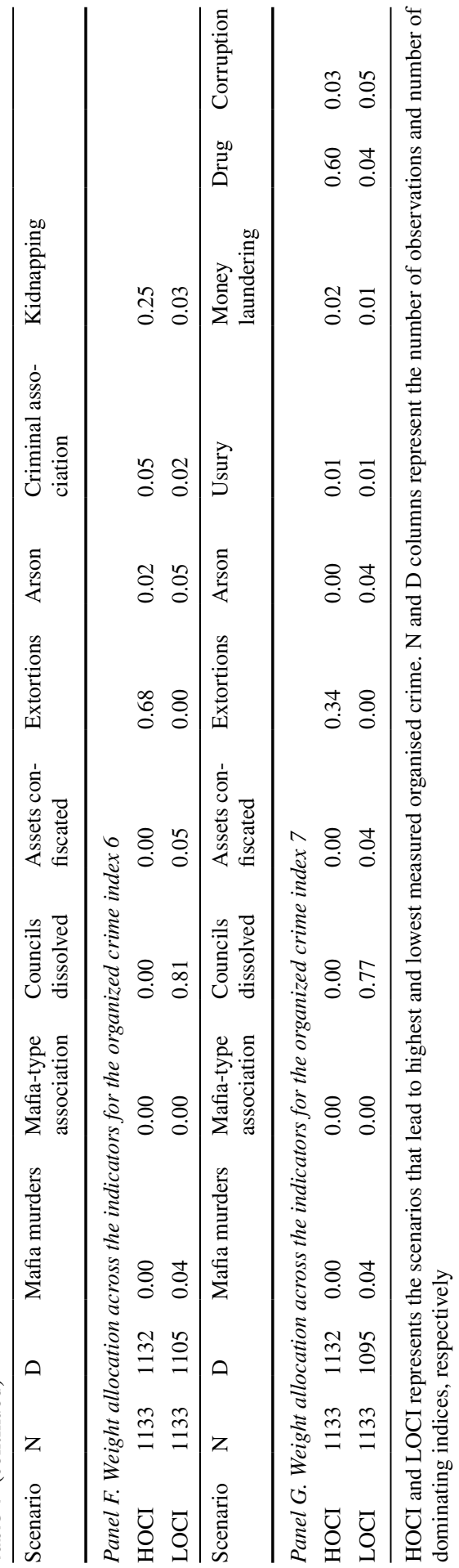


Tables 13, 14, 15, 16, 17, 18, 19 for the average OCI, HOCI and LOCI scores and respective rankings in 7 categories in 2014). ${ }^{3}$

Rank is important for policymakers especially because they want to identify in which province intervention is most needed to mitigate or eliminate the negative effects of organized crime on socio-economic development. The above-ranking analysis suggests that the choice of indicators and the weight associated with them leads to major reversals in the rankings of provinces producing very different levels of intensity of organized crime. Figure 1 provides the distribution of organized crime across Italian provinces in 2014 when HOCI and LOCI are used. In these maps, darker colors correspond to a wider presence of criminal activity. As expected, the presence of the criminal organizations is mostly concentrated in some Southern provinces (Naples and Caserta in Campania, Reggio Calabria, Vibo Valentia, Crotone and Catanzaro in Calabria, Palermo, Trapani, Agrigento and Caltanissetta in Sicily, and Bari and Lecce in Apulia). However, the geographical distribution of these indicators varies based on the choice of indicators and weights attached to them. Figure 1 also reports the difference between HOCI and LOCI outcomes highlighting the extent of the variation in organized crime outcomes when a different set of weights are attached to crime indicators.

When the dimension of criminal conspiracy is considered, we observe that criminal association is highly diffused within the central-southern provinces while Mafia-type association, captured by the LOCI scenario, is clustered mostly on the southern side (see Fig. 1a). Although lower and higher scenario differ in terms of intensity, we can observe that in both cases the activities related with the provision of illicit goods and services are widely diffused among the centralnorthern provinces (see Fig. 1b) while the violence, threat or intimidation type of crime were more present in the south of Italy (see Fig. 1c). This finding is consistent with the fact that mafia's activities are mainly focused on control and exploitation of territory in the South of Italy, while infiltrations of legal economy and control of illegal markets prevail in the rest of the Peninsula. Figure 1d shows results in terms of the infiltration of legitimate business or government. The distribution of the HOCI is somewhat ambiguous, but the highest values of the LOCI are mostly clustered in the Southern regions where the mafia is historically rooted (e.g., Palermo, Trapani, Siracusa in Sicily and Reggio Calabria, Vibo Valentia e Catanzaro in Calabria). When we examine the distributions of the three remaining indices that are tailored to measure the presence of four mafiatype crimes alongside other indicators, we also observe major variation in index outcomes when a different set of indicators and weights are used (see panels E to

\footnotetext{
${ }^{3}$ Clearly, clustering indicators into different themes would affect the results obtained. For robustness, we carried out an additional analysis where we included the whole set of indicators (i.e., 17 indicators) in the analysis. In this analysis, we found that the fraud, threat, drug, extortion and damage related criminal activities contribute $46 \%, 38 \%, 9 \%, 4 \%$ and $3 \%$ to the HOCI, respectively. On the other hand, crime variables that measure the number of councils dissolved, mafia murders, assets confiscated, mafia-type association, and corruption contribute to the LOCI with the weights of $75 \%, 7 \%, 7 \%, 6 \%$ and $5 \%$, respectively. Appendix Tables 20 offers the average OCI, HOCI and LOCI scores and respective rankings when 17 indicators are used to obtain indices.
} 
(a) Criminal conspiracy index



Highest-case scenario



Lowest-case scenario

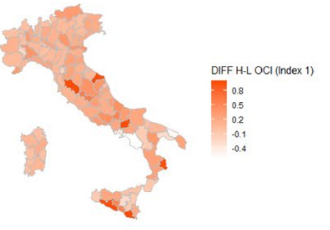

Difference HOCI1-LOCI1

(b) Provision of illicit goods and services index

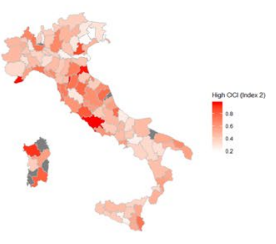

Highest-case scenario

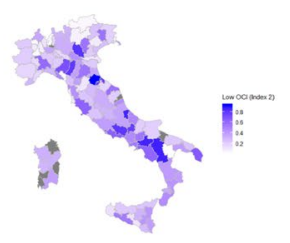

Lowest-case scenario

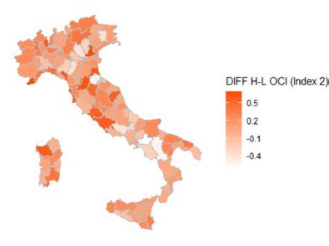

Difference HOCI2-LOCI2

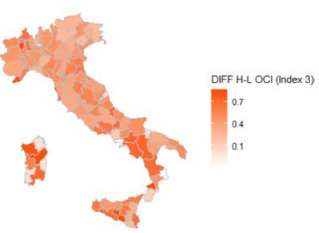

Difference HOCI3-LOCI3

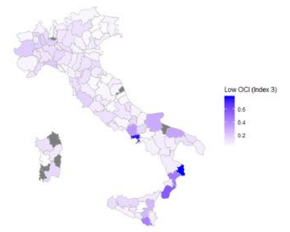

Lowest-case scenario

(c) Use of violence, threat or intimidation index

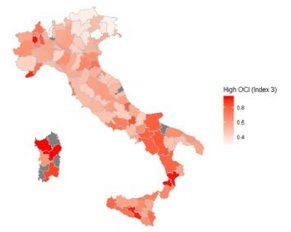

Highest-case scenario

(d) Infiltration of legitimate business or Government index



Highest-case scenario

e) Mafia-index 1

Mafia-index 1

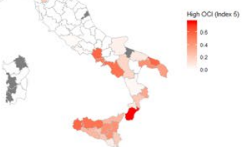

Highest-case scenario

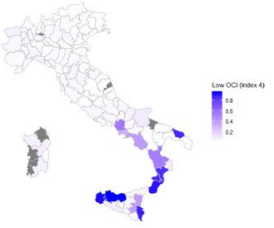

Lowest-case scenario



Difference HOCI4-LOCI4

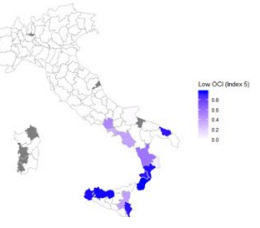

Lowest-case scenario

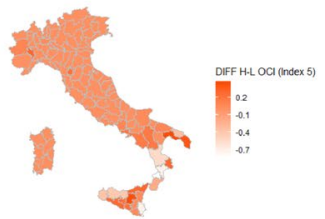

Difference HOCI5-LOCI5

Fig. 1 Distribution of organized crime index at provincial level in 2014 




(g) Mafia-index 3

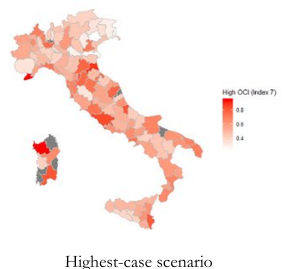

Highest-case scenario

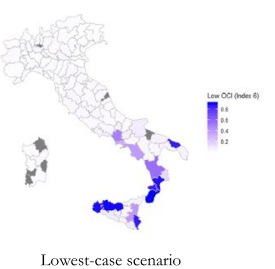

Lowest-case scenario



Lowest-case scenario
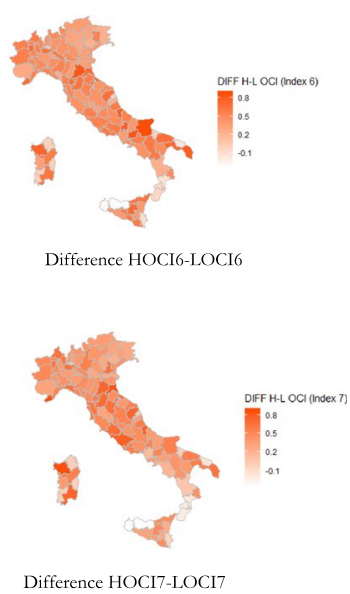

Fig. 1 (continued)

G of Fig. 1). Distribution of the crime index outcomes across the Italian peninsula with the LOCI scenario is fully consistent among the three cases depicting a clear spatial pattern that unsurprisingly identifies the presence of organized crime in the Southern regions. On the contrary, the distribution with the HOCI scenarios varies widely among the three cases since the indicators that make it up and their weights change. When four mafia-type crime variables are considered (panel E of Table 4), we observe that the criminal activity in the central and northern regions was rarely observed irrespective of the weights attached to the indicators. The index shows very limited variation between HOCI and LOCI when only four indicators are considered; however, when the other indicators are included in the four mafia-type crimes, the variation across HOCI and LOCI is extremely high. The inclusion of additional indicators to the index leads to a more homogeneous distribution across the Italian peninsula with the equally weighted index, suggesting that including additional indicators to these four mafia-type crimes blurs the region-specific crime activities. However, obtaining two extreme scenarios enables one to highlight such cases.

To conclude the discussion, Fig. 1 includes additional maps for each case that provide the difference between the two extreme scenarios. In particular, darker colors correspond to the case in which the score of HOCI is greater than the LOCI while transparent colors present the opposite scenario. In general, we observe that the average variation across these two extreme scenarios is relatively higher when the indicators in "Use of violence, threat or intimidation" and "Infiltration of legitimate business or Government" dimensions are allocated different sets of weights, where the average difference per province between the two extreme scenarios is 0.45 and 0.55 , respectively. Similarly, when mafia-type crimes are used with other indicators (mafia index-2 and mafia index-3), allocating alternative weights to indicators leads to major index outcome differences. Finally, the variation between HOCI and LOCI scenarios is 
relatively lower when the indicators in "criminal conspiracy" and "provision of illicit goods and services" dimensions are combined with alternative weights and when four mafia-type crimes are used. In sum, we can argue that the literature using the mafiatype crimes with other indicators lead to the underestimation of criminal groups in the southern regions and indicators that only use the mafia-type crimes (e.g., Calderoni 2014) underrepresent the criminal groups in North-Central Italy.

\subsection{Robustness analysis}

In the baseline analysis (Sect. 4.1), we excluded some of the important variables (i.e., bombing/incendiary attacks, bank/postal robbery, smuggling, track robbery) that are measuring important crimes committed by criminal organisations. The reason why these indicators are excluded from the analysis is that they lack data for some years and inclusion of these indicators with the others would limit the number of observations in our analysis as the SDE methodology requires a balanced data set. However, to test the robustness of our baseline analysis, we examine the role of the four additional indicators for the HOCI and LOCI when each variable (i.e., bombing/incendiary attacks, bank/postal robbery, smuggling, track robbery) is included to the indicator list one at a time with the existing other indicators.

The "bombing or incendiary attacks" variable is not available after 2003, so we repeated the exercise by using variables that has information between 1991 and 2003, and this variable does not contribute neither to the HOCI nor LOCI. Henceforth, its exclusion from analysis does not affect the feasible range of organised crime index. ${ }^{4}$ With respect to other indicators, there is data for the "bank/postal robbery" and "smuggling" variables for the period between 2008 and 2014, and for the "track robbery" between 2010 and 2014. Henceforth, we carried out two sets of analysis: (1) analysis with 19 variables when the "bank/postal robbery" and "smuggling" variables are part of the analysis with the remaining 17 variables, which covers the period between 2008 and 2014 and (2) analysis with 20 variables when the "bank/postal robbery", "smuggling" and "track robbery" variables are part of the analysis with the remaining 17 variables, which covers the period between 2010 and 2014.

For the analysis for the period between 2008 and 2014 with the 19 variables, we find that the fraud, threat, drug and damage related crimes contribute to the HOCI with weights of $52 \%, 32 \%, 12 \%$ and $4 \%$, respectively. Whereas, crimes variables that measure the number of councils dissolved, mafia murders, mafia type association, assets confiscated and smuggling contribute to the LOCI with weights of $72 \%, 9 \%$, $7 \%, 6 \%$ and $6 \%$, respectively. On the other hand, when we use 20 variables in our analysis when the period between 2010 and 2014 are considered, we find that fraud, threat, drug and damage related crimes contribute to the HOCI with weights of $48 \%, 38 \%$, $10 \%$, and $4 \%$, respectively, and crimes variables that measure the number of councils dissolved, mafia murders, mafia type association, assets confiscated and smuggling contribute to the LOCI with weights of $75 \%, 7 \%, 6 \%, 7 \%$ and $5 \%$, respectively.

Overall, our findings suggest that our results are mostly robust to the inclusion of the four type of crime variables (i.e., bombing/incendiary attacks, bank/postal robbery, smuggling, track robbery) to the analysis as their inclusion does not affect the calculation of the HOCI and LOCI with one exception. The only exception is that the smuggling

\footnotetext{
${ }^{4}$ The results are available from authors upon request.
} 
variable contributes to the calculation of the LOCI suggesting that the inclusion of smuggling to obtain the least organised crime index is needed but the contribution of smuggling to the LOCI is relatively lower compared to the contribution of other indicators.

\subsection{Sensitivity of organized crime indices and its implications for socio-economic development}

HOCI and LOCI provide a feasible range of organised crime variable outcome for Italian provinces. Therefore, irrespective of the weight (importance) given to different crime indicators, one can assess the range of organised crime outcome of a given province. Furthermore, another important aspect for policymakers would be to assess whether a correlation between organised crime and socioeconomic factors based on the two extreme cases of measuring organised crime (lowest and highest organised crime distribution across Italian provinces irrespective of the importance given to the indicators) would exist. Hence, in this subsection, we further examine whether different ways of measuring organized crime have any particular effects on the socio-economic variables. To examine the relationship between organized crime and socio-economic variables, we use a different set of socio-economic factors. Table 5 provides the list of socio-economic indicators used and their source and descriptive statistics, and the latest year availability of the variables. We use measures of institutional quality indices for Italian provinces (corruption, government, role of law, regulatory and institutional quality index) Nifo and Vecchione (2014), where a higher index score represents a better institutional setting. We also use the percentage of the population with secondary and tertiary education levels, the natural logarithm of GDP per capita, the natural logarithm of value-added per worker as a proxy for productivity differences, which are obtained from the European Regional Database (ERD). Finally, we also use different indexes of social mobility from Acciari et al. (2017) where higher scores represent more chances of social mobility.

Table 6 shows that the correlation coefficients between socio-economic indicators and $\mathrm{OC}$ indexes are generally very strong and with the expected sign. In line with the previous literature, the correlation coefficients of organized crime and institutional quality index, social mobility, productivity and income are negative suggesting that organized crime is a limit to local development. The education level of the province is also negatively associated with organized crime index but does not show a strong correlation. Looking at the results in more detail, we can see that index 2 that measures the provision of illicit goods and services does not show a strong and significant correlation with socio-economic statistics irrespective of the weights given to each indicator in this dimension. We also find that when HOCI-4 and HOCI-7 are used to measure organized crime across Italian provinces, the correlation coefficients between organized crime indices and most of the socio-economic indicators are not significant. Overall, even though most of the organized crime indices (i.e., 16 out of 21 indices presented in Table 6) have a negative correlation with socio-economic indicators irrespective of the indicator choice and weights attached to them, there are also few exceptions (5 out of 21 indices) where the correlation between organized crime index and socioeconomic factors is not significant. In conclusion, irrespective of the importance (weight) given to the crime indicators 


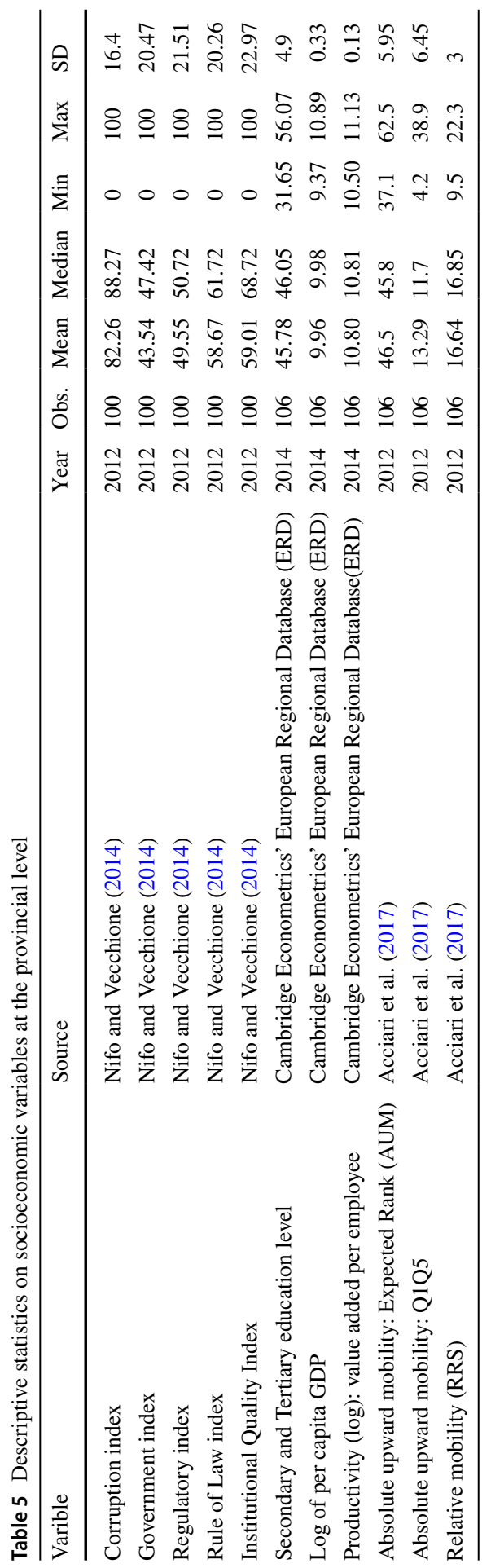


that leads to lowest and highest organised crime distribution across Italian provinces, the analysis in this section showed that organised crime is significantly and negatively correlated with the socioeconomic factors irrespective of the importance (weight) given to individual indicators. Hence, policymakers could be reassured that irrespective of the importance (weight) attached to indicators to construct an overall organised crime index, organised crime results in negative the socioeconomic outcomes.

\section{Conclusion and policy discussions}

There is an extensive literature that studies the effects of organized crime on institutional quality, economic growth, and performance of firms, among many other socio-economic conditions. However, the definition and the use of organized crime differ as there is no consensus on which variables should be considered as part of the organized crime index and their relative importance in the construction of such an index. In this paper, we aim at identifying a broad set of organized crime indices and provide a sensitivity analysis of organized crime across the Italian provinces based on the choice of indicators and the weights given to these indicators. Following the definition of organized crime provided UNODC, indices (1)-(4) are built to cluster the main categories of illegal behaviors connected to different categories of criminal activity. Indices 5-7, instead, are tailored to measure the presence and sensitivity of the major mafia-type criminality, which is historically rooted in Italy, based on the set of indicators that are closely associated with such criminal activities. We then provide the distribution of organized crime index outcomes across the Italian provinces based on the different sets of indicators and weight choices, which also enables us to examine the level of sensitivity of organized crime to these choices. We find that both the rankings and the intensity of organized crime vary dramatically when different indicators are used to construct organized crime indices and when these indicators are given different weights. Hence, our findings highlight the sensitivity of organized crime indices on normative judgments, and as such that one should be cautious while making decisions based on these indices.

With the use of SDE methodology, we obtain two extreme case scenarios that provide weighting vectors that lead to the highest and lowest measured organized crime indices (HOCI and LOCI, respectively). From one side, the HOCI scenario allowed us to group a set of crime types that were observed more frequently across provinces and time that would require nation-wide policies. On the other side, the LOCI scenario takes into consideration indicators that occur less frequently and are extremely concentrated in a limited number of provinces allowing a good measure of the presence of criminal organizations that are historically rooted in southern Italy. Our results suggest the need for diversified strategies among Italian provinces to fight criminal organizations in a more effective way. In particular, in North-Central Italian provinces, there is the need to identify specific law enforcement policies to fight drug trafficking, prostitution and money laundering. However, the strategy in southern provinces must be aimed at the traditional mafia's activities. Indicators that were more frequently observed across Italian provinces (e.g., drug-related crime, extortions, kidnapping) require more nation-wide policies. 


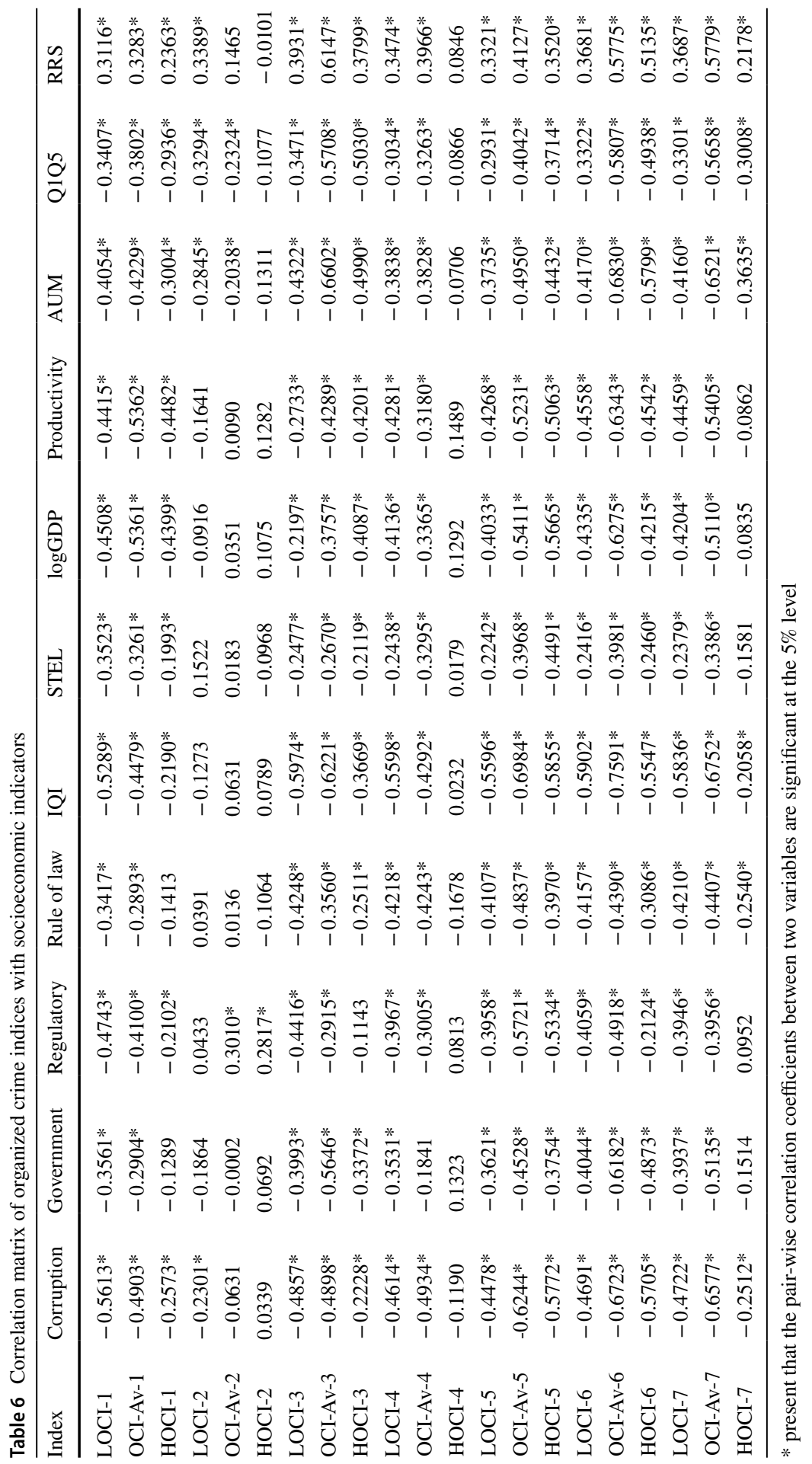


Our results could provide guidance for policymaking. First, policymakers should be aware that the distribution of organised crime spatially and over-time would depend on the choice of the indicators used to obtain an organised crime index and the importance (weight) attached to each one of them. To overcome such uncertainty, this paper offers a feasible range of organised crime index in provinces irrespective of the weight attached to them. Policymakers may also choose to allocate their limited resources to fight against organised crime where provinces in which there is a higher presence of organised crime are prioritised. As such, the ranking of provinces in terms of their organised crime activity is also important. Our paper offers rankings of provinces based on the presence of organised crime for two extreme scenario and policymakers could identify high ranking provinces irrespective of measurement issues. In other words, provinces that are ranked in high positions would be prioritised as high crime provinces irrespective of subjective indicator and weight choices.

Finally, we examine the correlation between organised crime indices and several socio-economic indicators. We find that in provinces where organized crime levels are higher tend to do worse socio-economically with most of the organized crime indices constructed in this paper irrespective of the indicator choice and importance attached to these indicators. However, there were also few exceptions where organized crime levels were not significantly correlated with the socio-economic factors based on the indicator choice (i.e., all indices constructed with the use of drug, prostitution, and usury related crimes). This highlights the fact that empirical literature examining the relationship between organized crime and some socio-economic concepts should be cautious about the robustness of their findings and should require additional checks with the use of different organized crime indicators and alternative aggregation methods.

Acknowledgements The authors would like to thank the editor and two anonymous reviewers for their suggestions and comments. The authors would like to thank Michele Battisti, Mario Lavezzi and participants of the 60th Annual Conference (RSA) of the Italian Economic Association (SIE).

Funding Giovanni Bernardo acknowledges the support of the National Operational Programme of Italian Ministry of Education, University and Research under the project AIM (Attraction and International Mobility - AIM1813213 - 1).

Open Access This article is licensed under a Creative Commons Attribution 4.0 International License, which permits use, sharing, adaptation, distribution and reproduction in any medium or format, as long as you give appropriate credit to the original author(s) and the source, provide a link to the Creative Commons licence, and indicate if changes were made. The images or other third party material in this article are included in the article's Creative Commons licence, unless indicated otherwise in a credit line to the material. If material is not included in the article's Creative Commons licence and your intended use is not permitted by statutory regulation or exceeds the permitted use, you will need to obtain permission directly from the copyright holder. To view a copy of this licence, visit http://creativecommons.org/licen ses/by/4.0/.

\section{Appendix}

See Tables 7, 8, 9, 10, 11, 12, 13, 14, 15, 16, 17, 18, 19 and 20. 


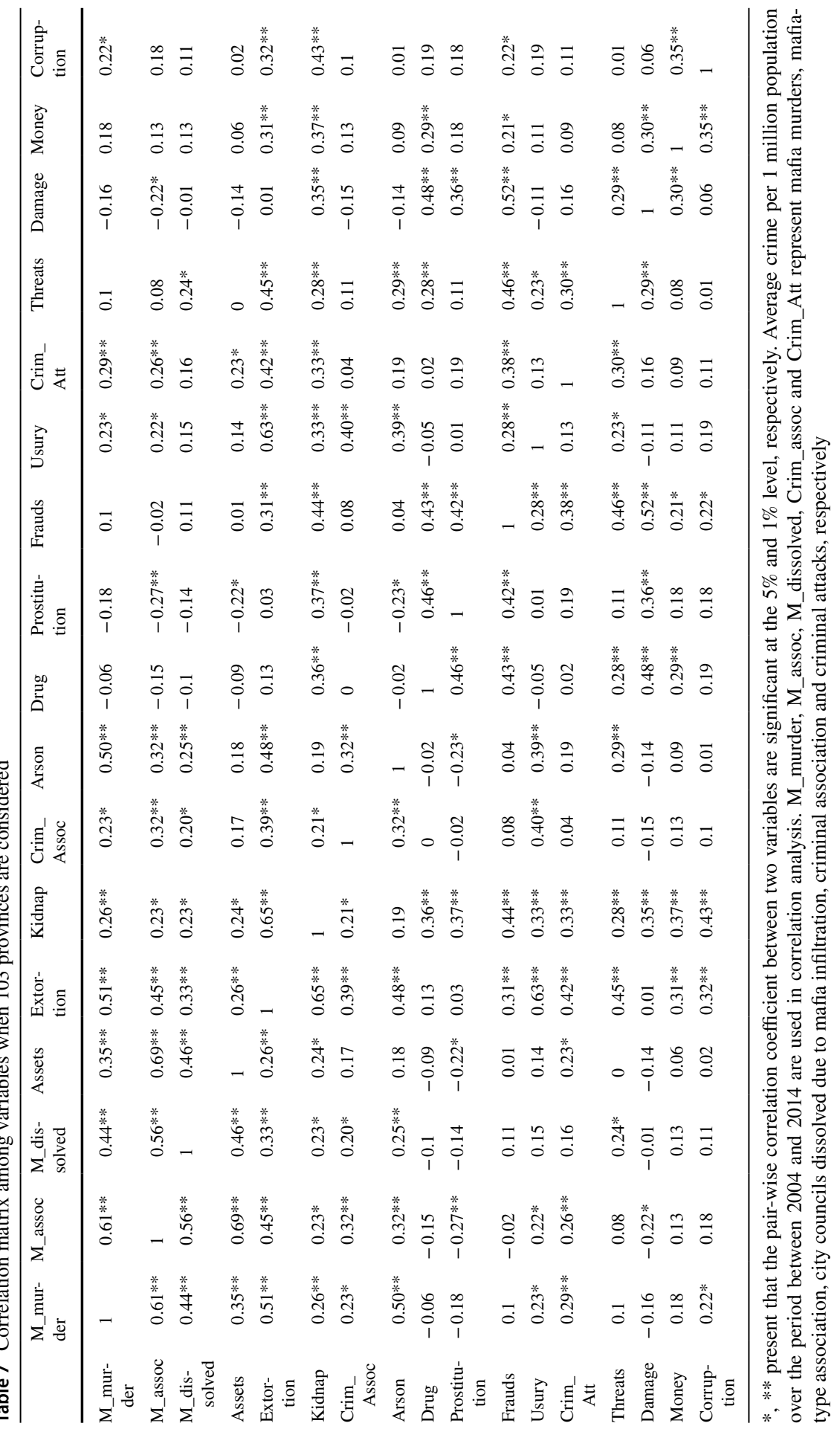


Table 8 Categorization of the Italian provinces into different groups

\begin{tabular}{|c|c|c|c|c|c|}
\hline Province & Location & Province & Location & Province & Location \\
\hline Agrigento & Southern & Gorizia & Northern & Ragusa & Southern \\
\hline Alessandria & Northern & Grosseto & Central & Ravenna & Northern \\
\hline Ancona & Central & Imperia & Northern & Reggio di Calabria & Southern \\
\hline Aosta & Northern & Isernia & Southern & Reggio Emilia & Northern \\
\hline Arezzo & Central & La Spezia & Northern & Rieti & Central \\
\hline Ascoli Piceno & Central & L'Aquila & Southern & Rimini & Northern \\
\hline Asti & Northern & Latina & Central & Roma & Central \\
\hline Avellino & Southern & Lecce & Southern & Rovigo & Northern \\
\hline Bari & Southern & Lecco & Northern & Salerno & Southern \\
\hline Belluno & Northern & Livorno & Central & Sassari & Southern \\
\hline Benevento & Southern & Lodi & Northern & Savona & Northern \\
\hline Bergamo & Northern & Lucca & Central & Siena & Central \\
\hline Biella & Northern & Macerata & Central & Siracusa & Southern \\
\hline Bologna & Northern & Mantova & Northern & Sondrio & Northern \\
\hline Bolzano & Northern & Massa and Carrara & Central & Taranto & Southern \\
\hline Brescia & Northern & Matera & Southern & Teramo & Southern \\
\hline Brindisi & Southern & Messina & Southern & Terni & Central \\
\hline Cagliari & Southern & Milano & Northern & Torino & Northern \\
\hline Caltanissetta & Southern & Modena & Northern & Trapani & Southern \\
\hline Campobasso & Southern & Napoli & Southern & Trento & Northern \\
\hline Caserta & Southern & Novara & Northern & Treviso & Northern \\
\hline Catania & Southern & Nuoro & Southern & Trieste & Northern \\
\hline Catanzaro & Southern & Oristano & Southern & Udine & Northern \\
\hline Chieti & Southern & Padova & Northern & Varese & Northern \\
\hline Como & Northern & Palermo & Southern & Venezia & Northern \\
\hline Cosenza & Southern & Parma & Northern & Verbano-Cusio-Ossola & Northern \\
\hline Cremona & Northern & Pavia & Northern & Vercelli & Northern \\
\hline Crotone & Southern & Perugia & Central & Verona & Northern \\
\hline Cuneo & Northern & Pesaro and Urbino & Central & Vibo Valentia & Southern \\
\hline Enna & Southern & Pescara & Southern & Vicenza & Northern \\
\hline Ferrara & Northern & Piacenza & Northern & Viterbo & Central \\
\hline Firenze & Central & Pisa & Central & & \\
\hline Foggia & Southern & Pistoia & Central & & \\
\hline Forlì_Cesena & Northern & Pordenone & Northern & & \\
\hline Frosinone & Central & Potenza & Southern & & \\
\hline Genova & Northern & Prato & Central & & \\
\hline
\end{tabular}








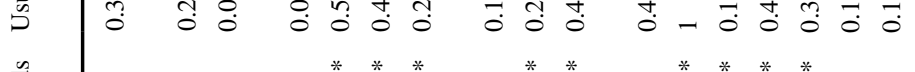

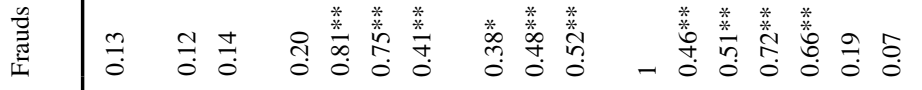

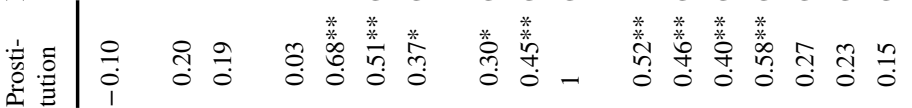

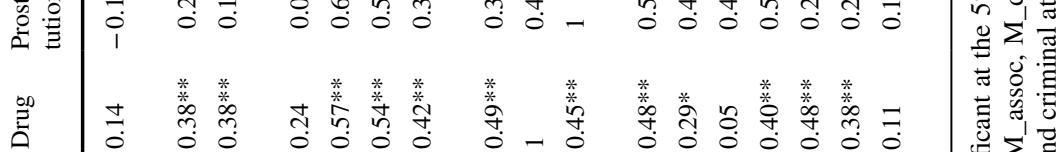

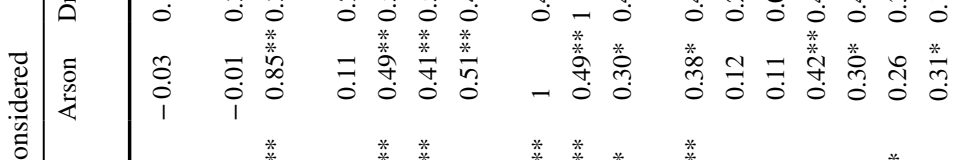

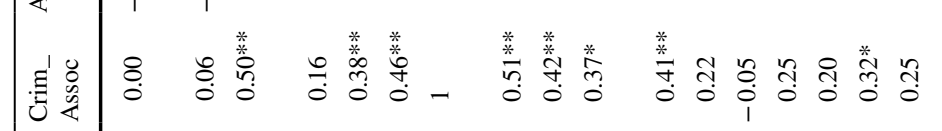
过

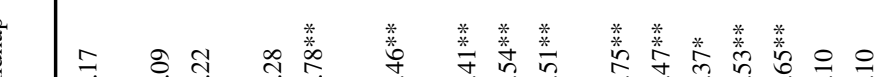



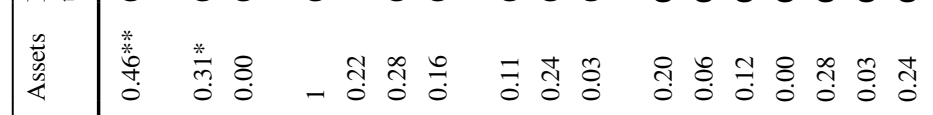

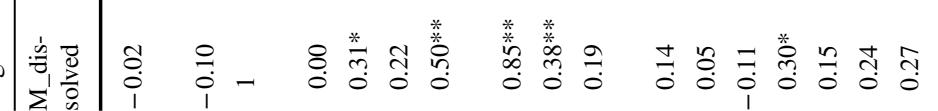

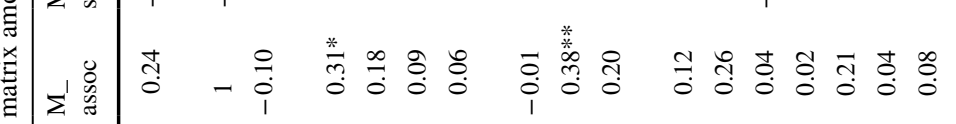


己 㝴 ज्ञ in :

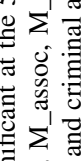
कू 言

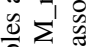




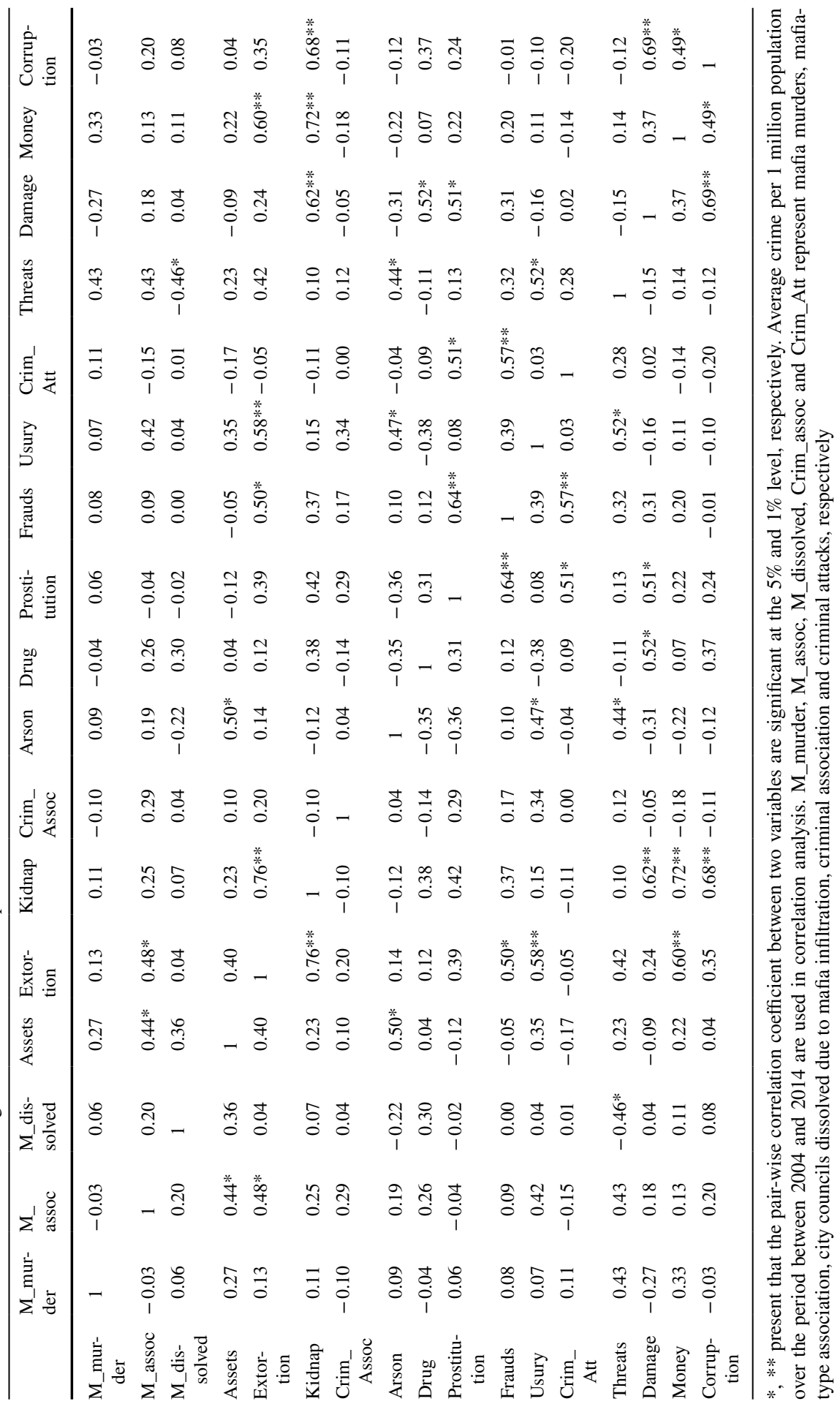






㐫

言离



部考

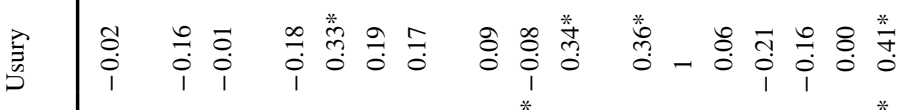

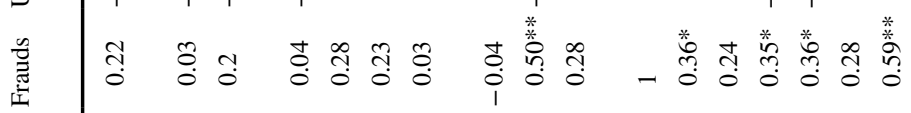



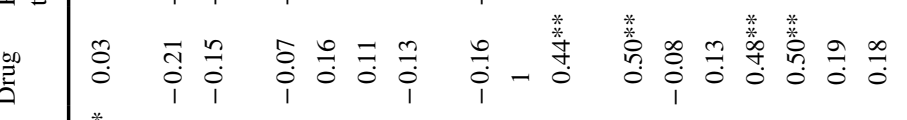

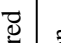

豙

自䓪

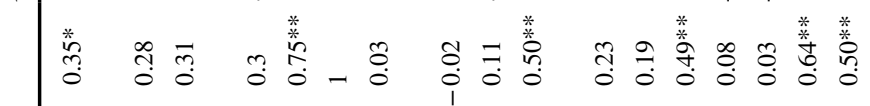

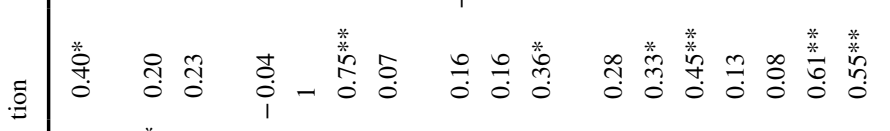



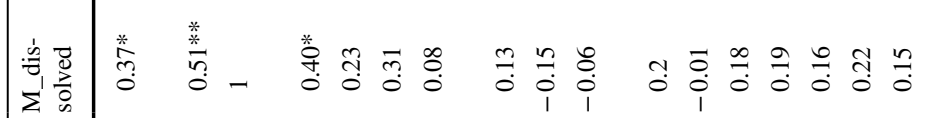

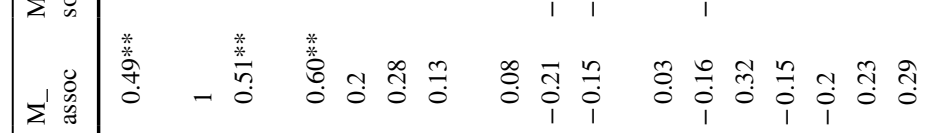

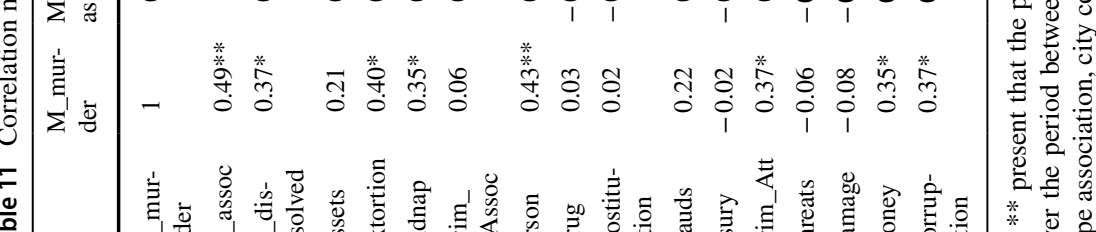

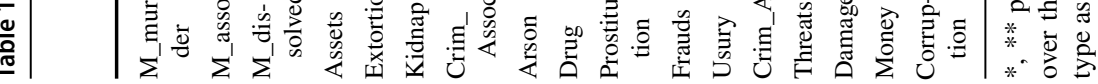




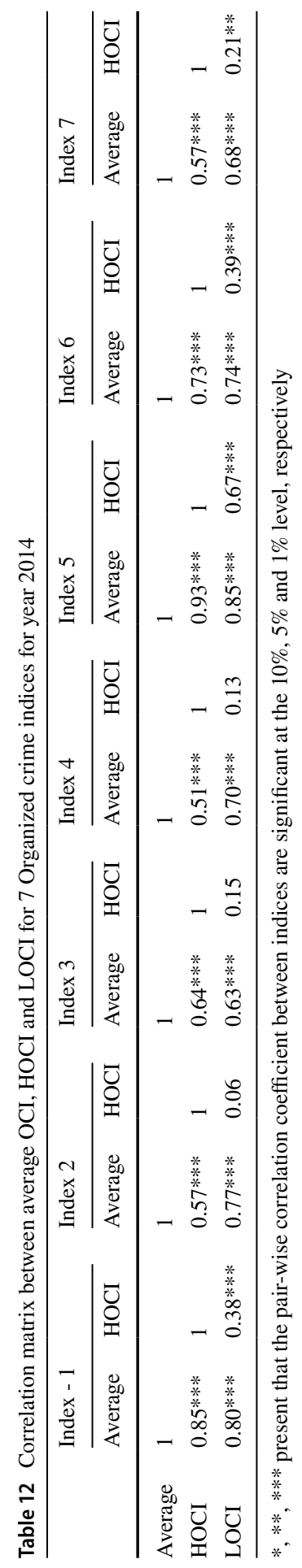


Table 13 Composite index scores and rankings in 2014 for the case 1

\begin{tabular}{|c|c|c|c|c|c|c|c|}
\hline Region & Province & OCI-Av & HOCI & LOCI & Rank-Av & Rank-HOCI & Rank-LOCI \\
\hline Abruzzo & Chieti & 21.81 & 43.18 & 0.87 & 27 & 17 & 31 \\
\hline Abruzzo & L'Aquila & 8.00 & 15.84 & 0.32 & 65 & 65 & 65 \\
\hline Abruzzo & Pescara & 15.22 & 30.14 & 0.61 & 42 & 36 & 44 \\
\hline Abruzzo & Teramo & 7.89 & 15.62 & 0.32 & 66 & 66 & 66 \\
\hline Basilicata & Matera & 18.30 & 36.23 & 0.73 & 33 & 27 & 37 \\
\hline Basilicata & Potenza & 25.78 & 19.64 & 31.80 & 24 & 56 & 14 \\
\hline Calabria & Catanzaro & 46.94 & 60.39 & 33.77 & 15 & 11 & 13 \\
\hline Calabria & Cosenza & 13.64 & 27.01 & 0.55 & 44 & 38 & 46 \\
\hline Calabria & Crotone & 49.33 & 97.68 & 1.97 & 12 & 7 & 26 \\
\hline Calabria & Reggio di Calabria & 96.02 & 92.13 & 99.84 & 1 & 9 & 1 \\
\hline Calabria & Vibo Valentia & 15.02 & 29.73 & 0.60 & 43 & 37 & 45 \\
\hline Campania & Avellino & 11.41 & 22.58 & 0.46 & 55 & 50 & 55 \\
\hline Campania & Benevento & 50.00 & 99.00 & 2.00 & 8 & 3 & 22 \\
\hline Campania & Caserta & 37.02 & 47.63 & 26.63 & 18 & 14 & 16 \\
\hline Campania & Napoli & 61.78 & 42.75 & 80.41 & 6 & 19 & 4 \\
\hline Campania & Salerno & 46.05 & 16.15 & 75.34 & 16 & 64 & 6 \\
\hline Emilia-Romagna & Bologna & 13.48 & 26.69 & 0.54 & 47 & 40 & 48 \\
\hline Emilia-Romagna & Ferrara & 6.91 & 13.68 & 0.28 & 70 & 70 & 70 \\
\hline Emilia-Romagna & Forlì Cesena & 6.19 & 12.25 & 0.25 & 71 & 71 & 71 \\
\hline Emilia-Romagna & Modena & 1.75 & 3.47 & 0.07 & 90 & 90 & 90 \\
\hline Emilia-Romagna & Parma & 2.77 & 5.48 & 0.11 & 86 & 86 & 86 \\
\hline Emilia-Romagna & Piacenza & 0.00 & 0.00 & 0.00 & 92 & 92 & 92 \\
\hline Emilia-Romagna & Ravenna & 12.51 & 24.76 & 0.50 & 49 & 43 & 50 \\
\hline Emilia-Romagna & Reggio Emilia & 4.59 & 9.09 & 0.18 & 75 & 75 & 75 \\
\hline Emilia-Romagna & Rimini & 3.67 & 7.27 & 0.15 & 79 & 79 & 79 \\
\hline $\begin{array}{l}\text { Friuli-Venezia } \\
\text { Giulia }\end{array}$ & Gorizia & 0.00 & 0.00 & 0.00 & 92 & 92 & 92 \\
\hline $\begin{array}{l}\text { Friuli-Venezia } \\
\text { Giulia }\end{array}$ & Pordenone & 11.70 & 23.16 & 0.47 & 52 & 46 & 52 \\
\hline $\begin{array}{l}\text { Friuli-Venezia } \\
\text { Giulia }\end{array}$ & Trieste & 0.00 & 0.00 & 0.00 & 92 & 92 & 92 \\
\hline $\begin{array}{l}\text { Friuli-Venezia } \\
\text { Giulia }\end{array}$ & Udine & 9.12 & 18.06 & 0.36 & 62 & 59 & 62 \\
\hline Lazio & Frosinone & 22.19 & 43.93 & 0.89 & 26 & 16 & 30 \\
\hline Lazio & Latina & 17.23 & 34.11 & 0.69 & 34 & 28 & 38 \\
\hline Lazio & Rieti & 15.37 & 30.43 & 0.61 & 41 & 35 & 43 \\
\hline Lazio & Roma & 12.47 & 21.95 & 3.18 & 50 & 52 & 21 \\
\hline Lazio & Viterbo & 7.62 & 15.08 & 0.30 & 69 & 69 & 69 \\
\hline Liguria & Genova & 11.31 & 22.39 & 0.45 & 56 & 51 & 56 \\
\hline Liguria & Imperia & 16.91 & 33.47 & 0.68 & 36 & 31 & 39 \\
\hline Liguria & La Spezia & 11.03 & 21.85 & 0.44 & 57 & 53 & 57 \\
\hline Liguria & Savona & 4.32 & 8.56 & 0.17 & 77 & 77 & 77 \\
\hline Lombardia & Bergamo & 8.86 & 17.55 & 0.35 & 64 & 61 & 64 \\
\hline
\end{tabular}


Table 13 (continued)

\begin{tabular}{|c|c|c|c|c|c|c|c|}
\hline Region & Province & OCI-Av & HOCI & LOCI & Rank-Av & Rank-HOCI & Rank-LOCI \\
\hline Lombardia & Brescia & 5.83 & 11.55 & 0.23 & 72 & 72 & 72 \\
\hline Lombardia & Como & 4.10 & 8.11 & 0.16 & 78 & 78 & 78 \\
\hline Lombardia & Cremona & 13.55 & 26.83 & 0.54 & 45 & 39 & 47 \\
\hline Lombardia & Lecco & 0.00 & 0.00 & 0.00 & 92 & 92 & 92 \\
\hline Lombardia & Lodi & 0.00 & 0.00 & 0.00 & 92 & 92 & 92 \\
\hline Lombardia & Mantova & 2.96 & 5.85 & 0.12 & 84 & 84 & 84 \\
\hline Lombardia & Milano & 15.39 & 23.02 & 7.92 & 40 & 47 & 20 \\
\hline Lombardia & Pavia & 2.24 & 4.43 & 0.09 & 88 & 88 & 88 \\
\hline Lombardia & Sondrio & 0.00 & 0.00 & 0.00 & 92 & 92 & 92 \\
\hline Lombardia & Varese & 9.67 & 19.15 & 0.39 & 61 & 58 & 61 \\
\hline Marche & Ancona & 50.00 & 99.00 & 2.00 & 8 & 3 & 22 \\
\hline Marche & Ascoli Piceno & 11.59 & 22.94 & 0.46 & 53 & 48 & 53 \\
\hline Marche & Macerata & 19.09 & 37.80 & 0.76 & 31 & 24 & 35 \\
\hline Marche & Pesaro Urbino & 3.37 & 6.67 & 0.13 & 82 & 82 & 82 \\
\hline Molise & Campobasso & 16.18 & 32.03 & 0.65 & 39 & 34 & 42 \\
\hline Molise & Isernia & 28.12 & 55.68 & 1.12 & 23 & 12 & 29 \\
\hline Piemonte & Alessandria & 19.79 & 39.18 & 0.79 & 30 & 23 & 34 \\
\hline Piemonte & Asti & 44.21 & 33.67 & 54.53 & 17 & 30 & 8 \\
\hline Piemonte & Biella & 0.00 & 0.00 & 0.00 & 92 & 92 & 92 \\
\hline Piemonte & Cuneo & 2.07 & 4.10 & 0.08 & 89 & 89 & 89 \\
\hline Piemonte & Novara & 16.50 & 32.68 & 0.66 & 38 & 33 & 41 \\
\hline Piemonte & Torino & 17.01 & 23.36 & 10.78 & 35 & 45 & 18 \\
\hline Piemonte & $\begin{array}{l}\text { Verbano Cusio } \\
\text { Ossola }\end{array}$ & 0.00 & 0.00 & 0.00 & 92 & 92 & 92 \\
\hline Piemonte & Vercelli & 0.00 & 0.00 & 0.00 & 92 & 92 & 92 \\
\hline Puglia & Bari & 13.54 & 17.42 & 9.74 & 46 & 62 & 19 \\
\hline Puglia & Brindisi & 63.48 & 37.19 & 89.23 & 5 & 25 & 2 \\
\hline Puglia & Foggia & 11.59 & 22.94 & 0.46 & 54 & 49 & 54 \\
\hline Puglia & Lecce & 87.44 & 99.75 & 75.39 & 2 & 1 & 5 \\
\hline Puglia & Taranto & 67.98 & 54.32 & 81.37 & 4 & 13 & 3 \\
\hline Sardegna & Cagliari & 4.37 & 8.66 & 0.17 & 76 & 76 & 76 \\
\hline Sardegna & Nuoro & 7.72 & 15.28 & 0.31 & 68 & 68 & 68 \\
\hline Sardegna & Oristano & 0.00 & 0.00 & 0.00 & 92 & 92 & 92 \\
\hline Sardegna & Sassari & 3.66 & 7.25 & 0.15 & 80 & 80 & 80 \\
\hline Sicilia & Agrigento & 49.20 & 97.42 & 1.97 & 13 & 8 & 27 \\
\hline Sicilia & Caltanissetta & 72.00 & 99.44 & 45.13 & 3 & 2 & 10 \\
\hline Sicilia & Catania & 49.08 & 44.08 & 53.98 & 14 & 15 & 9 \\
\hline Sicilia & Enna & 56.39 & 42.96 & 69.56 & 7 & 18 & 7 \\
\hline Sicilia & Messina & 35.68 & 34.09 & 37.23 & 19 & 29 & 12 \\
\hline Sicilia & Palermo & 30.64 & 42.08 & 19.42 & 22 & 20 & 17 \\
\hline Sicilia & Ragusa & 50.00 & 99.00 & 2.00 & 8 & 3 & 22 \\
\hline Sicilia & Siracusa & 9.09 & 18.00 & 0.36 & 63 & 60 & 63 \\
\hline
\end{tabular}


Table 13 (continued)

\begin{tabular}{|c|c|c|c|c|c|c|c|}
\hline Region & Province & OCI-Av & HOCI & LOCI & Rank-Av & Rank-HOCI & Rank-LOCI \\
\hline Sicilia & Trapani & 22.30 & 16.99 & 27.50 & 25 & 63 & 15 \\
\hline Toscana & Arezzo & 10.62 & 21.02 & 0.42 & 58 & 54 & 58 \\
\hline Toscana & Firenze & 13.40 & 26.53 & 0.54 & 48 & 41 & 49 \\
\hline Toscana & Grosseto & 5.45 & 10.79 & 0.22 & 74 & 74 & 74 \\
\hline Toscana & Livorno & 3.60 & 7.13 & 0.14 & 81 & 81 & 81 \\
\hline Toscana & Lucca & 3.11 & 6.16 & 0.12 & 83 & 83 & 83 \\
\hline Toscana & Massa Carrara & 12.25 & 24.25 & 0.49 & 51 & 44 & 51 \\
\hline Toscana & Pisa & 2.92 & 5.78 & 0.12 & 85 & 85 & 85 \\
\hline Toscana & Pistoia & 33.33 & 25.39 & 41.11 & 20 & 42 & 11 \\
\hline Toscana & Prato & 9.69 & 19.18 & 0.39 & 60 & 57 & 60 \\
\hline Toscana & Siena & 50.00 & 99.00 & 2.00 & 8 & 3 & 22 \\
\hline $\begin{array}{l}\text { Trentino-Alto } \\
\text { Adige }\end{array}$ & Bolzano & 16.65 & 32.97 & 0.67 & 37 & 32 & 40 \\
\hline $\begin{array}{l}\text { Trentino-Alto } \\
\text { Adige }\end{array}$ & Trento & 2.29 & 4.53 & 0.09 & 87 & 87 & 87 \\
\hline Umbria & Perugia & 20.29 & 40.17 & 0.81 & 28 & 21 & 32 \\
\hline Umbria & Terni & 31.79 & 62.95 & 1.27 & 21 & 10 & 28 \\
\hline Valle d'Aosta & Aosta & 0.00 & 0.00 & 0.00 & 92 & 92 & 92 \\
\hline Veneto & Belluno & 0.00 & 0.00 & 0.00 & 92 & 92 & 92 \\
\hline Veneto & Padova & 7.86 & 15.57 & 0.31 & 67 & 67 & 67 \\
\hline Veneto & Rovigo & 20.11 & 39.81 & 0.80 & 29 & 22 & 33 \\
\hline Veneto & Treviso & 1.38 & 2.74 & 0.06 & 91 & 91 & 91 \\
\hline Veneto & Venezia & 10.01 & 19.82 & 0.40 & 59 & 55 & 59 \\
\hline Veneto & Verona & 18.63 & 36.89 & 0.75 & 32 & 26 & 36 \\
\hline Veneto & Vicenza & 5.64 & 11.17 & 0.23 & 73 & 73 & 73 \\
\hline
\end{tabular}

OCI-Av, HOCI, and LOCI represent index outcomes with the equally-weighted, highest and lowest OCI scores, respectively. Rank-Av, Rank-HOCI, and Rank-LOCI represent rankings with the equallyweighted, highest and lowest OCI scores, respectively 
Table 14 Composite index scores and rankings in 2014 for the case 2

\begin{tabular}{|c|c|c|c|c|c|c|c|}
\hline Region & Province & OCI-Av & HOCI & LOCI & Rank-Av & Rank-HOCI & Rank-LOCI \\
\hline Abruzzo & Chieti & 32.38 & 26.37 & 47.69 & 68 & 95 & 24 \\
\hline Abruzzo & L'Aquila & 40.01 & 47.61 & 37.01 & 50 & 49 & 42 \\
\hline Abruzzo & Pescara & 80.31 & 76.02 & 85.70 & 1 & 10 & 4 \\
\hline Abruzzo & Teramo & 42.94 & 56.91 & 36.80 & 45 & 33 & 43 \\
\hline Basilicata & Matera & 10.82 & 30.83 & 0.97 & 103 & 89 & 103 \\
\hline Basilicata & Potenza & 59.50 & 33.99 & 86.79 & 8 & 84 & 2 \\
\hline Calabria & Catanzaro & 42.84 & 56.20 & 42.59 & 46 & 34 & 30 \\
\hline Calabria & Cosenza & 35.82 & 44.55 & 40.65 & 57 & 58 & 33 \\
\hline Calabria & Crotone & 48.83 & 52.30 & 39.31 & 24 & 40 & 37 \\
\hline Calabria & Reggio di Calabria & 43.30 & 50.04 & 46.25 & 42 & 43 & 26 \\
\hline Calabria & Vibo Valentia & 34.33 & 35.50 & 34.45 & 61 & 83 & 47 \\
\hline Campania & Avellino & 55.67 & 24.62 & 86.15 & 14 & 97 & 3 \\
\hline Campania & Benevento & 45.76 & 40.12 & 54.92 & 35 & 69 & 20 \\
\hline Campania & Caserta & 44.44 & 45.49 & 47.02 & 39 & 57 & 25 \\
\hline Campania & Napoli & 48.16 & 58.59 & 53.83 & 28 & 29 & 21 \\
\hline Campania & Salerno & 45.26 & 35.70 & 62.05 & 38 & 82 & 14 \\
\hline Emilia-Romagna & Bologna & 58.72 & 68.89 & 55.82 & 10 & 19 & 19 \\
\hline Emilia-Romagna & Ferrara & 33.09 & 42.48 & 21.89 & 65 & 61 & 71 \\
\hline Emilia-Romagna & Forlì Cesena & 71.28 & 40.67 & 93.06 & 2 & 65 & 1 \\
\hline Emilia-Romagna & Modena & 38.49 & 46.42 & 38.20 & 54 & 52 & 40 \\
\hline Emilia-Romagna & Parma & 46.58 & 46.07 & 70.75 & 33 & 54 & 10 \\
\hline Emilia-Romagna & Piacenza & 25.38 & 31.31 & 21.15 & 83 & 87 & 75 \\
\hline Emilia-Romagna & Ravenna & 70.85 & 95.53 & 35.00 & 3 & 4 & 46 \\
\hline Emilia-Romagna & Reggio Emilia & 49.75 & 40.56 & 79.26 & 22 & 67 & 7 \\
\hline Emilia-Romagna & Rimini & 65.90 & 64.97 & 76.86 & 5 & 22 & 9 \\
\hline $\begin{array}{l}\text { Friuli-Venezia } \\
\text { Giulia }\end{array}$ & Gorizia & 19.76 & 21.36 & 8.55 & 96 & 100 & 96 \\
\hline $\begin{array}{l}\text { Friuli-Venezia } \\
\text { Giulia }\end{array}$ & Pordenone & 31.80 & 18.61 & 56.87 & 70 & 103 & 17 \\
\hline $\begin{array}{l}\text { Friuli-Venezia } \\
\text { Giulia }\end{array}$ & Trieste & 58.86 & 52.47 & 40.98 & 9 & 39 & 32 \\
\hline $\begin{array}{l}\text { Friuli-Venezia } \\
\text { Giulia }\end{array}$ & Udine & 20.85 & 30.73 & 19.15 & 94 & 90 & 81 \\
\hline Lazio & Frosinone & 57.58 & 40.01 & 79.86 & 12 & 70 & 6 \\
\hline Lazio & Latina & 58.52 & 61.82 & 64.31 & 11 & 27 & 12 \\
\hline Lazio & Rieti & 29.24 & 40.13 & 30.73 & 75 & 68 & 54 \\
\hline Lazio & Roma & 62.21 & 97.06 & 39.36 & 7 & 1 & 36 \\
\hline Lazio & Viterbo & 46.67 & 80.99 & 24.05 & 32 & 7 & 66 \\
\hline Liguria & Genova & 45.38 & 72.92 & 29.53 & 36 & 13 & 59 \\
\hline Liguria & Imperia & 52.91 & 96.44 & 29.76 & 17 & 3 & 58 \\
\hline Liguria & La Spezia & 50.09 & 58.54 & 49.16 & 21 & 31 & 23 \\
\hline Liguria & Savona & 25.99 & 55.57 & 17.03 & 82 & 36 & 84 \\
\hline Lombardia & Bergamo & 32.17 & 40.66 & 32.69 & 69 & 66 & 50 \\
\hline
\end{tabular}


Table 14 (continued)

\begin{tabular}{|c|c|c|c|c|c|c|c|}
\hline Region & Province & OCI-Av & HOCI & LOCI & Rank-Av & Rank-HOCI & Rank-LOCI \\
\hline Lombardia & Brescia & 43.73 & 65.53 & 32.85 & 40 & 21 & 49 \\
\hline Lombardia & Como & 17.98 & 37.51 & 4.28 & 100 & 79 & 99 \\
\hline Lombardia & Cremona & 23.37 & 38.49 & 16.25 & 91 & 77 & 86 \\
\hline Lombardia & Lecco & 19.55 & 25.83 & 16.79 & 98 & 96 & 85 \\
\hline Lombardia & Lodi & 23.79 & 37.70 & 21.73 & 90 & 78 & 72 \\
\hline Lombardia & Mantova & 29.04 & 24.23 & 44.31 & 76 & 98 & 29 \\
\hline Lombardia & Milano & 46.98 & 72.85 & 35.89 & 30 & 14 & 44 \\
\hline Lombardia & Pavia & 26.99 & 36.77 & 21.70 & 81 & 80 & 73 \\
\hline Lombardia & Sondrio & 33.35 & 39.22 & 31.08 & 64 & 71 & 53 \\
\hline Lombardia & Varese & 33.78 & 71.84 & 11.32 & 62 & 17 & 90 \\
\hline Marche & Ancona & 67.91 & 63.92 & 57.50 & 4 & 23 & 16 \\
\hline Marche & Ascoli Piceno & 40.40 & 49.99 & 46.01 & 49 & 44 & 27 \\
\hline Marche & Macerata & 39.39 & 75.45 & 20.48 & 53 & 11 & 78 \\
\hline Marche & Pesaro Urbino & 25.13 & 39.15 & 17.20 & 84 & 72 & 82 \\
\hline Molise & Campobasso & 19.73 & 33.12 & 20.10 & 97 & 86 & 79 \\
\hline Molise & Isernia & 48.92 & 47.42 & 77.40 & 23 & 50 & 8 \\
\hline Piemonte & Alessandria & 62.38 & 46.01 & 60.17 & 6 & 55 & 15 \\
\hline Piemonte & Asti & 34.46 & 30.95 & 16.12 & 60 & 88 & 87 \\
\hline Piemonte & Biella & 30.27 & 50.20 & 9.71 & 73 & 42 & 94 \\
\hline Piemonte & Cuneo & 28.56 & 33.67 & 17.13 & 77 & 85 & 83 \\
\hline Piemonte & Novara & 20.79 & 28.30 & 7.87 & 95 & 93 & 97 \\
\hline Piemonte & Torino & 31.23 & 47.24 & 20.50 & 71 & 51 & 77 \\
\hline Piemonte & $\begin{array}{l}\text { Verbano Cusio } \\
\text { Ossola }\end{array}$ & 45.28 & 65.94 & 35.82 & 37 & 20 & 45 \\
\hline Piemonte & Vercelli & 17.53 & 40.68 & 3.37 & 101 & 64 & 101 \\
\hline Puglia & Bari & 34.93 & 52.93 & 22.16 & 59 & 38 & 69 \\
\hline Puglia & Brindisi & 32.95 & 63.66 & 24.52 & 66 & 25 & 65 \\
\hline Puglia & Foggia & 29.25 & 46.12 & 19.76 & 74 & 53 & 80 \\
\hline Puglia & Lecce & 53.92 & 55.59 & 66.78 & 15 & 35 & 11 \\
\hline Puglia & Taranto & 43.12 & 48.29 & 39.68 & 43 & 46 & 35 \\
\hline Sardegna & Cagliari & 48.09 & 79.06 & 38.03 & 29 & 8 & 41 \\
\hline Sardegna & Nuoro & 35.35 & 57.37 & 31.40 & 58 & 32 & 52 \\
\hline Sardegna & Oristano & 28.34 & 38.59 & 29.99 & 78 & 76 & 57 \\
\hline Sardegna & Sassari & 48.19 & 91.26 & 32.07 & 27 & 5 & 51 \\
\hline Sicilia & Agrigento & 40.65 & 39.00 & 53.64 & 48 & 74 & 22 \\
\hline Sicilia & Caltanissetta & 25.08 & 23.60 & 11.52 & 85 & 99 & 89 \\
\hline Sicilia & Catania & 46.82 & 53.04 & 42.38 & 31 & 37 & 31 \\
\hline Sicilia & Enna & 31.08 & 39.04 & 30.66 & 72 & 73 & 55 \\
\hline Sicilia & Messina & 24.87 & 36.43 & 23.49 & 86 & 81 & 68 \\
\hline Sicilia & Palermo & 32.70 & 45.79 & 22.00 & 67 & 56 & 70 \\
\hline Sicilia & Ragusa & 42.23 & 52.19 & 26.90 & 47 & 41 & 61 \\
\hline Sicilia & Siracusa & 46.24 & 72.54 & 38.98 & 34 & 15 & 38 \\
\hline
\end{tabular}


Table 14 (continued)

\begin{tabular}{|c|c|c|c|c|c|c|c|}
\hline Region & Province & OCI-Av & HOCI & LOCI & Rank-Av & Rank-HOCI & Rank-LOCI \\
\hline Sicilia & Trapani & 21.72 & 42.32 & 12.97 & 93 & 62 & 88 \\
\hline Toscana & Arezzo & 52.17 & 76.62 & 27.74 & 19 & 9 & 60 \\
\hline Toscana & Firenze & 33.77 & 73.08 & 10.65 & 63 & 12 & 92 \\
\hline Toscana & Grosseto & 51.14 & 61.13 & 62.99 & 20 & 28 & 13 \\
\hline Toscana & Livorno & 37.08 & 71.87 & 9.88 & 56 & 16 & 93 \\
\hline Toscana & Lucca & 27.45 & 43.28 & 25.21 & 79 & 60 & 63 \\
\hline Toscana & Massa Carrara & 22.40 & 63.84 & 2.02 & 92 & 24 & 102 \\
\hline Toscana & Pisa & 55.76 & 70.56 & 44.62 & 13 & 18 & 28 \\
\hline Toscana & Pistoia & 39.96 & 44.07 & 38.71 & 51 & 59 & 39 \\
\hline Toscana & Prato & 53.02 & 96.63 & 40.21 & 16 & 2 & 34 \\
\hline Toscana & Siena & 27.45 & 28.48 & 23.74 & 80 & 92 & 67 \\
\hline $\begin{array}{l}\text { Trentino-Alto } \\
\text { Adige }\end{array}$ & Bolzano & 18.02 & 38.60 & 4.09 & 99 & 75 & 100 \\
\hline $\begin{array}{l}\text { Trentino-Alto } \\
\text { Adige }\end{array}$ & Trento & 24.56 & 48.52 & 6.36 & 87 & 45 & 98 \\
\hline Umbria & Perugia & 48.70 & 63.21 & 33.23 & 25 & 26 & 48 \\
\hline Umbria & Terni & 43.46 & 58.57 & 30.16 & 41 & 30 & 56 \\
\hline Valle d'Aosta & Aosta & 48.21 & 47.89 & 21.66 & 26 & 48 & 74 \\
\hline Veneto & Belluno & 24.13 & 27.99 & 25.12 & 88 & 94 & 64 \\
\hline Veneto & Padova & 43.05 & 86.55 & 20.97 & 44 & 6 & 76 \\
\hline Veneto & Rovigo & 23.87 & 20.86 & 11.28 & 89 & 101 & 91 \\
\hline Veneto & Treviso & 15.05 & 20.31 & 9.28 & 102 & 102 & 95 \\
\hline Veneto & Venezia & 38.18 & 48.26 & 26.18 & 55 & 47 & 62 \\
\hline Veneto & Verona & 52.66 & 42.03 & 80.85 & 18 & 63 & 5 \\
\hline Veneto & Vicenza & 39.88 & 28.67 & 56.27 & 52 & 91 & 18 \\
\hline
\end{tabular}

OCI-Av, HOCI, and LOCI represent index outcomes with the equally-weighted, highest and lowest OCI scores, respectively. Rank-Av, Rank-HOCI, and Rank-LOCI represent rankings with the equallyweighted, highest and lowest OCI scores, respectively 
Table 15 Composite index scores and rankings in 2014 for the case 3

\begin{tabular}{|c|c|c|c|c|c|c|c|}
\hline Region & Province & OCI-Av & $\mathrm{HOCI}$ & LOCI & Rank-Av & Rank-HOCI & Rank-LOCI \\
\hline Abruzzo & Chieti & 30.59 & 55.97 & 7.69 & 76 & 61 & 74 \\
\hline Abruzzo & L'Aquila & 32.62 & 53.04 & 7.41 & 66 & 69 & 79 \\
\hline Abruzzo & Pescara & 46.24 & 78.96 & 12.42 & 19 & 14 & 34 \\
\hline Abruzzo & Teramo & 32.56 & 60.34 & 6.28 & 67 & 43 & 87 \\
\hline Basilicata & Matera & 32.48 & 48.38 & 8.90 & 69 & 86 & 65 \\
\hline Basilicata & Potenza & 44.26 & 81.10 & 9.03 & 27 & 10 & 63 \\
\hline Calabria & Catanzaro & 59.38 & 93.13 & 45.95 & 4 & 5 & 4 \\
\hline Calabria & Cosenza & 48.36 & 77.96 & 9.60 & 13 & 16 & 55 \\
\hline Calabria & Crotone & 53.80 & 59.01 & 78.05 & 9 & 50 & 1 \\
\hline Calabria & Reggio di Calabria & 62.45 & 67.41 & 56.42 & 1 & 28 & 3 \\
\hline Calabria & Vibo Valentia & 44.46 & 93.69 & 9.63 & 26 & 3 & 53 \\
\hline Campania & Avellino & 35.86 & 79.14 & 5.26 & 52 & 13 & 96 \\
\hline Campania & Benevento & 57.26 & 65.80 & 14.95 & 5 & 33 & 19 \\
\hline Campania & Caserta & 53.94 & 50.19 & 36.18 & 8 & 78 & 6 \\
\hline Campania & Napoli & 54.91 & 57.25 & 75.74 & 7 & 54 & 2 \\
\hline Campania & Salerno & 46.33 & 78.77 & 7.76 & 17 & 15 & 71 \\
\hline Emilia-Romagna & Bologna & 44.22 & 67.54 & 11.80 & 28 & 27 & 36 \\
\hline Emilia-Romagna & Ferrara & 27.04 & 65.79 & 7.64 & 84 & 34 & 76 \\
\hline Emilia-Romagna & Forlì Cesena & 37.00 & 54.60 & 9.63 & 49 & 65 & 54 \\
\hline Emilia-Romagna & Modena & 25.11 & 45.67 & 10.06 & 91 & 89 & 50 \\
\hline Emilia-Romagna & Parma & 36.60 & 64.67 & 10.82 & 50 & 37 & 42 \\
\hline Emilia-Romagna & Piacenza & 37.06 & 41.73 & 14.87 & 48 & 96 & 20 \\
\hline Emilia-Romagna & Ravenna & 49.64 & 74.38 & 13.91 & 11 & 20 & 22 \\
\hline Emilia-Romagna & Reggio Emilia & 30.90 & 56.51 & 8.84 & 74 & 59 & 67 \\
\hline Emilia-Romagna & Rimini & 43.90 & 66.02 & 10.48 & 29 & 31 & 46 \\
\hline $\begin{array}{l}\text { Friuli-Venezia } \\
\text { Giulia }\end{array}$ & Gorizia & 16.73 & 50.49 & 5.56 & 102 & 77 & 94 \\
\hline $\begin{array}{l}\text { Friuli-Venezia } \\
\text { Giulia }\end{array}$ & Pordenone & 23.34 & 35.46 & 3.54 & 93 & 99 & 103 \\
\hline $\begin{array}{l}\text { Friuli-Venezia } \\
\text { Giulia }\end{array}$ & Trieste & 35.70 & 61.84 & 10.40 & 53 & 41 & 47 \\
\hline $\begin{array}{l}\text { Friuli-Venezia } \\
\text { Giulia }\end{array}$ & Udine & 19.18 & 31.70 & 7.12 & 99 & 102 & 80 \\
\hline Lazio & Frosinone & 37.34 & 70.60 & 6.80 & 46 & 25 & 83 \\
\hline Lazio & Latina & 44.85 & 73.04 & 9.75 & 25 & 21 & 52 \\
\hline Lazio & Rieti & 29.92 & 60.30 & 5.88 & 77 & 45 & 90 \\
\hline Lazio & Roma & 38.60 & 48.52 & 12.74 & 42 & 85 & 30 \\
\hline Lazio & Viterbo & 38.57 & 53.13 & 9.57 & 43 & 68 & 56 \\
\hline Liguria & Genova & 40.08 & 49.67 & 20.04 & 41 & 79 & 10 \\
\hline Liguria & Imperia & 45.90 & 90.70 & 11.18 & 20 & 7 & 40 \\
\hline Liguria & La Spezia & 30.73 & 45.00 & 10.75 & 75 & 90 & 43 \\
\hline Liguria & Savona & 41.66 & 72.10 & 13.40 & 36 & 23 & 25 \\
\hline Lombardia & Bergamo & 34.24 & 56.76 & 10.86 & 59 & 58 & 41 \\
\hline
\end{tabular}


Table 15 (continued)

\begin{tabular}{|c|c|c|c|c|c|c|c|}
\hline Region & Province & OCI-Av & HOCI & LOCI & Rank-Av & Rank-HOCI & Rank-LOCI \\
\hline Lombardia & Brescia & 33.32 & 59.30 & 11.27 & 63 & 48 & 39 \\
\hline Lombardia & Como & 25.55 & 34.85 & 5.74 & 90 & 100 & 92 \\
\hline Lombardia & Cremona & 40.62 & 61.93 & 13.12 & 40 & 40 & 27 \\
\hline Lombardia & Lecco & 26.03 & 48.58 & 8.91 & 89 & 84 & 64 \\
\hline Lombardia & Lodi & 32.54 & 51.09 & 10.72 & 68 & 73 & 44 \\
\hline Lombardia & Mantova & 34.08 & 43.57 & 7.66 & 61 & 94 & 75 \\
\hline Lombardia & Milano & 45.35 & 60.01 & 17.69 & 22 & 46 & 13 \\
\hline Lombardia & Pavia & 32.70 & 58.69 & 13.58 & 65 & 52 & 24 \\
\hline Lombardia & Sondrio & 31.19 & 50.69 & 7.94 & 71 & 75 & 69 \\
\hline Lombardia & Varese & 37.55 & 52.90 & 13.35 & 45 & 71 & 26 \\
\hline Marche & Ancona & 30.96 & 48.80 & 9.08 & 73 & 83 & 61 \\
\hline Marche & Ascoli Piceno & 21.49 & 49.31 & 5.62 & 97 & 81 & 93 \\
\hline Marche & Macerata & 33.72 & 52.98 & 6.63 & 62 & 70 & 84 \\
\hline Marche & Pesaro Urbino & 26.47 & 46.52 & 5.19 & 86 & 88 & 97 \\
\hline Molise & Campobasso & 26.04 & 43.95 & 6.86 & 88 & 93 & 82 \\
\hline Molise & Isernia & 59.99 & 82.69 & 14.51 & 3 & 9 & 21 \\
\hline Piemonte & Alessandria & 34.80 & 56.91 & 11.31 & 57 & 55 & 38 \\
\hline Piemonte & Asti & 34.42 & 55.02 & 11.75 & 58 & 64 & 37 \\
\hline Piemonte & Biella & 40.90 & 93.54 & 9.83 & 39 & 4 & 51 \\
\hline Piemonte & Cuneo & 21.35 & 42.98 & 6.87 & 98 & 95 & 81 \\
\hline Piemonte & Novara & 50.73 & 80.40 & 18.37 & 10 & 11 & 12 \\
\hline Piemonte & Torino & 43.39 & 64.74 & 19.50 & 30 & 36 & 11 \\
\hline Piemonte & $\begin{array}{l}\text { Verbano Cusio } \\
\text { Ossola }\end{array}$ & 35.67 & 73.02 & 7.70 & 54 & 22 & 73 \\
\hline Piemonte & Vercelli & 43.25 & 67.04 & 16.93 & 31 & 30 & 15 \\
\hline Puglia & Bari & 55.31 & 65.96 & 32.50 & 6 & 32 & 7 \\
\hline Puglia & Brindisi & 46.99 & 62.27 & 12.38 & 16 & 39 & 35 \\
\hline Puglia & Foggia & 62.00 & 79.24 & 30.29 & 2 & 12 & 8 \\
\hline Puglia & Lecce & 41.51 & 58.94 & 8.86 & 38 & 51 & 66 \\
\hline Puglia & Taranto & 46.31 & 49.65 & 12.60 & 18 & 80 & 32 \\
\hline Sardegna & Cagliari & 44.95 & 85.78 & 15.25 & 24 & 8 & 17 \\
\hline Sardegna & Nuoro & 41.59 & 93.91 & 10.71 & 37 & 2 & 45 \\
\hline Sardegna & Oristano & 23.27 & 62.98 & 4.38 & 94 & 38 & 101 \\
\hline Sardegna & Sassari & 47.30 & 94.14 & 12.99 & 15 & 1 & 28 \\
\hline Sicilia & Agrigento & 35.07 & 75.28 & 7.61 & 55 & 19 & 77 \\
\hline Sicilia & Caltanissetta & 45.06 & 92.06 & 9.42 & 23 & 6 & 58 \\
\hline Sicilia & Catania & 42.50 & 56.88 & 26.08 & 34 & 56 & 9 \\
\hline Sicilia & Enna & 37.25 & 67.17 & 4.54 & 47 & 29 & 100 \\
\hline Sicilia & Messina & 42.17 & 70.41 & 10.12 & 35 & 26 & 49 \\
\hline Sicilia & Palermo & 34.12 & 59.09 & 15.23 & 60 & 49 & 18 \\
\hline Sicilia & Ragusa & 49.06 & 65.75 & 44.50 & 12 & 35 & 5 \\
\hline Sicilia & Siracusa & 42.98 & 75.37 & 9.16 & 32 & 18 & 59 \\
\hline
\end{tabular}


Table 15 (continued)

\begin{tabular}{|c|c|c|c|c|c|c|c|}
\hline Region & Province & OCI-Av & HOCI & LOCI & Rank-Av & Rank-HOCI & Rank-LOCI \\
\hline Sicilia & Trapani & 48.25 & 77.08 & 13.65 & 14 & 17 & 23 \\
\hline Toscana & Arezzo & 29.39 & 60.32 & 5.00 & 79 & 44 & 98 \\
\hline Toscana & Firenze & 36.43 & 49.05 & 12.45 & 51 & 82 & 33 \\
\hline Toscana & Grosseto & 45.36 & 51.30 & 17.62 & 21 & 72 & 14 \\
\hline Toscana & Livorno & 33.21 & 71.54 & 9.04 & 64 & 24 & 62 \\
\hline Toscana & Lucca & 31.16 & 55.93 & 7.75 & 72 & 62 & 72 \\
\hline Toscana & Massa Carrara & 21.94 & 59.45 & 6.22 & 96 & 47 & 88 \\
\hline Toscana & Pisa & 38.07 & 50.67 & 12.96 & 44 & 76 & 29 \\
\hline Toscana & Pistoia & 35.00 & 56.88 & 9.53 & 56 & 57 & 57 \\
\hline Toscana & Prato & 42.71 & 55.67 & 15.99 & 33 & 63 & 16 \\
\hline Toscana & Siena & 28.96 & 44.29 & 8.82 & 80 & 92 & 68 \\
\hline $\begin{array}{l}\text { Trentino-Alto } \\
\text { Adige }\end{array}$ & Bolzano & 22.84 & 33.56 & 6.30 & 95 & 101 & 86 \\
\hline $\begin{array}{l}\text { Trentino-Alto } \\
\text { Adige }\end{array}$ & Trento & 31.25 & 37.34 & 12.67 & 70 & 97 & 31 \\
\hline Umbria & Perugia & 28.00 & 61.32 & 6.40 & 83 & 42 & 85 \\
\hline Umbria & Terni & 24.02 & 46.63 & 9.08 & 92 & 87 & 60 \\
\hline Valle d'Aosta & Aosta & 29.47 & 58.16 & 6.09 & 78 & 53 & 89 \\
\hline Veneto & Belluno & 18.89 & 50.93 & 4.22 & 100 & 74 & 102 \\
\hline Veneto & Padova & 28.53 & 53.47 & 10.28 & 82 & 66 & 48 \\
\hline Veneto & Rovigo & 26.47 & 53.15 & 5.77 & 87 & 67 & 91 \\
\hline Veneto & Treviso & 14.71 & 27.55 & 4.55 & 103 & 103 & 99 \\
\hline Veneto & Venezia & 28.76 & 56.08 & 7.88 & 81 & 60 & 70 \\
\hline Veneto & Verona & 26.88 & 44.74 & 7.47 & 85 & 91 & 78 \\
\hline Veneto & Vicenza & 18.35 & 36.73 & 5.51 & 101 & 98 & 95 \\
\hline
\end{tabular}

OCI-Av, HOCI, and LOCI represent index outcomes with the equally-weighted, highest and lowest OCI scores, respectively. Rank-Av, Rank-HOCI, and Rank-LOCI represent rankings with the equallyweighted, highest and lowest OCI scores, respectively 
Table 16 Composite index scores and rankings in 2014 for the case 4

\begin{tabular}{|c|c|c|c|c|c|c|c|}
\hline Region & Province & OCI-Av & HOCI & LOCI & Rank-Av & Rank-HOCI & Rank-LOCI \\
\hline Abruzzo & Chieti & 29.54 & 66.30 & 5.09 & 42 & 51 & 40 \\
\hline Abruzzo & L'Aquila & 31.35 & 57.81 & 5.12 & 36 & 83 & 38 \\
\hline Abruzzo & Pescara & 28.38 & 78.64 & 4.46 & 46 & 23 & 53 \\
\hline Abruzzo & Teramo & 18.32 & 57.23 & 2.96 & 93 & 84 & 87 \\
\hline Basilicata & Matera & 19.09 & 53.11 & 2.86 & 89 & 89 & 91 \\
\hline Basilicata & Potenza & 18.52 & 60.31 & 2.78 & 92 & 73 & 93 \\
\hline Calabria & Catanzaro & 45.96 & 67.59 & 83.89 & 15 & 42 & 7 \\
\hline Calabria & Cosenza & 32.65 & 50.37 & 53.66 & 29 & 95 & 9 \\
\hline Calabria & Crotone & 29.77 & 44.92 & 9.48 & 41 & 101 & 14 \\
\hline Calabria & Reggio di Calabria & 65.97 & 88.37 & 90.87 & 2 & 10 & 3 \\
\hline Calabria & Vibo Valentia & 57.11 & 81.70 & 86.90 & 5 & 18 & 5 \\
\hline Campania & Avellino & 29.79 & 72.55 & 5.07 & 40 & 27 & 41 \\
\hline Campania & Benevento & 26.84 & 63.01 & 4.48 & 55 & 62 & 52 \\
\hline Campania & Caserta & 68.75 & 78.67 & 55.71 & 1 & 22 & 8 \\
\hline Campania & Napoli & 64.68 & 94.85 & 33.48 & 4 & 1 & 12 \\
\hline Campania & Salerno & 45.07 & 79.01 & 41.01 & 18 & 21 & 10 \\
\hline Emilia-Romagna & Bologna & 27.68 & 87.60 & 4.22 & 49 & 12 & 57 \\
\hline Emilia-Romagna & Ferrara & 24.64 & 64.91 & 3.70 & 65 & 58 & 72 \\
\hline Emilia-Romagna & Forlì Cesena & 19.83 & 66.89 & 2.97 & 84 & 46 & 86 \\
\hline Emilia-Romagna & Modena & 26.58 & 67.29 & 4.08 & 56 & 45 & 62 \\
\hline Emilia-Romagna & Parma & 24.38 & 71.31 & 3.95 & 67 & 31 & 65 \\
\hline Emilia-Romagna & Piacenza & 19.32 & 57.81 & 2.90 & 88 & 82 & 90 \\
\hline Emilia-Romagna & Ravenna & 26.21 & 69.61 & 4.10 & 59 & 36 & 61 \\
\hline Emilia-Romagna & Reggio Emilia & 18.89 & 62.15 & 2.83 & 91 & 66 & 92 \\
\hline Emilia-Romagna & Rimini & 30.94 & 88.58 & 5.03 & 37 & 9 & 42 \\
\hline $\begin{array}{l}\text { Friuli-Venezia } \\
\text { Giulia }\end{array}$ & Gorizia & 47.13 & 86.95 & 7.99 & 12 & 15 & 18 \\
\hline $\begin{array}{l}\text { Friuli-Venezia } \\
\text { Giulia }\end{array}$ & Pordenone & 17.95 & 63.31 & 2.69 & 96 & 61 & 96 \\
\hline $\begin{array}{l}\text { Friuli-Venezia } \\
\text { Giulia }\end{array}$ & Trieste & 40.00 & 90.00 & 6.00 & 20 & 6 & 26 \\
\hline $\begin{array}{l}\text { Friuli-Venezia } \\
\text { Giulia }\end{array}$ & Udine & 19.78 & 65.54 & 3.21 & 85 & 55 & 78 \\
\hline Lazio & Frosinone & 31.60 & 62.68 & 5.39 & 33 & 65 & 33 \\
\hline Lazio & Latina & 28.36 & 64.83 & 4.75 & 47 & 59 & 46 \\
\hline Lazio & Rieti & 22.60 & 46.08 & 3.80 & 73 & 99 & 71 \\
\hline Lazio & Roma & 35.38 & 71.37 & 5.85 & 24 & 29 & 28 \\
\hline Lazio & Viterbo & 19.59 & 61.61 & 2.94 & 87 & 68 & 89 \\
\hline Liguria & Genova & 40.72 & 87.04 & 6.18 & 19 & 14 & 25 \\
\hline Liguria & Imperia & 26.53 & 87.31 & 3.98 & 57 & 13 & 64 \\
\hline Liguria & La Spezia & 30.77 & 66.81 & 4.62 & 39 & 48 & 50 \\
\hline Liguria & Savona & 27.07 & 87.64 & 4.29 & 54 & 11 & 55 \\
\hline Lombardia & Bergamo & 22.65 & 67.37 & 3.57 & 72 & 44 & 73 \\
\hline
\end{tabular}


Table 16 (continued)

\begin{tabular}{|c|c|c|c|c|c|c|c|}
\hline Region & Province & OCI-Av & HOCI & LOCI & Rank-Av & Rank-HOCI & Rank-LOCI \\
\hline Lombardia & Brescia & 27.28 & 59.11 & 4.30 & 53 & 78 & 54 \\
\hline Lombardia & Como & 15.15 & 40.81 & 2.27 & 101 & 102 & 101 \\
\hline Lombardia & Cremona & 21.32 & 67.53 & 3.20 & 77 & 43 & 79 \\
\hline Lombardia & Lecco & 17.99 & 60.26 & 2.70 & 95 & 74 & 95 \\
\hline Lombardia & Lodi & 15.10 & 52.21 & 2.27 & 102 & 90 & 102 \\
\hline Lombardia & Mantova & 16.95 & 55.32 & 2.54 & 99 & 86 & 99 \\
\hline Lombardia & Milano & 37.88 & 90.11 & 6.21 & 23 & 5 & 23 \\
\hline Lombardia & Pavia & 21.91 & 53.82 & 3.52 & 74 & 87 & 75 \\
\hline Lombardia & Sondrio & 23.24 & 71.18 & 3.84 & 69 & 33 & 66 \\
\hline Lombardia & Varese & 21.46 & 60.78 & 3.37 & 75 & 72 & 76 \\
\hline Marche & Ancona & 20.31 & 59.99 & 3.05 & 81 & 75 & 82 \\
\hline Marche & Ascoli Piceno & 26.09 & 66.77 & 4.22 & 60 & 49 & 56 \\
\hline Marche & Macerata & 17.06 & 59.74 & 2.56 & 98 & 76 & 98 \\
\hline Marche & Pesaro Urbino & 31.64 & 49.69 & 4.92 & 32 & 97 & 45 \\
\hline Molise & Campobasso & 39.48 & 68.55 & 6.78 & 22 & 39 & 22 \\
\hline Molise & Isernia & 17.45 & 58.33 & 2.62 & 97 & 80 & 97 \\
\hline Piemonte & Alessandria & 30.86 & 74.94 & 4.93 & 38 & 25 & 44 \\
\hline Piemonte & Asti & 20.31 & 80.70 & 3.05 & 82 & 19 & 83 \\
\hline Piemonte & Biella & 19.90 & 69.58 & 2.98 & 83 & 37 & 85 \\
\hline Piemonte & Cuneo & 23.20 & 51.04 & 3.81 & 70 & 94 & 69 \\
\hline Piemonte & Novara & 28.92 & 84.37 & 4.69 & 44 & 17 & 49 \\
\hline Piemonte & Torino & 31.70 & 88.58 & 5.40 & 31 & 8 & 32 \\
\hline Piemonte & $\begin{array}{l}\text { Verbano Cusio } \\
\text { Ossola }\end{array}$ & 28.06 & 84.53 & 4.21 & 48 & 16 & 58 \\
\hline Piemonte & Vercelli & 31.60 & 65.11 & 5.11 & 34 & 56 & 39 \\
\hline Puglia & Bari & 23.84 & 59.25 & 4.18 & 68 & 77 & 60 \\
\hline Puglia & Brindisi & 47.09 & 64.99 & 85.69 & 13 & 57 & 6 \\
\hline Puglia & Foggia & 55.48 & 67.63 & 10.01 & 6 & 41 & 13 \\
\hline Puglia & Lecce & 25.62 & 73.69 & 4.00 & 63 & 26 & 63 \\
\hline Puglia & Taranto & 22.99 & 50.16 & 3.82 & 71 & 96 & 67 \\
\hline Sardegna & Cagliari & 48.62 & 89.64 & 7.75 & 11 & 7 & 20 \\
\hline Sardegna & Nuoro & 51.18 & 93.24 & 8.68 & 10 & 2 & 17 \\
\hline Sardegna & Oristano & 19.61 & 48.69 & 2.94 & 86 & 98 & 88 \\
\hline Sardegna & Sassari & 46.45 & 91.87 & 7.55 & 14 & 3 & 21 \\
\hline Sicilia & Agrigento & 26.00 & 45.84 & 8.76 & 61 & 100 & 16 \\
\hline Sicilia & Caltanissetta & 31.83 & 66.84 & 5.25 & 30 & 47 & 35 \\
\hline Sicilia & Catania & 45.16 & 53.17 & 40.28 & 17 & 88 & 11 \\
\hline Sicilia & Enna & 26.42 & 51.63 & 5.60 & 58 & 93 & 30 \\
\hline Sicilia & Messina & 27.29 & 62.83 & 5.88 & 52 & 64 & 27 \\
\hline Sicilia & Palermo & 64.87 & 71.71 & 93.83 & 3 & 28 & 1 \\
\hline Sicilia & Ragusa & 28.46 & 52.18 & 5.16 & 45 & 91 & 37 \\
\hline Sicilia & Siracusa & 52.87 & 65.79 & 88.32 & 9 & 54 & 4 \\
\hline
\end{tabular}


Table 16 (continued)

\begin{tabular}{|c|c|c|c|c|c|c|c|}
\hline Region & Province & OCI-Av & HOCI & LOCI & Rank-Av & Rank-HOCI & Rank-LOCI \\
\hline Sicilia & Trapani & 55.40 & 61.21 & 92.31 & 7 & 71 & 2 \\
\hline Toscana & Arezzo & 33.70 & 61.67 & 5.62 & 28 & 67 & 29 \\
\hline Toscana & Firenze & 39.68 & 67.77 & 6.21 & 21 & 40 & 24 \\
\hline Toscana & Grosseto & 29.35 & 66.62 & 4.98 & 43 & 50 & 43 \\
\hline Toscana & Livorno & 34.45 & 66.15 & 5.17 & 27 & 52 & 36 \\
\hline Toscana & Lucca & 20.37 & 76.53 & 3.06 & 80 & 24 & 81 \\
\hline Toscana & Massa Carrara & 27.34 & 57.91 & 4.75 & 51 & 81 & 47 \\
\hline Toscana & Pisa & 27.53 & 63.58 & 4.59 & 50 & 60 & 51 \\
\hline Toscana & Pistoia & 31.35 & 69.88 & 4.70 & 35 & 35 & 48 \\
\hline Toscana & Prato & 54.35 & 70.71 & 9.15 & 8 & 34 & 15 \\
\hline Toscana & Siena & 35.21 & 69.41 & 5.28 & 25 & 38 & 34 \\
\hline $\begin{array}{l}\text { Trentino-Alto } \\
\text { Adige }\end{array}$ & Bolzano & 21.08 & 51.65 & 3.54 & 78 & 92 & 74 \\
\hline $\begin{array}{l}\text { Trentino-Alto } \\
\text { Adige }\end{array}$ & Trento & 24.60 & 66.10 & 3.81 & 66 & 53 & 68 \\
\hline Umbria & Perugia & 15.84 & 61.53 & 2.38 & 100 & 69 & 100 \\
\hline Umbria & Terni & 20.97 & 71.29 & 3.15 & 79 & 32 & 80 \\
\hline Valle d'Aosta & Aosta & 45.21 & 90.73 & 7.78 & 16 & 4 & 19 \\
\hline Veneto & Belluno & 25.91 & 79.39 & 4.20 & 62 & 20 & 59 \\
\hline Veneto & Padova & 18.27 & 63.01 & 2.74 & 94 & 63 & 94 \\
\hline Veneto & Rovigo & 25.36 & 61.28 & 3.80 & 64 & 70 & 70 \\
\hline Veneto & Treviso & 14.26 & 40.62 & 2.21 & 103 & 103 & 103 \\
\hline Veneto & Venezia & 21.32 & 59.08 & 3.35 & 76 & 79 & 77 \\
\hline Veneto & Verona & 34.46 & 71.35 & 5.59 & 26 & 30 & 31 \\
\hline Veneto & Vicenza & 19.00 & 56.24 & 3.00 & 90 & 85 & 84 \\
\hline
\end{tabular}

OCI-Av, HOCI, and LOCI represent index outcomes with the equally-weighted, highest and lowest OCI scores, respectively. Rank-Av, Rank-HOCI, and Rank-LOCI represent rankings with the equallyweighted, highest and lowest OCI scores, respectively 
Table 17 Composite index scores and rankings in 2014 for the case 5

\begin{tabular}{|c|c|c|c|c|c|c|c|}
\hline Region & Province & OCI-Av & $\mathrm{HOCI}$ & LOCI & Rank-Av & Rank-HOCI & Rank-LOCI \\
\hline Abruzzo & Chieti & 0.00 & 0.00 & 0.00 & 30 & 30 & 24 \\
\hline Abruzzo & L'Aquila & 0.00 & 0.00 & 0.00 & 30 & 30 & 24 \\
\hline Abruzzo & Pescara & 0.00 & 0.00 & 0.00 & 30 & 30 & 24 \\
\hline Abruzzo & Teramo & 0.00 & 0.00 & 0.00 & 30 & 30 & 24 \\
\hline Basilicata & Matera & 0.00 & 0.00 & 0.00 & 30 & 30 & 24 \\
\hline Basilicata & Potenza & 8.01 & 16.34 & 0.00 & 25 & 20 & 24 \\
\hline Calabria & Catanzaro & 44.95 & 21.74 & 94.33 & 7 & 17 & 4 \\
\hline Calabria & Cosenza & 16.82 & 3.03 & 58.03 & 17 & 27 & 8 \\
\hline Calabria & Crotone & 42.90 & 35.35 & 7.15 & 8 & 12 & 13 \\
\hline Calabria & Reggio di Calabria & 77.67 & 77.17 & 96.53 & 1 & 1 & 1 \\
\hline Calabria & Vibo Valentia & 29.77 & 9.82 & 92.57 & 12 & 21 & 7 \\
\hline Campania & Avellino & 0.00 & 0.00 & 0.00 & 30 & 30 & 24 \\
\hline Campania & Benevento & 0.00 & 0.00 & 0.00 & 30 & 30 & 24 \\
\hline Campania & Caserta & 52.99 & 57.54 & 49.96 & 6 & 3 & 9 \\
\hline Campania & Napoli & 54.28 & 50.84 & 31.84 & 4 & 7 & 12 \\
\hline Campania & Salerno & 37.83 & 53.73 & 38.69 & 10 & 5 & 11 \\
\hline Emilia-Romagna & Bologna & 0.00 & 0.00 & 0.00 & 30 & 30 & 24 \\
\hline Emilia-Romagna & Ferrara & 0.00 & 0.00 & 0.00 & 30 & 30 & 24 \\
\hline Emilia-Romagna & Forlì Cesena & 0.00 & 0.00 & 0.00 & 30 & 30 & 24 \\
\hline Emilia-Romagna & Modena & 0.00 & 0.00 & 0.00 & 30 & 30 & 24 \\
\hline Emilia-Romagna & Parma & 0.00 & 0.00 & 0.00 & 30 & 30 & 24 \\
\hline Emilia-Romagna & Piacenza & 0.00 & 0.00 & 0.00 & 30 & 30 & 24 \\
\hline Emilia-Romagna & Ravenna & 0.00 & 0.00 & 0.00 & 30 & 30 & 24 \\
\hline Emilia-Romagna & Reggio Emilia & 0.00 & 0.00 & 0.00 & 30 & 30 & 24 \\
\hline Emilia-Romagna & Rimini & 0.00 & 0.00 & 0.00 & 30 & 30 & 24 \\
\hline $\begin{array}{l}\text { Friuli-Venezia } \\
\text { Giulia }\end{array}$ & Gorizia & 0.00 & 0.00 & 0.00 & 30 & 30 & 24 \\
\hline $\begin{array}{l}\text { Friuli-Venezia } \\
\text { Giulia }\end{array}$ & Pordenone & 0.00 & 0.00 & 0.00 & 30 & 30 & 24 \\
\hline $\begin{array}{l}\text { Friuli-Venezia } \\
\text { Giulia }\end{array}$ & Trieste & 0.00 & 0.00 & 0.00 & 30 & 30 & 24 \\
\hline $\begin{array}{l}\text { Friuli-Venezia } \\
\text { Giulia }\end{array}$ & Udine & 0.00 & 0.00 & 0.00 & 30 & 30 & 24 \\
\hline Lazio & Frosinone & 0.00 & 0.00 & 0.00 & 30 & 30 & 24 \\
\hline Lazio & Latina & 1.37 & 2.24 & 0.16 & 28 & 28 & 21 \\
\hline Lazio & Rieti & 0.00 & 0.00 & 0.00 & 30 & 30 & 24 \\
\hline Lazio & Roma & 0.88 & 1.72 & 0.02 & 29 & 29 & 23 \\
\hline Lazio & Viterbo & 0.00 & 0.00 & 0.00 & 30 & 30 & 24 \\
\hline Liguria & Genova & 0.00 & 0.00 & 0.00 & 30 & 30 & 24 \\
\hline Liguria & Imperia & 0.00 & 0.00 & 0.00 & 30 & 30 & 24 \\
\hline Liguria & La Spezia & 0.00 & 0.00 & 0.00 & 30 & 30 & 24 \\
\hline Liguria & Savona & 0.00 & 0.00 & 0.00 & 30 & 30 & 24 \\
\hline Lombardia & Bergamo & 0.00 & 0.00 & 0.00 & 30 & 30 & 24 \\
\hline
\end{tabular}


Table 17 (continued)

\begin{tabular}{|c|c|c|c|c|c|c|c|}
\hline Region & Province & OCI-Av & HOCI & LOCI & Rank-Av & Rank-HOCI & Rank-LOCI \\
\hline Lombardia & Brescia & 0.00 & 0.00 & 0.00 & 30 & 30 & 24 \\
\hline Lombardia & Como & 0.00 & 0.00 & 0.00 & 30 & 30 & 24 \\
\hline Lombardia & Cremona & 0.00 & 0.00 & 0.00 & 30 & 30 & 24 \\
\hline Lombardia & Lecco & 0.00 & 0.00 & 0.00 & 30 & 30 & 24 \\
\hline Lombardia & Lodi & 0.00 & 0.00 & 0.00 & 30 & 30 & 24 \\
\hline Lombardia & Mantova & 0.00 & 0.00 & 0.00 & 30 & 30 & 24 \\
\hline Lombardia & Milano & 1.90 & 3.88 & 0.00 & 27 & 26 & 24 \\
\hline Lombardia & Pavia & 0.00 & 0.00 & 0.00 & 30 & 30 & 24 \\
\hline Lombardia & Sondrio & 0.00 & 0.00 & 0.00 & 30 & 30 & 24 \\
\hline Lombardia & Varese & 0.00 & 0.00 & 0.00 & 30 & 30 & 24 \\
\hline Marche & Ancona & 0.00 & 0.00 & 0.00 & 30 & 30 & 24 \\
\hline Marche & Ascoli Piceno & 0.00 & 0.00 & 0.00 & 30 & 30 & 24 \\
\hline Marche & Macerata & 0.00 & 0.00 & 0.00 & 30 & 30 & 24 \\
\hline Marche & Pesaro Urbino & 0.00 & 0.00 & 0.00 & 30 & 30 & 24 \\
\hline Molise & Campobasso & 0.00 & 0.00 & 0.00 & 30 & 30 & 24 \\
\hline Molise & Isernia & 0.00 & 0.00 & 0.00 & 30 & 30 & 24 \\
\hline Piemonte & Alessandria & 0.00 & 0.00 & 0.00 & 30 & 30 & 24 \\
\hline Piemonte & Asti & 13.74 & 28.03 & 0.00 & 20 & 15 & 24 \\
\hline Piemonte & Biella & 0.00 & 0.00 & 0.00 & 30 & 30 & 24 \\
\hline Piemonte & Cuneo & 0.00 & 0.00 & 0.00 & 30 & 30 & 24 \\
\hline Piemonte & Novara & 0.00 & 0.00 & 0.00 & 30 & 30 & 24 \\
\hline Piemonte & Torino & 4.33 & 8.15 & 0.20 & 26 & 23 & 20 \\
\hline Piemonte & $\begin{array}{l}\text { Verbano Cusio } \\
\text { Ossola }\end{array}$ & 0.00 & 0.00 & 0.00 & 30 & 30 & 24 \\
\hline Piemonte & Vercelli & 0.00 & 0.00 & 0.00 & 30 & 30 & 24 \\
\hline Puglia & Bari & 10.35 & 8.52 & 1.49 & 23 & 22 & 17 \\
\hline Puglia & Brindisi & 53.39 & 57.60 & 92.70 & 5 & 2 & 6 \\
\hline Puglia & Foggia & 9.12 & 5.62 & 1.63 & 24 & 25 & 16 \\
\hline Puglia & Lecce & 18.72 & 38.19 & 0.00 & 15 & 11 & 24 \\
\hline Puglia & Taranto & 21.80 & 43.95 & 0.16 & 14 & 8 & 22 \\
\hline Sardegna & Cagliari & 0.00 & 0.00 & 0.00 & 30 & 30 & 24 \\
\hline Sardegna & Nuoro & 0.00 & 0.00 & 0.00 & 30 & 30 & 24 \\
\hline Sardegna & Oristano & 0.00 & 0.00 & 0.00 & 30 & 30 & 24 \\
\hline Sardegna & Sassari & 0.00 & 0.00 & 0.00 & 30 & 30 & 24 \\
\hline Sicilia & Agrigento & 17.35 & 28.46 & 2.08 & 16 & 14 & 15 \\
\hline Sicilia & Caltanissetta & 11.00 & 22.44 & 0.00 & 21 & 16 & 24 \\
\hline Sicilia & Catania & 38.97 & 42.86 & 39.77 & 9 & 10 & 10 \\
\hline Sicilia & Enna & 22.04 & 43.16 & 0.54 & 13 & 9 & 19 \\
\hline Sicilia & Messina & 15.33 & 28.87 & 0.72 & 19 & 13 & 18 \\
\hline Sicilia & Palermo & 58.06 & 53.47 & 95.66 & 2 & 6 & 2 \\
\hline Sicilia & Ragusa & 15.77 & 7.21 & 2.96 & 18 & 24 & 14 \\
\hline Sicilia & Siracusa & 36.54 & 20.93 & 93.39 & 11 & 19 & 5 \\
\hline
\end{tabular}


Table 17 (continued)

\begin{tabular}{|c|c|c|c|c|c|c|c|}
\hline Region & Province & OCI-Av & HOCI & LOCI & Rank-Av & Rank-HOCI & Rank-LOCI \\
\hline Sicilia & Trapani & 56.93 & 57.14 & 95.00 & 3 & 4 & 3 \\
\hline Toscana & Arezzo & 0.00 & 0.00 & 0.00 & 30 & 30 & 24 \\
\hline Toscana & Firenze & 0.00 & 0.00 & 0.00 & 30 & 30 & 24 \\
\hline Toscana & Grosseto & 0.00 & 0.00 & 0.00 & 30 & 30 & 24 \\
\hline Toscana & Livorno & 0.00 & 0.00 & 0.00 & 30 & 30 & 24 \\
\hline Toscana & Lucca & 0.00 & 0.00 & 0.00 & 30 & 30 & 24 \\
\hline Toscana & Massa Carrara & 0.00 & 0.00 & 0.00 & 30 & 30 & 24 \\
\hline Toscana & Pisa & 0.00 & 0.00 & 0.00 & 30 & 30 & 24 \\
\hline Toscana & Pistoia & 10.36 & 21.13 & 0.00 & 22 & 18 & 24 \\
\hline Toscana & Prato & 0.00 & 0.00 & 0.00 & 30 & 30 & 24 \\
\hline Toscana & Siena & 0.00 & 0.00 & 0.00 & 30 & 30 & 24 \\
\hline $\begin{array}{l}\text { Trentino-Alto } \\
\text { Adige }\end{array}$ & Bolzano & 0.00 & 0.00 & 0.00 & 30 & 30 & 24 \\
\hline $\begin{array}{l}\text { Trentino-Alto } \\
\text { Adige }\end{array}$ & Trento & 0.00 & 0.00 & 0.00 & 30 & 30 & 24 \\
\hline Umbria & Perugia & 0.00 & 0.00 & 0.00 & 30 & 30 & 24 \\
\hline Umbria & Terni & 0.00 & 0.00 & 0.00 & 30 & 30 & 24 \\
\hline Valle d'Aosta & Aosta & 0.00 & 0.00 & 0.00 & 30 & 30 & 24 \\
\hline Veneto & Belluno & 0.00 & 0.00 & 0.00 & 30 & 30 & 24 \\
\hline Veneto & Padova & 0.00 & 0.00 & 0.00 & 30 & 30 & 24 \\
\hline Veneto & Rovigo & 0.00 & 0.00 & 0.00 & 30 & 30 & 24 \\
\hline Veneto & Treviso & 0.00 & 0.00 & 0.00 & 30 & 30 & 24 \\
\hline Veneto & Venezia & 0.00 & 0.00 & 0.00 & 30 & 30 & 24 \\
\hline Veneto & Verona & 0.00 & 0.00 & 0.00 & 30 & 30 & 24 \\
\hline Veneto & Vicenza & 0.00 & 0.00 & 0.00 & 30 & 30 & 24 \\
\hline
\end{tabular}

OCI-Av, HOCI, and LOCI represent index outcomes with the equally-weighted, highest and lowest OCI scores, respectively. Rank-Av, Rank-HOCI, and Rank-LOCI represent rankings with the equallyweighted, highest and lowest OCI scores, respectively 
Table 18 Composite index scores and rankings in 2014 for the case 6

\begin{tabular}{|c|c|c|c|c|c|c|c|}
\hline Region & Province & OCI-Av & HOCI & LOCI & Rank-Av & Rank-HOCI & Rank-LOCI \\
\hline Abruzzo & Chieti & 19.86 & 58.69 & 2.46 & 44 & 47 & 47 \\
\hline Abruzzo & L'Aquila & 16.76 & 54.19 & 2.25 & 63 & 58 & 58 \\
\hline Abruzzo & Pescara & 23.59 & 81.33 & 2.60 & 32 & 10 & 45 \\
\hline Abruzzo & Teramo & 18.60 & 63.22 & 2.35 & 50 & 37 & 53 \\
\hline Basilicata & Matera & 20.12 & 51.89 & 3.29 & 41 & 66 & 32 \\
\hline Basilicata & Potenza & 26.68 & 64.16 & 3.81 & 26 & 34 & 27 \\
\hline Calabria & Catanzaro & 54.58 & 75.43 & 88.61 & 4 & 19 & 4 \\
\hline Calabria & Cosenza & 38.76 & 80.97 & 56.67 & 18 & 11 & 8 \\
\hline Calabria & Crotone & 56.99 & 63.61 & 14.61 & 2 & 35 & 13 \\
\hline Calabria & Reggio di Calabria & 73.21 & 86.97 & 90.79 & 1 & 4 & 1 \\
\hline Calabria & Vibo Valentia & 38.77 & 79.72 & 84.82 & 17 & 13 & 7 \\
\hline Campania & Avellino & 20.78 & 60.69 & 3.25 & 40 & 42 & 34 \\
\hline Campania & Benevento & 38.89 & 88.41 & 6.40 & 16 & 2 & 17 \\
\hline Campania & Caserta & 56.28 & 88.13 & 50.29 & 3 & 3 & 9 \\
\hline Campania & Napoli & 53.65 & 81.94 & 31.18 & 5 & 9 & 12 \\
\hline Campania & Salerno & 44.91 & 83.49 & 38.68 & 10 & 7 & 11 \\
\hline Emilia-Romagna & Bologna & 24.72 & 84.97 & 2.85 & 29 & 5 & 38 \\
\hline Emilia-Romagna & Ferrara & 10.43 & 36.76 & 1.10 & 91 & 92 & 93 \\
\hline Emilia-Romagna & Forlì Cesena & 17.30 & 60.66 & 2.08 & 58 & 43 & 62 \\
\hline Emilia-Romagna & Modena & 9.56 & 38.17 & 0.90 & 94 & 89 & 97 \\
\hline Emilia-Romagna & Parma & 16.21 & 58.00 & 2.01 & 68 & 50 & 64 \\
\hline Emilia-Romagna & Piacenza & 12.93 & 48.67 & 1.55 & 86 & 72 & 83 \\
\hline Emilia-Romagna & Ravenna & 22.82 & 74.17 & 2.94 & 35 & 23 & 37 \\
\hline Emilia-Romagna & Reggio Emilia & 14.16 & 50.66 & 1.65 & 78 & 70 & 80 \\
\hline Emilia-Romagna & Rimini & 20.95 & 80.04 & 2.23 & 39 & 12 & 60 \\
\hline $\begin{array}{l}\text { Friuli-Venezia } \\
\text { Giulia }\end{array}$ & Gorizia & 3.89 & 17.66 & 0.26 & 103 & 103 & 103 \\
\hline $\begin{array}{l}\text { Friuli-Venezia } \\
\text { Giulia }\end{array}$ & Pordenone & 16.29 & 58.04 & 1.58 & 67 & 49 & 81 \\
\hline $\begin{array}{l}\text { Friuli-Venezia } \\
\text { Giulia }\end{array}$ & Trieste & 13.37 & 45.22 & 1.94 & 85 & 80 & 66 \\
\hline $\begin{array}{l}\text { Friuli-Venezia } \\
\text { Giulia }\end{array}$ & Udine & 8.40 & 25.06 & 1.03 & 99 & 101 & 96 \\
\hline Lazio & Frosinone & 23.45 & 63.54 & 3.50 & 33 & 36 & 30 \\
\hline Lazio & Latina & 28.49 & 65.68 & 5.65 & 25 & 32 & 19 \\
\hline Lazio & Rieti & 18.28 & 51.78 & 2.66 & 52 & 67 & 42 \\
\hline Lazio & Roma & 19.17 & 57.92 & 2.62 & 47 & 52 & 43 \\
\hline Lazio & Viterbo & 19.85 & 59.97 & 3.06 & 45 & 44 & 35 \\
\hline Liguria & Genova & 16.43 & 56.44 & 1.81 & 66 & 55 & 74 \\
\hline Liguria & Imperia & 26.11 & 74.38 & 4.14 & 27 & 21 & 26 \\
\hline Liguria & La Spezia & 15.30 & 49.88 & 1.84 & 73 & 71 & 70 \\
\hline Liguria & Savona & 18.23 & 57.63 & 2.77 & 53 & 53 & 40 \\
\hline Lombardia & Bergamo & 15.64 & 45.47 & 2.40 & 70 & 79 & 51 \\
\hline
\end{tabular}


Table 18 (continued)

\begin{tabular}{|c|c|c|c|c|c|c|c|}
\hline Region & Province & OCI-Av & HOCI & LOCI & Rank-Av & Rank-HOCI & Rank-LOCI \\
\hline Lombardia & Brescia & 13.98 & 46.51 & 1.82 & 79 & 77 & 71 \\
\hline Lombardia & Como & 14.89 & 48.35 & 2.15 & 74 & 73 & 61 \\
\hline Lombardia & Cremona & 17.56 & 62.56 & 1.67 & 56 & 38 & 78 \\
\hline Lombardia & Lecco & 9.42 & 40.67 & 0.77 & 96 & 86 & 100 \\
\hline Lombardia & Lodi & 10.41 & 37.22 & 1.38 & 92 & 91 & 86 \\
\hline Lombardia & Mantova & 19.22 & 53.56 & 3.44 & 46 & 61 & 31 \\
\hline Lombardia & Milano & 22.20 & 68.81 & 2.76 & 36 & 27 & 41 \\
\hline Lombardia & Pavia & 11.70 & 41.73 & 1.46 & 88 & 85 & 85 \\
\hline Lombardia & Sondrio & 13.75 & 51.67 & 1.66 & 81 & 68 & 79 \\
\hline Lombardia & Varese & 15.59 & 53.57 & 1.75 & 72 & 60 & 76 \\
\hline Marche & Ancona & 24.41 & 51.64 & 3.28 & 30 & 69 & 33 \\
\hline Marche & Ascoli Piceno & 11.50 & 25.70 & 2.07 & 90 & 99 & 63 \\
\hline Marche & Macerata & 22.10 & 70.49 & 2.61 & 37 & 26 & 44 \\
\hline Marche & Pesaro Urbino & 13.53 & 45.18 & 1.85 & 84 & 81 & 69 \\
\hline Molise & Campobasso & 15.64 & 43.38 & 2.24 & 71 & 83 & 59 \\
\hline Molise & Isernia & 32.89 & 84.55 & 5.34 & 22 & 6 & 21 \\
\hline Piemonte & Alessandria & 18.15 & 51.91 & 2.35 & 54 & 65 & 54 \\
\hline Piemonte & Asti & 23.24 & 53.36 & 1.72 & 34 & 62 & 77 \\
\hline Piemonte & Biella & 16.48 & 72.07 & 1.27 & 65 & 24 & 89 \\
\hline Piemonte & Cuneo & 7.73 & 28.69 & 0.85 & 100 & 98 & 99 \\
\hline Piemonte & Novara & 18.82 & 58.52 & 2.31 & 49 & 48 & 55 \\
\hline Piemonte & Torino & 20.04 & 59.70 & 2.44 & 43 & 45 & 49 \\
\hline Piemonte & $\begin{array}{l}\text { Verbano Cusio } \\
\text { Ossola }\end{array}$ & 14.18 & 61.54 & 1.12 & 77 & 41 & 92 \\
\hline Piemonte & Vercelli & 12.47 & 53.25 & 1.08 & 87 & 63 & 94 \\
\hline Puglia & Bari & 30.41 & 74.54 & 5.42 & 24 & 20 & 20 \\
\hline Puglia & Brindisi & 51.88 & 71.09 & 85.98 & 6 & 25 & 6 \\
\hline Puglia & Foggia & 39.08 & 95.22 & 7.67 & 15 & 1 & 16 \\
\hline Puglia & Lecce & 43.97 & 83.17 & 5.09 & 11 & 8 & 22 \\
\hline Puglia & Taranto & 39.11 & 76.62 & 4.47 & 14 & 16 & 25 \\
\hline Sardegna & Cagliari & 17.34 & 64.63 & 1.95 & 57 & 33 & 65 \\
\hline Sardegna & Nuoro & 18.59 & 62.38 & 2.41 & 51 & 39 & 50 \\
\hline Sardegna & Oristano & 8.85 & 35.92 & 0.89 & 98 & 94 & 98 \\
\hline Sardegna & Sassari & 19.11 & 76.59 & 1.79 & 48 & 17 & 75 \\
\hline Sicilia & Agrigento & 35.30 & 48.31 & 7.92 & 21 & 74 & 15 \\
\hline Sicilia & Caltanissetta & 38.53 & 65.78 & 5.72 & 19 & 31 & 18 \\
\hline Sicilia & Catania & 47.95 & 79.57 & 39.89 & 8 & 14 & 10 \\
\hline Sicilia & Enna & 37.45 & 75.49 & 4.73 & 20 & 18 & 24 \\
\hline Sicilia & Messina & 32.12 & 67.97 & 5.07 & 23 & 28 & 23 \\
\hline Sicilia & Palermo & 50.46 & 56.08 & 89.81 & 7 & 56 & 2 \\
\hline Sicilia & Ragusa & 41.13 & 67.66 & 8.18 & 13 & 29 & 14 \\
\hline Sicilia & Siracusa & 41.18 & 77.48 & 86.29 & 12 & 15 & 5 \\
\hline
\end{tabular}


Table 18 (continued)

\begin{tabular}{|c|c|c|c|c|c|c|c|}
\hline Region & Province & OCI-Av & HOCI & LOCI & Rank-Av & Rank-HOCI & Rank-LOCI \\
\hline Sicilia & Trapani & 47.92 & 59.63 & 88.88 & 9 & 46 & 3 \\
\hline Toscana & Arezzo & 17.25 & 55.06 & 2.27 & 59 & 57 & 56 \\
\hline Toscana & Firenze & 20.04 & 66.41 & 2.37 & 42 & 30 & 52 \\
\hline Toscana & Grosseto & 16.53 & 47.43 & 2.80 & 64 & 75 & 39 \\
\hline Toscana & Livorno & 14.20 & 54.08 & 1.48 & 76 & 59 & 84 \\
\hline Toscana & Lucca & 15.67 & 57.15 & 1.87 & 69 & 54 & 68 \\
\hline Toscana & Massa Carrara & 10.15 & 25.38 & 1.55 & 93 & 100 & 82 \\
\hline Toscana & Pisa & 13.65 & 53.14 & 1.37 & 83 & 64 & 87 \\
\hline Toscana & Pistoia & 25.11 & 74.23 & 1.82 & 28 & 22 & 72 \\
\hline Toscana & Prato & 22.03 & 62.02 & 3.61 & 38 & 40 & 29 \\
\hline Toscana & Siena & 23.94 & 43.78 & 3.68 & 31 & 82 & 28 \\
\hline $\begin{array}{l}\text { Trentino-Alto } \\
\text { Adige }\end{array}$ & Bolzano & 14.37 & 39.54 & 1.92 & 75 & 87 & 67 \\
\hline $\begin{array}{l}\text { Trentino-Alto } \\
\text { Adige }\end{array}$ & Trento & 9.48 & 32.76 & 1.24 & 95 & 95 & 90 \\
\hline Umbria & Perugia & 17.01 & 46.64 & 2.26 & 61 & 76 & 57 \\
\hline Umbria & Terni & 16.97 & 36.41 & 2.45 & 62 & 93 & 48 \\
\hline Valle d'Aosta & Aosta & 13.83 & 57.92 & 1.23 & 80 & 51 & 91 \\
\hline Veneto & Belluno & 6.70 & 32.23 & 0.32 & 101 & 96 & 102 \\
\hline Veneto & Padova & 11.51 & 38.16 & 1.35 & 89 & 90 & 88 \\
\hline Veneto & Rovigo & 17.57 & 39.39 & 3.03 & 55 & 88 & 36 \\
\hline Veneto & Treviso & 5.78 & 23.95 & 0.47 & 102 & 102 & 101 \\
\hline Veneto & Venezia & 13.70 & 41.97 & 1.81 & 82 & 84 & 73 \\
\hline Veneto & Verona & 17.14 & 45.54 & 2.49 & 60 & 78 & 46 \\
\hline Veneto & Vicenza & 8.98 & 30.26 & 1.06 & 97 & 97 & 95 \\
\hline
\end{tabular}

OCI-Av, HOCI, and LOCI represent index outcomes with the equally-weighted, highest and lowest OCI scores, respectively. Rank-Av, Rank-HOCI, and Rank-LOCI represent rankings with the equallyweighted, highest and lowest OCI scores, respectively 
Table 19 Composite index scores and rankings in 2014 for the case 7

\begin{tabular}{|c|c|c|c|c|c|c|c|}
\hline Region & Province & OCI-Av & $\mathrm{HOCI}$ & LOCI & Rank-Av & Rank-HOCI & Rank-LOCI \\
\hline Abruzzo & Chieti & 24.67 & 42.84 & 5.61 & 52 & 79 & 42 \\
\hline Abruzzo & L'Aquila & 25.62 & 52.96 & 5.48 & 48 & 54 & 44 \\
\hline Abruzzo & Pescara & 32.93 & 81.51 & 5.73 & 22 & 7 & 40 \\
\hline Abruzzo & Teramo & 22.00 & 62.65 & 4.59 & 60 & 33 & 54 \\
\hline Basilicata & Matera & 17.10 & 42.17 & 3.19 & 84 & 81 & 84 \\
\hline Basilicata & Potenza & 29.82 & 45.31 & 4.02 & 32 & 72 & 65 \\
\hline Calabria & Catanzaro & 49.88 & 66.95 & 84.94 & 4 & 26 & 3 \\
\hline Calabria & Cosenza & 36.17 & 60.79 & 53.97 & 18 & 37 & 8 \\
\hline Calabria & Crotone & 44.89 & 57.99 & 13.06 & 9 & 42 & 13 \\
\hline Calabria & Reggio di Calabria & 61.48 & 65.82 & 87.51 & 2 & 27 & 1 \\
\hline Calabria & Vibo Valentia & 38.76 & 57.22 & 81.17 & 14 & 46 & 7 \\
\hline Campania & Avellino & 29.91 & 41.15 & 6.37 & 30 & 84 & 32 \\
\hline Campania & Benevento & 31.53 & 59.74 & 6.73 & 25 & 39 & 29 \\
\hline Campania & Caserta & 54.32 & 64.74 & 50.07 & 3 & 29 & 9 \\
\hline Campania & Napoli & 63.36 & 72.93 & 35.98 & 1 & 16 & 12 \\
\hline Campania & Salerno & 45.89 & 57.17 & 38.50 & 5 & 47 & 10 \\
\hline Emilia-Romagna & Bologna & 27.42 & 77.21 & 4.36 & 42 & 9 & 59 \\
\hline Emilia-Romagna & Ferrara & 16.71 & 43.63 & 2.77 & 87 & 75 & 90 \\
\hline Emilia-Romagna & Forlì Cesena & 24.35 & 48.82 & 3.18 & 54 & 65 & 85 \\
\hline Emilia-Romagna & Modena & 19.99 & 46.51 & 3.46 & 69 & 68 & 77 \\
\hline Emilia-Romagna & Parma & 25.30 & 52.12 & 4.67 & 50 & 56 & 51 \\
\hline Emilia-Romagna & Piacenza & 14.89 & 39.53 & 2.13 & 92 & 90 & 98 \\
\hline Emilia-Romagna & Ravenna & 26.31 & 89.02 & 5.77 & 45 & 3 & 38 \\
\hline Emilia-Romagna & Reggio Emilia & 23.08 & 45.59 & 3.12 & 58 & 71 & 86 \\
\hline Emilia-Romagna & Rimini & 31.40 & 74.50 & 5.98 & 27 & 12 & 35 \\
\hline $\begin{array}{l}\text { Friuli-Venezia } \\
\text { Giulia }\end{array}$ & Gorizia & 19.50 & 25.56 & 6.17 & 72 & 102 & 34 \\
\hline $\begin{array}{l}\text { Friuli-Venezia } \\
\text { Giulia }\end{array}$ & Pordenone & 17.97 & 35.55 & 1.66 & 77 & 93 & 102 \\
\hline $\begin{array}{l}\text { Friuli-Venezia } \\
\text { Giulia }\end{array}$ & Trieste & 22.93 & 49.42 & 3.59 & 59 & 63 & 73 \\
\hline $\begin{array}{l}\text { Friuli-Venezia } \\
\text { Giulia }\end{array}$ & Udine & 11.38 & 30.34 & 2.92 & 102 & 99 & 88 \\
\hline Lazio & Frosinone & 31.63 & 50.89 & 6.91 & 24 & 60 & 25 \\
\hline Lazio & Latina & 33.01 & 63.19 & 6.81 & 21 & 31 & 28 \\
\hline Lazio & Rieti & 21.49 & 46.49 & 4.92 & 64 & 69 & 49 \\
\hline Lazio & Roma & 30.89 & 84.37 & 7.74 & 29 & 4 & 19 \\
\hline Lazio & Viterbo & 21.32 & 73.03 & 4.58 & 65 & 15 & 55 \\
\hline Liguria & Genova & 29.33 & 72.06 & 5.14 & 35 & 17 & 46 \\
\hline Liguria & Imperia & 31.44 & 94.24 & 6.89 & 26 & 2 & 26 \\
\hline Liguria & La Spezia & 26.20 & 58.30 & 4.11 & 46 & 40 & 63 \\
\hline Liguria & Savona & 19.80 & 57.67 & 4.60 & 71 & 44 & 53 \\
\hline Lombardia & Bergamo & 17.73 & 42.64 & 3.65 & 79 & 80 & 71 \\
\hline
\end{tabular}


Table 19 (continued)

\begin{tabular}{|c|c|c|c|c|c|c|c|}
\hline Region & Province & OCI-Av & HOCI & LOCI & Rank-Av & Rank-HOCI & Rank-LOCI \\
\hline Lombardia & Brescia & 23.32 & 60.55 & 4.92 & 57 & 38 & 48 \\
\hline Lombardia & Como & 14.06 & 43.01 & 2.51 & 97 & 78 & 94 \\
\hline Lombardia & Cremona & 16.89 & 51.44 & 2.24 & 86 & 59 & 95 \\
\hline Lombardia & Lecco & 12.68 & 35.08 & 1.74 & 100 & 94 & 100 \\
\hline Lombardia & Lodi & 12.53 & 37.70 & 2.16 & 101 & 92 & 96 \\
\hline Lombardia & Mantova & 14.78 & 29.19 & 1.97 & 94 & 100 & 99 \\
\hline Lombardia & Milano & 29.90 & 74.37 & 6.87 & 31 & 13 & 27 \\
\hline Lombardia & Pavia & 16.60 & 40.76 & 3.50 & 88 & 86 & 76 \\
\hline Lombardia & Sondrio & 18.15 & 46.52 & 4.16 & 75 & 67 & 62 \\
\hline Lombardia & Varese & 19.42 & 68.30 & 4.38 & 73 & 23 & 58 \\
\hline Marche & Ancona & 20.46 & 58.28 & 3.54 & 67 & 41 & 75 \\
\hline Marche & Ascoli Piceno & 19.89 & 40.66 & 4.91 & 70 & 87 & 50 \\
\hline Marche & Macerata & 21.16 & 76.74 & 4.00 & 66 & 10 & 66 \\
\hline Marche & Pesaro Urbino & 21.62 & 43.14 & 3.78 & 63 & 77 & 69 \\
\hline Molise & Campobasso & 26.70 & 43.48 & 7.32 & 43 & 76 & 21 \\
\hline Molise & Isernia & 27.62 & 57.86 & 4.10 & 41 & 43 & 64 \\
\hline Piemonte & Alessandria & 23.46 & 49.15 & 4.53 & 55 & 64 & 57 \\
\hline Piemonte & Asti & 17.22 & 42.12 & 1.70 & 83 & 82 & 101 \\
\hline Piemonte & Biella & 18.00 & 64.60 & 2.73 & 76 & 30 & 93 \\
\hline Piemonte & Cuneo & 14.34 & 34.13 & 3.56 & 96 & 96 & 74 \\
\hline Piemonte & Novara & 15.57 & 42.11 & 3.40 & 91 & 83 & 78 \\
\hline Piemonte & Torino & 21.65 & 54.95 & 3.97 & 62 & 50 & 67 \\
\hline Piemonte & $\begin{array}{l}\text { Verbano Cusio } \\
\text { Ossola }\end{array}$ & 23.41 & 69.20 & 3.76 & 56 & 20 & 70 \\
\hline Piemonte & Vercelli & 21.71 & 52.64 & 4.61 & 61 & 55 & 52 \\
\hline Puglia & Bari & 27.90 & 62.13 & 6.51 & 40 & 34 & 31 \\
\hline Puglia & Brindisi & 44.89 & 67.12 & 82.19 & 8 & 25 & 6 \\
\hline Puglia & Foggia & 45.50 & 67.69 & 11.66 & 6 & 24 & 14 \\
\hline Puglia & Lecce & 39.01 & 68.86 & 5.61 & 13 & 21 & 43 \\
\hline Puglia & Taranto & 35.71 & 61.88 & 4.55 & 19 & 35 & 56 \\
\hline Sardegna & Cagliari & 37.55 & 81.70 & 7.85 & 16 & 6 & 18 \\
\hline Sardegna & Nuoro & 34.39 & 65.49 & 8.99 & 20 & 28 & 16 \\
\hline Sardegna & Oristano & 17.54 & 41.03 & 2.76 & 80 & 85 & 91 \\
\hline Sardegna & Sassari & 37.47 & 94.36 & 8.32 & 17 & 1 & 17 \\
\hline Sicilia & Agrigento & 24.58 & 39.03 & 5.81 & 53 & 91 & 36 \\
\hline Sicilia & Caltanissetta & 26.37 & 39.63 & 5.37 & 44 & 89 & 45 \\
\hline Sicilia & Catania & 45.12 & 62.88 & 38.44 & 7 & 32 & 11 \\
\hline Sicilia & Enna & 32.60 & 54.37 & 5.62 & 23 & 51 & 41 \\
\hline Sicilia & Messina & 28.34 & 50.61 & 4.99 & 38 & 61 & 47 \\
\hline Sicilia & Palermo & 42.52 & 49.95 & 85.23 & 11 & 62 & 2 \\
\hline Sicilia & Ragusa & 28.26 & 53.28 & 7.00 & 39 & 52 & 24 \\
\hline Sicilia & Siracusa & 44.33 & 80.26 & 84.70 & 10 & 8 & 4 \\
\hline
\end{tabular}


Table 19 (continued)

\begin{tabular}{|c|c|c|c|c|c|c|c|}
\hline Region & Province & OCI-Av & HOCI & LOCI & Rank-Av & Rank-HOCI & Rank-LOCI \\
\hline Sicilia & Trapani & 37.71 & 48.66 & 83.64 & 15 & 66 & 5 \\
\hline Toscana & Arezzo & 28.35 & 73.04 & 7.32 & 37 & 14 & 22 \\
\hline Toscana & Firenze & 29.68 & 75.51 & 5.80 & 34 & 11 & 37 \\
\hline Toscana & Grosseto & 28.51 & 57.07 & 7.19 & 36 & 48 & 23 \\
\hline Toscana & Livorno & 25.00 & 69.80 & 4.31 & 51 & 19 & 60 \\
\hline Toscana & Lucca & 17.36 & 51.45 & 2.82 & 81 & 58 & 89 \\
\hline Toscana & Massa Carrara & 18.68 & 53.04 & 6.61 & 74 & 53 & 30 \\
\hline Toscana & Pisa & 25.80 & 68.47 & 6.20 & 47 & 22 & 33 \\
\hline Toscana & Pistoia & 30.91 & 61.35 & 3.31 & 28 & 36 & 81 \\
\hline Toscana & Prato & 40.94 & 84.32 & 10.80 & 12 & 5 & 15 \\
\hline Toscana & Siena & 20.19 & 33.76 & 2.75 & 68 & 97 & 92 \\
\hline $\begin{array}{l}\text { Trentino-Alto } \\
\text { Adige }\end{array}$ & Bolzano & 13.70 & 40.30 & 3.81 & 98 & 88 & 68 \\
\hline $\begin{array}{l}\text { Trentino-Alto } \\
\text { Adige }\end{array}$ & Trento & 14.66 & 44.64 & 3.34 & 95 & 74 & 80 \\
\hline Umbria & Perugia & 15.86 & 56.97 & 3.23 & 90 & 49 & 83 \\
\hline Umbria & Terni & 17.06 & 51.94 & 3.59 & 85 & 57 & 72 \\
\hline Valle d'Aosta & Aosta & 25.35 & 57.35 & 7.40 & 49 & 45 & 20 \\
\hline Veneto & Belluno & 14.85 & 34.37 & 3.29 & 93 & 95 & 82 \\
\hline Veneto & Padova & 17.87 & 70.11 & 4.21 & 78 & 18 & 61 \\
\hline Veneto & Rovigo & 13.58 & 26.75 & 2.15 & 99 & 101 & 97 \\
\hline Veneto & Treviso & 8.88 & 24.08 & 1.60 & 103 & 103 & 103 \\
\hline Veneto & Venezia & 15.90 & 46.15 & 3.35 & 89 & 70 & 79 \\
\hline Veneto & Verona & 29.78 & 44.82 & 5.76 & 33 & 73 & 39 \\
\hline Veneto & Vicenza & 17.28 & 31.19 & 3.04 & 82 & 98 & 87 \\
\hline
\end{tabular}

OCI-Av, HOCI, and LOCI represent index outcomes with the equally-weighted, highest and lowest OCI scores, respectively. Rank-Av, Rank-HOCI, and Rank-LOCI represent rankings with the equallyweighted, highest and lowest OCI scores, respectively 
Table 20 Composite index scores and rankings in 2014 when 17 indicators are used to construct indices

\begin{tabular}{|c|c|c|c|c|c|c|c|}
\hline Region & Province & OCI-Av & HOCI & LOCI & Rank-Av & Rank-HOCI & Rank-LOCI \\
\hline Abruzzo & Chieti & 29.56 & 62.06 & 3.29 & 65 & 69 & 29 \\
\hline Abruzzo & L'Aquila & 30.65 & 57.63 & 2.11 & 61 & 80 & 42 \\
\hline Abruzzo & Pescara & 43.35 & 84.49 & 1.00 & 13 & 8 & 63 \\
\hline Abruzzo & Teramo & 27.30 & 63.51 & 1.04 & 74 & 62 & 61 \\
\hline Basilicata & Matera & 23.05 & 53.40 & 0.00 & 91 & 93 & 76 \\
\hline Basilicata & Potenza & 37.20 & 71.82 & 1.92 & 36 & 30 & 47 \\
\hline Calabria & Catanzaro & 51.05 & 83.22 & 80.25 & 4 & 11 & 5 \\
\hline Calabria & Cosenza & 37.44 & 66.43 & 47.50 & 35 & 49 & 9 \\
\hline Calabria & Crotone & 45.33 & 54.01 & 12.01 & 9 & 91 & 13 \\
\hline Calabria & Reggio di Calabria & 64.06 & 80.06 & 91.06 & 1 & 15 & 1 \\
\hline Calabria & Vibo_Valentia & 42.93 & 88.27 & 76.33 & 14 & 5 & 7 \\
\hline Campania & Avellino & 34.69 & 75.59 & 3.01 & 45 & 23 & 33 \\
\hline Campania & Benevento & 45.43 & 66.81 & 2.28 & 8 & 47 & 41 \\
\hline Campania & Caserta & 54.63 & 64.96 & 51.08 & 3 & 55 & 8 \\
\hline Campania & Napoli & 57.40 & 78.59 & 39.07 & 2 & 19 & 11 \\
\hline Campania & Salerno & 45.74 & 79.89 & 39.43 & 7 & 16 & 10 \\
\hline Emilia-Romagna & Bologna & 38.30 & 83.81 & 0.32 & 30 & 9 & 75 \\
\hline Emilia-Romagna & Ferrara & 25.03 & 67.62 & 0.00 & 83 & 43 & 76 \\
\hline Emilia-Romagna & Forlì_Cesena & 34.37 & 64.25 & 0.00 & 47 & 60 & 76 \\
\hline Emilia-Romagna & Modena & 25.16 & 59.85 & 0.46 & 81 & 77 & 72 \\
\hline Emilia-Romagna & Parma & 30.79 & 70.69 & 1.46 & 58 & 34 & 56 \\
\hline Emilia-Romagna & Piacenza & 25.42 & 52.38 & 0.00 & 80 & 94 & 76 \\
\hline Emilia-Romagna & Ravenna & 42.12 & 79.16 & 0.83 & 18 & 18 & 67 \\
\hline Emilia-Romagna & Reggio_Emilia & 27.60 & 62.22 & 0.00 & 71 & 68 & 76 \\
\hline Emilia-Romagna & Rimini & 39.24 & 83.02 & 1.94 & 27 & 13 & 46 \\
\hline $\begin{array}{l}\text { Friuli-Venezia } \\
\text { Giulia }\end{array}$ & Gorizia & 24.24 & 67.74 & 4.59 & 89 & 42 & 24 \\
\hline $\begin{array}{l}\text { Friuli-Venezia } \\
\text { Giulia }\end{array}$ & Pordenone & 21.88 & 52.29 & 0.00 & 94 & 95 & 76 \\
\hline $\begin{array}{l}\text { Friuli-Venezia } \\
\text { Giulia }\end{array}$ & Trieste & 36.85 & 78.39 & 0.00 & 38 & 20 & 76 \\
\hline $\begin{array}{l}\text { Friuli-Venezia } \\
\text { Giulia }\end{array}$ & Udine & 18.47 & 51.80 & 1.20 & 102 & 96 & 58 \\
\hline Lazio & Frosinone & 37.44 & 67.29 & 3.25 & 34 & 44 & 30 \\
\hline Lazio & Latina & 39.16 & 72.03 & 0.95 & 28 & 28 & 64 \\
\hline Lazio & Rieti & 25.93 & 54.42 & 2.03 & 77 & 89 & 44 \\
\hline Lazio & Roma & 38.74 & 67.03 & 2.69 & 29 & 45 & 37 \\
\hline Lazio & Viterbo & 30.77 & 64.35 & 0.00 & 60 & 58 & 76 \\
\hline Liguria & Genova & 37.82 & 73.87 & 0.37 & 32 & 25 & 73 \\
\hline Liguria & Imperia & 38.03 & 97.39 & 0.00 & 31 & 2 & 76 \\
\hline Liguria & La Spezia & 31.84 & 60.27 & 0.00 & 55 & 74 & 76 \\
\hline Liguria & Savona & 30.21 & 83.74 & 1.14 & 62 & 10 & 60 \\
\hline Lombardia & Bergamo & 27.48 & 64.45 & 0.88 & 72 & 56 & 66 \\
\hline
\end{tabular}


Table 20 (continued)

\begin{tabular}{|c|c|c|c|c|c|c|c|}
\hline Region & Province & OCI-Av & HOCI & LOCI & Rank-Av & Rank-HOCI & Rank-LOCI \\
\hline Lombardia & Brescia & 30.14 & 62.90 & 1.03 & 64 & 65 & 62 \\
\hline Lombardia & Como & 18.63 & 41.09 & 0.00 & 101 & 102 & 76 \\
\hline Lombardia & Cremona & 28.72 & 68.10 & 0.00 & 67 & 37 & 76 \\
\hline Lombardia & Lecco & 19.46 & 56.75 & 0.00 & 100 & 86 & 76 \\
\hline Lombardia & Lodi & 22.04 & 54.15 & 0.00 & 93 & 90 & 76 \\
\hline Lombardia & Mantova & 24.49 & 50.10 & 0.00 & 88 & 97 & 76 \\
\hline Lombardia & Milano & 39.92 & 80.13 & 3.11 & 25 & 14 & 32 \\
\hline Lombardia & Pavia & 24.93 & 57.33 & 1.18 & 86 & 84 & 59 \\
\hline Lombardia & Sondrio & 25.57 & 64.30 & 1.77 & 79 & 59 & 50 \\
\hline Lombardia & Varese & 28.87 & 62.92 & 0.73 & 66 & 64 & 70 \\
\hline Marche & Ancona & 36.59 & 59.63 & 0.00 & 40 & 78 & 76 \\
\hline Marche & Ascoli Piceno & 25.02 & 60.78 & 1.53 & 84 & 71 & 54 \\
\hline Marche & Macerata & 28.10 & 63.94 & 0.00 & 68 & 61 & 76 \\
\hline Marche & Pesaro_Urbino & 25.04 & 49.09 & 0.89 & 82 & 98 & 65 \\
\hline Molise & Campobasso & 27.72 & 57.48 & 4.27 & 70 & 83 & 26 \\
\hline Molise & Isernia & 41.77 & 72.57 & 0.00 & 22 & 27 & 76 \\
\hline Piemonte & Alessandria & 36.74 & 68.45 & 1.49 & 39 & 36 & 55 \\
\hline Piemonte & Asti & 31.43 & 71.56 & 3.30 & 56 & 32 & 28 \\
\hline Piemonte & Biella & 28.04 & 85.00 & 0.00 & 69 & 6 & 76 \\
\hline Piemonte & Cuneo & 20.90 & 48.48 & 1.64 & 95 & 100 & 52 \\
\hline Piemonte & Novara & 35.00 & 83.12 & 1.74 & 43 & 12 & 51 \\
\hline Piemonte & Torino & 34.70 & 79.74 & 1.95 & 44 & 17 & 45 \\
\hline Piemonte & $\begin{array}{l}\text { Verbano_Cusio_ } \\
\text { Ossola }\end{array}$ & 30.93 & 84.51 & 0.00 & 57 & 7 & 76 \\
\hline Piemonte & Vercelli & 30.19 & 67.84 & 1.83 & 63 & 40 & 49 \\
\hline Puglia & Bari & 37.54 & 65.79 & 4.08 & 33 & 52 & 27 \\
\hline Puglia & Brindisi & 46.48 & 68.04 & 82.05 & 6 & 38 & 4 \\
\hline Puglia & Foggia & 48.37 & 71.84 & 7.55 & 5 & 29 & 14 \\
\hline Puglia & Lecce & 44.43 & 71.70 & 5.30 & 11 & 31 & 17 \\
\hline Puglia & Taranto & 41.44 & 53.93 & 5.29 & 23 & 92 & 18 \\
\hline Sardegna & Cagliari & 41.81 & 91.48 & 2.31 & 21 & 4 & 40 \\
\hline Sardegna & Nuoro & 39.32 & 94.06 & 5.00 & 26 & 3 & 19 \\
\hline Sardegna & Oristano & 20.35 & 57.57 & 0.00 & 98 & 82 & 76 \\
\hline Sardegna & Sassari & 42.07 & 98.25 & 2.90 & 19 & 1 & 34 \\
\hline Sicilia & Agrigento & 35.05 & 59.55 & 4.86 & 42 & 79 & 23 \\
\hline Sicilia & Caltanissetta & 40.81 & 77.55 & 5.00 & 24 & 21 & 22 \\
\hline Sicilia & Catania & 44.82 & 56.65 & 38.54 & 10 & 87 & 12 \\
\hline Sicilia & Enna & 35.23 & 60.55 & 7.35 & 41 & 72 & 15 \\
\hline Sicilia & Messina & 33.98 & 67.96 & 4.42 & 49 & 39 & 25 \\
\hline Sicilia & Palermo & 42.50 & 65.87 & 84.58 & 16 & 51 & 2 \\
\hline Sicilia & Ragusa & 41.91 & 60.04 & 5.43 & 20 & 76 & 16 \\
\hline Sicilia & Siracusa & 42.48 & 75.27 & 79.03 & 17 & 24 & 6 \\
\hline
\end{tabular}


Table 20 (continued)

\begin{tabular}{|c|c|c|c|c|c|c|c|}
\hline Region & Province & OCI-Av & HOCI & LOCI & Rank-Av & Rank-HOCI & Rank-LOCI \\
\hline Sicilia & Trapani & 42.62 & 68.75 & 83.66 & 15 & 35 & 3 \\
\hline Toscana & Arezzo & 32.47 & 65.71 & 2.80 & 54 & 53 & 36 \\
\hline Toscana & Firenze & 34.20 & 63.20 & 1.29 & 48 & 63 & 57 \\
\hline Toscana & Grosseto & 36.97 & 62.50 & 2.88 & 37 & 67 & 35 \\
\hline Toscana & Livorno & 30.78 & 72.77 & 0.00 & 59 & 26 & 76 \\
\hline Toscana & Lucca & 24.03 & 70.75 & 0.00 & 90 & 33 & 76 \\
\hline Toscana & Massa_Carrara & 22.47 & 61.89 & 3.23 & 92 & 70 & 31 \\
\hline Toscana & Pisa & 33.96 & 62.64 & 2.31 & 50 & 66 & 39 \\
\hline Toscana & Pistoia & 34.60 & 66.90 & 2.49 & 46 & 46 & 38 \\
\hline Toscana & Prato & 44.07 & 66.21 & 5.00 & 12 & 50 & 19 \\
\hline Toscana & Siena & 33.01 & 57.63 & 0.00 & 52 & 81 & 76 \\
\hline $\begin{array}{l}\text { Trentino-Alto } \\
\text { Adige }\end{array}$ & Bolzano & 20.74 & 45.52 & 1.88 & 97 & 101 & 48 \\
\hline $\begin{array}{l}\text { Trentino-Alto } \\
\text { Adige }\end{array}$ & Trento & 24.70 & 55.90 & 0.60 & 87 & 88 & 71 \\
\hline Umbria & Perugia & 27.17 & 66.46 & 0.00 & 75 & 48 & 76 \\
\hline Umbria & Terni & 27.47 & 64.44 & 0.00 & 73 & 57 & 76 \\
\hline Valle d'Aosta & Aosta & 33.94 & 76.81 & 5.00 & 51 & 22 & 19 \\
\hline Veneto & Belluno & 19.66 & 67.75 & 1.55 & 99 & 41 & 53 \\
\hline Veneto & Padova & 25.65 & 65.65 & 0.00 & 78 & 54 & 76 \\
\hline Veneto & Rovigo & 24.94 & 57.24 & 0.00 & 85 & 85 & 76 \\
\hline Veneto & Treviso & 13.07 & 35.90 & 0.36 & 103 & 103 & 74 \\
\hline Veneto & Venezia & 26.03 & 60.41 & 0.76 & 76 & 73 & 68 \\
\hline Veneto & Verona & 32.69 & 60.07 & 2.11 & 53 & 75 & 43 \\
\hline Veneto & Vicenza & 20.85 & 48.80 & 0.74 & 96 & 99 & 69 \\
\hline
\end{tabular}

OCI-Av, HOCI, and LOCI represent index outcomes with the equally-weighted, highest and lowest OCI scores, respectively. Rank-Av, Rank-HOCI, and Rank-LOCI represent rankings with the equallyweighted, highest and lowest OCI scores, respectively 


\section{References}

Acciari, P., Polo, A., \& Violante, G. (2017). And yet, it moves': Inter-generational mobility in Italy. Mimeo NYU.

Acemoglu, D., De Feo, G., \& De Luca, G. D. (2020). Weak states: Causes and consequences of the Sicilian Mafia. Review of Economic Studies, 87(2), 537-581.

Acemoglu, D., Robinson, J. A., \& Santos, R. J. (2013). The monopoly of violence: Evidence from Colombia. Journal of the European Economic Association, 11, 5-44.

Agliardi, E., Agliardi, R., Pinar, M., Stengos, T., \& Topaloglou, N. (2012). A new country risk index for emerging markets: A stochastic dominance approach. Journal of Empirical Finance, 19(5), 741-761.

Agliardi, E., Pinar, M., \& Stengos, T. (2014). A sovereign risk index for the Eurozone based on stochastic dominance. Finance Research Letters, 11(4), 375-384.

Agliardi, E., Pinar, M., \& Stengos, T. (2015). An environmental degradation index based on stochastic dominance. Empirical Economics, 48(1), 439-459.

Albanese, J. S. (2015). Organized crime: From the mob to transnational organized crime. London: Routledge. https://doi.org/10.4324/9781315721477.

Alesina, A., Piccolo, S., \& Pinotti, P. (2019). Organized crime, violence, and politics. The Review of Economic Studies, 86(2), 457-499.

Alexeev, M., Janeba, E., \& Osborne, S. (2004). Taxation and evasion in the presence of extortion by organized crime. Journal of Comparative Economics, 32, 375-387.

Anselin, L., Cohen, J., Cook, D., Gorr, W., \& Tita, G. (2000). Spatial analyses of crime. In Duffee D. (Ed.), Criminal justice vol. 4, pp. 213-262.

Arvanitis, S., \& Topaloglou, N. (2017). Testing for prospect and Markowitz stochastic dominance efficiency. Journal of Econometrics, 198(2), 253-270.

Backhaus, J. (1979). Defending organized crime? A note. The Journal of Legal Studies, 8(3), 623-631.

Battisti, M., Bernardo, G., Konstantinidi, A., Kourtellos, A., \& Lavezzi, A. M. (2020). Socio-economic inequalities and organized crime: An empirical analysis. In D. Weisburd, E. Savona, B. Hasisi, \& F. Calderoni (Eds.), Understanding recruitment to organized crime and terrorism. Cham: Springer.

Battisti, M., Bernardo, G., Lavezzi, A. M., \& Maggio, G. (2019). Shooting down the price: Evidence from mafia homicides and housing market volatility. Working Paper series 19-05, Rimini Centre for Economic Analysis.

Battisti, M., Lavezzi, A. M., Masserini, L., \& Pratesi, M. (2018). Resisting the extortion racket: An empirical analysis. European Journal of Law and Economics, 46(1), 1-37.

Becker, G. S. (1968). Crime and punishment: An economic approach. Journal of Political Economy, 76(2), 169-217.

Becker, G. S., Murphy, K. M., \& Grossman, M. (2006). The market for illegal goods: The case of drugs. Journal of Political Economy, 114(1), 38-60.

Boeri, F., Di Cataldo, M., \& Pietrostefani, E. (2019). Out of the darkness: Re-allocation of confiscated real estate mafia assets. Available at SSRN. https://ssrn.com/abstract=3488626.

Buchanan, J. M. (1973). A defense of organized crime? In S. Rottenberg (Ed.), The economics of crime and punishment. American Enterprise Institute.

Buonanno, P., \& Pazzona, M. (2014). Migrating mafias. Regional Science and Urban Economics, 44, $75-81$

Caglayan, M., Flamini, A., \& Jahanshahi, B. (2018). Organised crime and technology. DEM Working Papers Series, n. 143, Università di Pavia.

Calamunci, F., \& Drago, F. (2020). The economic impact of organized crime infiltration in the legal economy: Evidence from the judicial administration of organized crime firms. Italian Economic Journal, 6, 275-297.

Calderoni, F. (2011). Where is the mafia in Italy? Measuring the presence of the mafia across Italian provinces. Global Crime, 12(1), 41-69.

Calderoni, F. (2014). Measuring the presence of the mafias in Italy. In S. Caneppele \& F. Calderoni (Eds.), Organized crime, corruption and crime prevention (pp. 239-249). New York, NY: Springer.

Capuano, C., \& Giacalone, M. (2018). Measuring organized crime: Statistical indicators and economic aspects. Economics and Econometrics Research Institute Research Paper Series, n. 11, Brussels. 
Carraro, C., Campagnolo, L., Eboli, F., Giove, S., Lanzi, E., Parrado, R., et al. (2013). The FEEM sustainability index: An integrated tool for sustainability assessment. In M. G. Erechtchoukova, P. A. Khaiter, \& P. Golinska (Eds.), Sustainability appraisal: Quantitative methods and mathematical techniques for environmental performance evaluation (pp. 9-32). Berlin: Springer, Berlin Heidelberg.

Catino, M. (2014). How do mafia as organize? Conflict and violence in three mafia organizations. European Journal of Sociology, 55(2), 177-220. https://doi.org/10.1017/S0003975614000095.

Centorrino, M., \& Ofria, F. (2008). Criminalità organizzata e produttività del lavoro nel Mezzogiorno: un'applicazione del modello Kaldor-Verdoorn. Rivista Economica del Mezzogiorno, 1, 163-189.

Centorrino, M., \& Signorino, G. (1993). Criminality and models of local economy. In S. Zamagni (Ed.), Illegal markets and mafias. The economy of organised crime. Bologna: Il Mulino.

Centorrino, M., \& Signorino, G. (1997). Macroeconomy of the mafia. Roma: La Nuova Italia Scientifica.

Cracolici, M. F., \& Uberti, T. E. (2009). Geographical distribution of crime in Italian provinces: A spatial econometric analysis. Jahrbuch für Regionalwissenschaft, 29, 1-28.

Dal Bó, E., Dal Bó, P., \& Di Tella, R. (2006). "Plata o Plomo?”: Bribe and punishment in a theory of political influence. American Political Science Review, 100(1), 41-53.

Dal Bó, E., \& Di Tella, R. D. (2003). Capture by threat. Journal of Political Economy, 111, 1123-1154.

Daniele, V. (2009). Organized crime and regional development. A review of the Italian case. Trends in Organized Crime, 12(3-4), 211-234.

Daniele, G., \& Dipoppa, G. (2017). Mafia, elections and violence against politicians. Journal of Public Economics, 154, 10-33.

Daniele, G., \& Geys, B. (2015). Organised crime, institutions and political quality: Empirical evidence from Italian municipalities. Economic Journal, 125, 233-255.

Daniele, V., \& Marani, U. (2011). Organized crime, the quality of local institutions and FDI in Italy: A panel data analysis. European Journal of Political Economy, 27, 132-142.

De Feo, G., \& De Luca, G. D. (2017). Mafia in the ballot box. American Economic Journal: Economic Policy, 9(3), 134-167.

Decancq, K., \& Lugo, M. A. (2013). Weights in multidimensional indices of wellbeing: An overview. Econometric Reviews, 32(1), 7-34.

Di Cataldo, M., \& Mastrorocco, N. (2020). Organised crime, captured politicians, and the allocation of public resources. University Ca' Foscari of Venice, Dept. of Economics Research Paper Series No. 04/WP/2020. Available at SSRN. https://ssrn.com/abstract=3599850.

Dugato, M., Calderoni, F., \& Campedelli, G. M. (2020). Measuring organised crime presence at the municipal level. Social Indicator Research, 147, 237-261.

Dugato, M., De Simoni, M., \& Savona, E. U. (2014). Measuring OC in Latin America. A methodology for developing and validating scores and composite indicators at national and subnational level. Aguascalientes, Mexico: INEGI/UNODC. Retrieved from http://www.transcrime.it/pubblicazioni/ measuring-oc-in-latin-america/.

Europol. (2013). Europol Review 2013. Available via: https://data.europa.eu/euodp/en/data/dataset/europ ol-review-2013/resource/e017b72a-259e-42f7-816a-64a724d8e4e2.

Fabrizi, M., Malaspina, P., \& Parbonetti, A. (2019). The economic consequences of criminal firms. Presented at the 2019 global issues in accounting conference at Chicago Booth, Available at SSRN. https://ssrn.com/abstract=3444839.

Fang, Y., \& Post, T. (2017). Higher-degree stochastic dominance optimality and efficiency. European Journal of Operational Research, 261(3), 984-993.

Felice, E. (2018). The socio-institutional divide: Explaining Italy's long-term regional differences. The Journal of Interdisciplinary History, 49(1), 43-70.

Foster, J., McGillivray, M., \& Seth, S. (2013). Composite indices: Rank robustness, statistical association, and redundancy. Econometric Reviews, 32(1), 35-56.

Ganau, R., \& Rodríguez-Pose, A. (2018). Industrial clusters, organized crime, and productivity growth in Italian SMEs. Journal of Regional Science, 58(2), 363-385.

Gonzalez-Ruiz, S., \& Buscaglia, E. (2002).How to design a national strategy against organized crime in the framework of the United Nations' Palermo convention. The Fight against Organized Crime (Lima, United Nations International Drug Control Programme, 2002), pp. 23-26.

Greco, S., Ishizaka, A., Tasiou, M., \& Torrisi, G. (2019). On the methodological framework of composite indices: A review of the issues of weighting, aggregation, and robustness. Social Indicators Research, 141, 61-94. 
ISTAT (2010). B. Indicatori di contesto chiave e variabili di rottura. September 2010. http://www.istat.it/ ambiente/contesto/infoterr/azioneB.html\#tema.

Kugler, M., Verdier, T., \& Zenou, Y. (2005). Organized crime, corruption and punishment. Journal of Public Economics, 89(8-9), 1639-1663.

Kuosmanen, T. (2004). Efficient diversification according to stochastic dominance criteria. Management Science, 50, 1390-1406.

Lavezzi, A. M. (2008). Economic structure and vulnerability to organised crime: Evidence from Sicily. Global Crime, 3(9), 198-220.

Levitt, S. D., \& Venkathesh, S. A. (2000). An economic analysis of a drug-selling gang's finances. Quarterly Journal of Economics, 115(3), 755-789.

Linton, O., Post, T., \& Whang, Y.-J. (2014). Testing for the stochastic dominance efficiency of a given portfolio. Econometrics Journal, 17, 59-74.

Marselli, R., \& Vannini, M. (1997). Estimating a crime equation in the presence of organized crime: Evidence from Italy. International Review of Law and Economics, 17(1), 89-113.

McGillivray, M. (2005). Measuring non-economic well-being achievement. Review of Income and Wealth, 51(2), 337-364.

Mehdi, T. (2019). Stochastic dominance approach to OECD's better life index. Social Indicators Research, 143(3), 917-954.

Mennella, A. (2011). La criminalità organizzata quale intermediario nel mercato del lavoro. Argomenti, 31, 65-105.

Messner, S. F., Anselin, L., Baller, R. D., Hawkins, D. F., Deane, G., \& Tolnay, S. E. (1999). The spatial pattering of county homicide rates: An application of explanatory spatial data analysis. Journal of Quantitative Criminology, 15(4), 423-450.

Ministry Interior, Italia. (2007). Rapporto sulla criminalità e la Sicurezza in Italia. Available via: https ://www1.interno.gov.it/mininterno/export/sites/default/it/assets/files/14/0900_rapporto_criminalit a.pdf.

Neanidis, K. C., Rana, M. P., \& Blackburn, K. (2017). An empirical analysis of organized crime, corruption and economic growth. Annals of Finance, 13(3), 273-298.

Nifo, A., \& Vecchione, G. (2014). Do Institutions play a role in skilled migration? The case of Italy, Regional Studies, 48(10), 1628-1649. https://doi.org/10.1080/00343404.2013.835799.

OECD. (2008). Handbook on constructing composite indicators: Methodology and user guide. Paris: OECD Publishing.

Ogwang, T., \& Abdou, A. (2003). The choice of principal variables for computing some measures of human well-being. Social Indicators Research, 64(1), 139-152.

Peri, G., (2004). Socio-cultural variables and economic success: Evidence from Italian provinces 1951-1991. The B.E. Journal of Macroeconomics. Topics in Macroeconomics 4, article 12.

Pinar, M. (2015). Measuring world governance: Revisiting the institutions hypothesis. Empirical Economics, 48(2), 747-778.

Pinar, M., Cruciani, C., Giove, S., \& Sostero, M. (2014). Constructing the FEEM sustainability index: A Choquet integral application. Ecological Indicators, 39, 189-202.

Pinar, M., Milla, J., \& Stengos, T. (2019). Sensitivity of university rankings: Implications of stochastic dominance efficiency analysis. Education Economics, 27(1), 75-92.

Pinar, M., Stengos, T., \& Topaloglou, N. (2013). Measuring human development: A stochastic dominance approach. Journal of Economic Growth, 18(1), 69-108.

Pinar, M., Stengos, T., \& Topaloglou, N. (2017). Testing for the implicit weights of the dimensions of the Human Development Index using stochastic dominance. Economics Letters, 161, 38-42.

Pinar, M., Stengos, T., \& Yazgan, M. E. (2015). Measuring human development in the MENA region. Emerging Markets Finance and Trade, 51(6), 1179-1192.

Pinotti, P. (2011). The economic consequences of organized crime: Evidence from Southern Italy. Bank of Italy.

Pinotti, P. (2015a). The economic costs of organised crime: Evidence from Southern Italy. The Economic Journal, 125(586), F203-F232.

Pinotti, P. (2015b). The causes and consequences of organised crime: Preliminary evidence across countries. The Economic Journal, 125(586), F158-F174.

Pinotti, P. (2020). The credibility revolution in the empirical analysis of crime. Italian Economic Journal, 6, 207-220.

Post, T. (2003). Empirical tests for stochastic dominance efficiency. Journal of Finance, 58, 1905-1932. 
Post, T., \& Poti, V. (2017). Portfolio analysis using stochastic dominance, relative entropy and empirical likelihood. Management Science, 63(1), 153-165.

Post, T., \& Versijp, P. (2007). Multivariate tests for stochastic dominance efficiency of a given portfolio. Journal of Financial and Quantitative Analysis, 42, 489-516.

Ram, R. (1982). Composite indices of physical quality of life, basic needs fulfilment, and income. A 'principal component' representation. Journal of Development Economics, 11(2), 227-247.

Ray, A. K. (2008). Measurement of social development: An international comparison. Social Indicators Research, 86(1), 1-46.

Roman, D., Darby-Dowman, K., \& Mitra, G. (2006). Portfolio construction based on stochastic dominance and target return distributions. Mathematical Programming, 108, 541-569.

Rose-Ackerman, S., \& Palifka, B. J. (2018). Corruption, organized crime, and money laundering. In K. Basu \& T. Cordella (Eds.), Institutions, governance and the control of corruption., International Economic Association Series Cham: Palgrave Macmillan.

Sansò-Rubert Pascual, D. (2017). Democracias bajo presión: Estado, Fuerzas Armadas y Crimen Organizado en América Latina: ¿Éxito o fracaso de la estrategia de contención militar? Madrid: Dykinson.

Savona, E. U., Dugato, M., \& Garofalo, L. (2012). A framework for the quantification of organized crime and assessment of availability and quality of relevant data in three selected countries of Latin America and the Caribbean. Aguascalientes: INEGI/UNODC.

Scaillet, O., \& Topaloglou, N. (2010). Testing for stochastic dominance efficiency. Journal of Business \& Economic Statistics, 28(1), 169-180.

Shelling, T. (1971-1984a). What is the Business of Organized Crime? In Shelling, T. (Ed.), Choice and consequences. Harvard University Press, Cambridge.

Shelling, T. (1984). Economics and criminal Enterprise. In T. Shelling (Ed.), Choice and consequences (pp. 158-178). Cambridge, MA: Harvard University Press.

Singh, R. K., Murty, H. R., Gupta, S. K., \& Dikshit, A. K. (2012). An overview of sustainability assessment methodologies. Ecological Indicators, 15(1), 281-299.

Smits, J., \& Steendijk, R. (2015). The international wealth index (IWI). Social Indicators Research, $122(1), 65-85$.

Torres-Preciado, V. H., Polanco-Gaytán, M., \& Tinoco-Zermeño, M. A. (2017). Crime and regional economic growth in Mexico: A spatial perspective. Papers in Regional Science, 96, 477-494.

UNODC. (2010). Promoting health, security and justice. (https://www.unodc.org/documents/frontpage/ UNODC_Annual_Report_2010_LowRes.pdf).

van Dijk, J. (2007). Mafia markers: Assessing organized crime and its impact upon societies. Trends in Organized Crime, 10(4), 39-56.

Wendling, Z. A., Emerson, J. W., de Sherbinin, A., Esty, D. C., et al. (2020). 2020 Environmental performance index. New Haven, CT: Yale Center for Environmental Law \& Policy. Available via: https:// epi.yale.edu/downloads/epi2020technicalappendix20200604.pdf.

Publisher's Note Springer Nature remains neutral with regard to jurisdictional claims in published maps and institutional affiliations. 